FUNDAÇÃO UNIVERSIDADE FEDERAL DO TOCANTINS - UFT CAMPUS UNIVERSITÁRIO DE PALMAS MESTRADO PROFISSIONAL EM GESTÃO DE POLÍTICAS PÚBLICAS

NADIA BECMAM LIMA

INSTITUCIONALIZAÇÃO DA GESTÃO SUSTENTÁVEL NO TRIBUNAL DE JUSTIÇA DO TOCANTINS

PALMAS 2018 
NADIA BECMAM LIMA

\title{
INSTITUCIONALIZAÇÃO DA GESTÃO SUSTENTÁVEL NO TRIBUNAL DE JUSTIÇA DO TOCANTINS
}

\begin{abstract}
Dissertação apresentada ao Mestrado Profissional em Gestão de Políticas Públicas (GESPOL), da Universidade Federal do Tocantins, como requisito parcial para obtenção do título de Mestre em Gestão de Políticas Públicas. Linha de Pesquisa: Educação, Ciência e Tecnologia e Desenvolvimento Territorial. Orientadora: Prof ${ }^{a}$. Dra. Lia Azevedo Almeida
\end{abstract}

\section{PALMAS}


Dados Internacionais de Catalogação na Publicação (CIP) Sistema de Bibliotecas da Universidade Federal do Tocantins

LT32i Lima, Nadia

Instinueionaliaçio da Cestâo Sustentivel no Tribunal de Justiça do Tocantins. / Nadia Lima. - Pahns, TO, 2018

$133 t$

Dissertaçăo (Mestrado Proflasional) - Universidude Federal do Tocantin - Cimpuas Universitáno de Palmas - Curso de Pós-Craduaçăo (Mestrado) Protasional em Gestato de Politicas Pablicas, 201 Orientadoen : Lin Almeida

1. Gestibo Sustentivel. 2. Administraçăo Públice. 3. Poder Judiciario. 4.

CDD 350

TODOS OS DIREITOS RESERKXDOS - A reproduçlo total ou pancial, de qualquer Soma ou por qualquer meio deste documento é autorizudo des de que citada a fonte. A violacilo dos dreitos do autor (Lei no 9.610989 ) é crime estabelecido pelo artigo 184

Mathrado pelo sistema de geracilo sutomitica de fieha catalogrifiea du UFT com o. 


\title{
NADIA BECMAN LIMA
}

\section{INSTITUCIONALIZAÇÃO DA GESTÃO SUSTENTÁVEL NO TRIBUNAL DE JUSTIÇA DO TOCANTINS}

\author{
Dissertação apresentada ao Curso de Mestrado \\ Profissional em Gestão de Políticas Públicas da \\ Universidade Federal do Tocantins para obtenção do \\ título de mestre. \\ Orientadora: Profa. Dra. Lia de Azevedo Almeida
}

Aprovada em 24/11/2018.

BANCA EXAMINADORA:

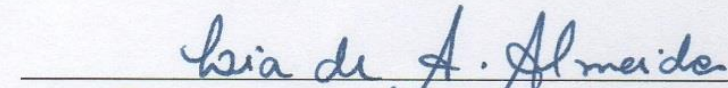

Profa. Dra. Lia de Azeredo Almeida (Orientadora)
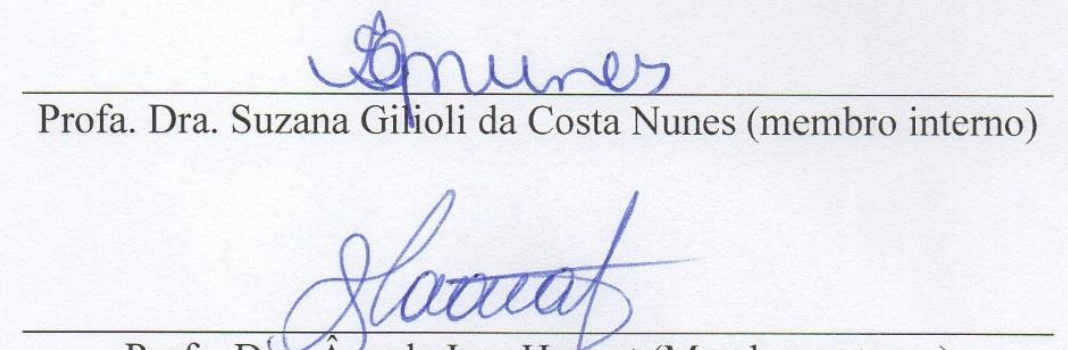

Profa. Dra. Ângela Issa Haonat (Membro externo) 
Aos meus pais, Cícero Ferreira Lima e Jandira Becmam Lima 


\section{AGRADECIMENTOS}

A Deus, por ter me concedido sabedoria, resiliência e por me manter firme na conclusão de mais uma etapa da minha educação;

À minha família, meus pais Cícero e Jandira, meus irmãos Adriano e Allan, meus sobrinhos Fellipe e Ana Flávia e minhas cunhadas Daniela e Mariana pelo apoio e pela compreensão nos momentos de stress e ausência ao longo destes 2 anos, meu muito obrigada;

A minha orientadora, Prof. Dra. Lia Azevedo Almeida, por ter me conduzido até aqui com paciência e ensinamentos no qual seguirei como parâmetro se concretizar os planos de me imbuir na vida acadêmica na condição de docente;

Aos professores do Programa GESPOL, por compartilharem suas sabedorias, que tanto agreguei em minha vida;

Aos meus colegas do mestrado, com quem partilhei minhas sextas e sábados por 1 ano no período que tivemos aulas, cuja presença intermediada por aplicativo de celular se manteve firme ao longo da trajetória em que tivemos que caminhar sozinhos, terão minha admiração e respeito;

Aos colegas da Procuradoria Jurídica da Fundação UNIRG, que sempre que precisei não negaram auxílio e concederam o suporte necessário;

Aos meus amigos que tiveram comigo me conduzindo desde a confecção do projeto submetido ao processo seletivo do mestrado, até aqui, e a todos os outros que sempre me estendem a mão, me apoiam e torcem pelas minhas vitórias, muitíssimo obrigada. 
"Aqueles que contemplam a beleza da terra, encontram reservas de força que irão perdurar enquanto a vida durar. Há algo infinitamente curativo nos refrões repetidos da natureza: a garantia de que o amanhecer vem depois da noite e a primavera depois do inverno."

Rachel Carson 


\section{RESUMO}

Assuntos relacionados à preservação do meio ambiente tem sido uma preocupação internacional, visto o impacto que a malversação do uso dos recursos naturais tem causado à natureza. Os debates a respeito do assunto que envolveram chefes de Estados, cientistas e sociedade civil, trouxe como consequência a necessidade e o comprometimento de se buscar mecanismos para reduzir a degradação ambiental. O Estado, no seu papel fundamental a respeito do desenvolvimento sustentável, pautado no tripé econômico, social e ambiental, implementou políticas públicas que visassem a conscientização e importância de se preservar o meio ambiente, instituindo leis e disseminando programas imbuídos de ações que visem uma gestão sustentável. Nesta seara, o Poder Judiciário implementou mecanismos e ferramentas de cunho obrigatório a todos os Tribunais do país em prol do efetivo cumprimento das exigências voltadas para as atividades sustentáveis. Deste modo, esta pesquisa propôs a análise da institucionalização da gestão sustentável no Tribunal de Justiça do Estado do Tocantins, buscando-se caracterizar os instrumentos de gestão socioambiental do Tribunal, identificar a percepção dos servidores sobre a institucionalização da gestão socioambiental, assim como as potencialidades e deficiências no processo. Quanto à metodologia tratou-se de uma pesquisa quali-quantitativa, com objetivo exploratório e descritivo, para tanto, adotou-se como procedimentos metodológicos, pesquisa bibliográfica e documental e aplicação de questionários à comissão socioambiental e servidores com cargos de chefias do TJTO, configurando-se em um estudo de caso que possibilitou propor melhorias no processo de institucionalização da gestão sustentável do TJ/TO com base nas deficiências detectadas. Com os resultados, foi possível verificar que a institucionalização da gestão sustentável no órgão, com a ocorrência de práticas socioambientais ligadas a preservação dos bens e recursos naturais e gestão de resíduos gerados. Averiguando-se pontos positivos principalmente no que se refere à implantação das exigências normativas imposta pelo CNJ e pontos negativos no tocante aos aspectos ligados à sensibilização e capacitação dos servidores. Assim, com base nas limitações vislumbradas, foi possível sugerir melhorias ao processo de institucionalização da gestão socioambiental, com o objetivo de eliminá-las e maximizar as potencialidades detectadas, para que se torne plenamente efetiva e se possa fortalecer o processo de institucionalização da gestão sustentável.

Palavras-chave: Gestão Sustentável. Administração Pública. Poder Judiciário. Tribunal de Justiça do Tocantins. 


\begin{abstract}
Issues related to the preservation of the environment have been an international concern, given the impact that malpractice of the use of natural resources has caused to nature. Discussions on the subject involving heads of States, scientists and civil society have brought about the need and commitment to seek mechanisms to reduce environmental degradation. The State, in its fundamental role regarding sustainable development, based on the economic, social and environmental tripod, implemented public policies aimed at raising awareness and importance of preserving the environment, establishing laws and disseminating programs imbued with actions meant at managing sustainable development. In this area, the Judiciary Power has implemented mechanisms and tools that are mandatory for all Courts in the country in order to effectively meet the requirements for sustainable activities. Thus, this research proposed the analysis of the institutionalization of sustainable management in the Court of Justice of the State of Tocantins (TJTO), seeking to characterize the instruments of social and environmental management of the Court, to identify the perception of the employees about the institutionalization of socio-environmental management, as well as the potentialities and deficiencies in the process. The methodology was a qualitative-quantitative research, with an exploratory and descriptive objective. To obtain this information, were adopted methodological procedures, bibliographical and documentary research and application of questionnaires to the socio-environmental commission and servers with leadership positions of TJTO, turning into a case study that made it possible to propose improvements in the process of institutionalizing the sustainable management of the TJ/TO based on the deficiencies detected. With the results, it was possible to verify that the institutionalization of the sustainable management in the organ, with the occurrence of socio environmental practices linked to the preservation of the assets and natural resources and generated waste management. Finding positive points mainly regarding the implementation of the regulatory requirements imposed by the $\mathrm{CNJ}$ and negative points regarding the aspects related to the awareness and qualification of the servers. Thus, based on the perceived limitations, it was possible to suggest improvements to the process of institutionalization of social and environmental management, with the objective of eliminating them and maximizing the potentialities detected, so that it becomes fully effective and the process of institutionalization of sustainable management can be strengthened .
\end{abstract}

Keywords: Sustainable Management. Public Administration. Judicial Power. Court of Justice of the State of Tocantins. 


\section{LISTA DE FIGURAS}

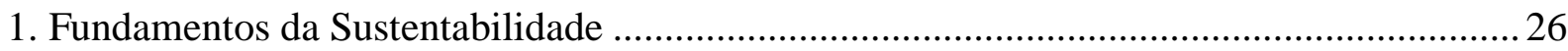

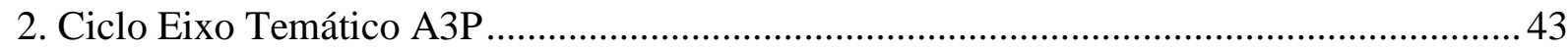

3. Passos para Construção do Plano de Logística Sustentável ............................................... 49

4. Relatório Socioambiental do Conselho Nacional de Justiça ................................................55

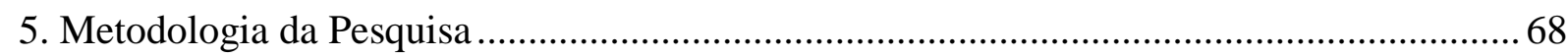




\section{LISTA DE GRÁFICOS}

1. Normativos que Orientam Implantação Práticas Ambientais.............................................. 89

2. Eficácia Disponibilização das Informações Comissão Socioambiental ............................... 97

3. Percentual de Adesão dos Agentes às Práticas Ambientais no TJTO ................................. 98

4. Dificuldades para Implantação de Práticas Socioambientais nas TJTO............................... 99

5. Ações Instrumentos Estratégicas das Práticas Socioambientais......................................... 100

6. Ações Praticadas e Implementadas de Acordo com a Comissão ........................................ 105

7. Ações Praticadas e Implementadas de Acordo com os Servidores ..................................... 106

8. Ações Praticadas e Implementadas de Acordo com a Comissão ....................................... 108

9. Ações Praticadas e Implementadas de Acordo com os Servidores .................................... 108 


\section{LISTA DE TABELAS}

1. Redução Emissão de Gases no Período de 2005 a 2012 ...................................................... 38

2. Resultado dos Questionários - Temática Socioambiental................................................ 88

3. Resultado dos Questionários - Meio de Divulgação de Práticas e Normativos Socioambientais 95

4. Uso Racional de Recursos Naturais e bens Públicos - Consumo Energia Elétrica ............ 102

5. Uso Racional de Recursos Naturais e Bens Públicos - Consumo Água ........................... 102

6. Uso Racional de Recursos Naturais e Bens Públicos - Consumo Papel ............................ 103

7. Uso Racional de Recursos Naturais e Bens Públicos - Consumo Copos Plásticos ........... 104

8. Gestão Adequada de Resíduos Gerados - Coleta Seletiva ................................................ 106

9. Gestão Adequada de Resíduos Gerados - Gestão de Resíduos Perigosos ......................... 106 


\section{LISTA DE QUADROS}

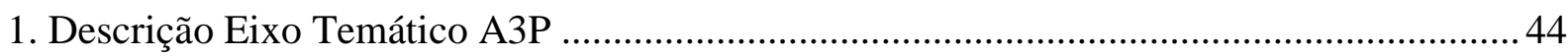

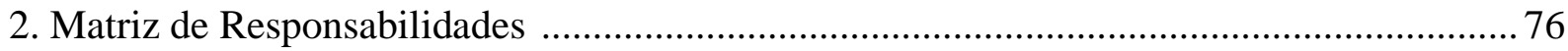

3. Resultado Gestão Materiais Consumo Papel ...................................................................... 77

4. Resultado Gestão Materiais Consumo Copos Descartáveis ............................................... 77

5. Resultado Gestão Materiais Consumo Água Engarrafada .................................................. 78

6. Gestão de Impressão de Documentos e Equipamentos Instalados ...................................... 79

7. Gestão de Consumo de Gasto com Energia Elétrica .......................................................... 79

8. Gestão do Consumo de Gasto com Água e Esgoto ............................................................ 70

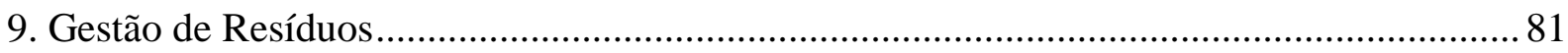

10. Gestão de Qualidade de Vida no Ambiente de Trabalho ................................................... 81

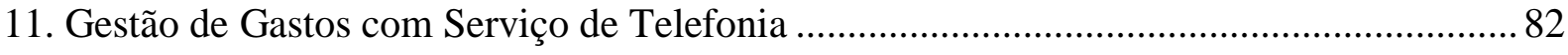

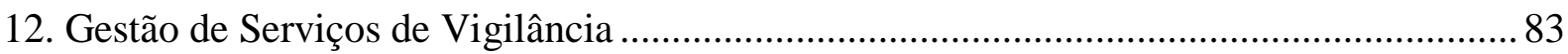

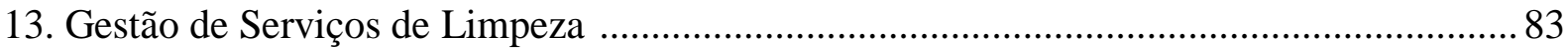

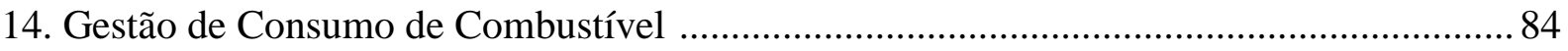

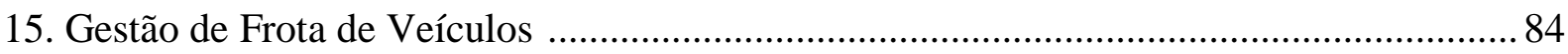

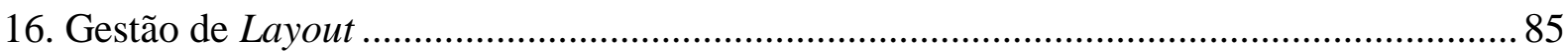

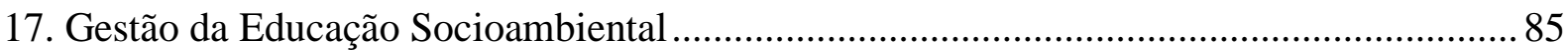

18. Potencialidades e Deficiência na Gestão Sustentável no TJTO ...................................... 119 


\section{LISTA DE ABREVIATURAS E SIGLAS}

Agenda Ambiental na Administração Pública - A3P

Conselho Nacional de Justiça - CNJ

Constituição Federal - CF

Ministério do Meio Ambiente - MMA

Organização das Nações Unidas - ONU

Plano de Logística Sustentável - PLS

Plano Nacional do Meio Ambiente - PNMA

Política de Educação Ambiental - PEA

Política Nacional de Resíduos Sólidos - PNRS

Política Nacional sobre Mudança do Clima - PNMC

Programa das Nações Unidas para o Meio Ambiente - PNUMA

Tribunal de Justiça do Estado do Tocantins - TJTO

Escola Superior da Magistratura - ESMAT 


\section{SUMÁRIO}

1. INTRODUÇÃ

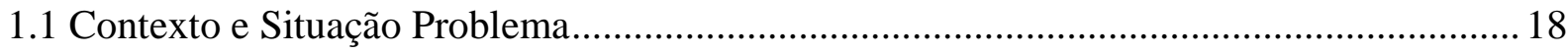

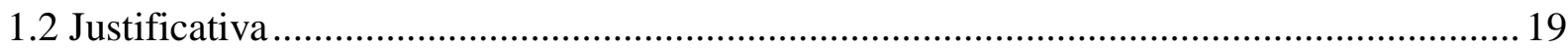

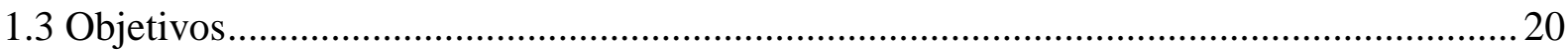

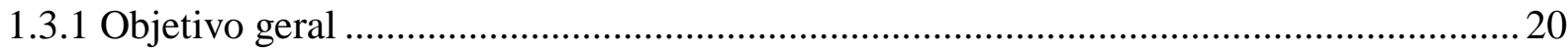

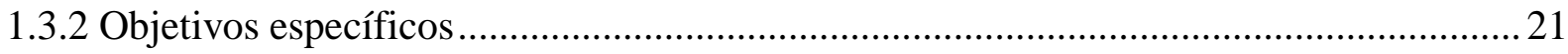

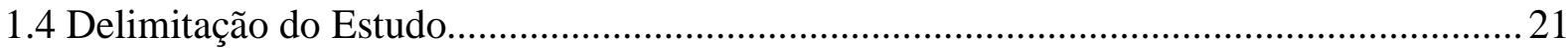

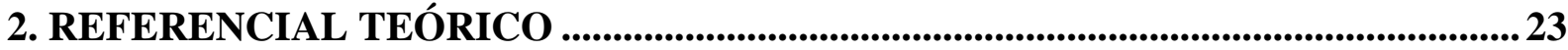

2.1 Conceitos e Discursos sobre Desenvolvimento Sustentável .........................................23

2.1.1 A gestão socioambiental: principais aspectos conceituais ..........................................28

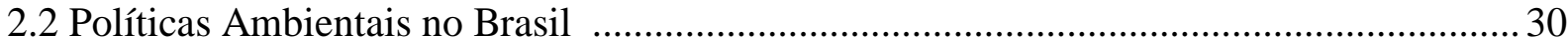

2.2.1 Aspectos conceituais sobre políticas públicas .............................................................. 31

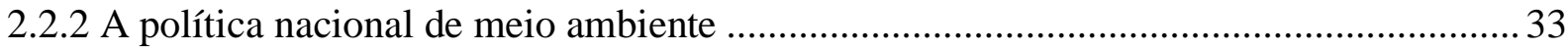

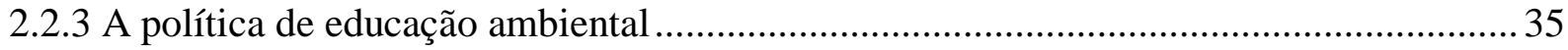

2.2.4 A política nacional de mudança de clima ...................................................................... 37

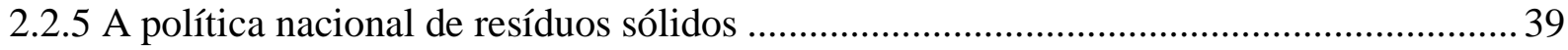

2.3 Instrumentos de Gestão Socioambiental na Administração Pública ................................. 41

2.3.1 O programa agenda ambiental na Administração Pública - A3P .................................. 41

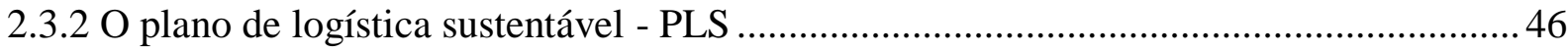

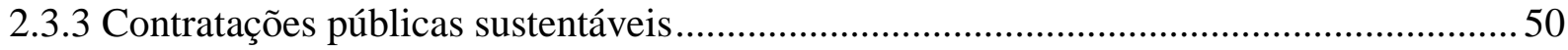

2.4. Instrumentos de Gestão Socioambiental no Poder Judiciário ..........................................52

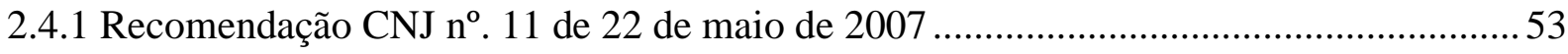

2.4.2 Recomendação CNJ no. 27 de 16 de dezembro de 2009 ...............................................56

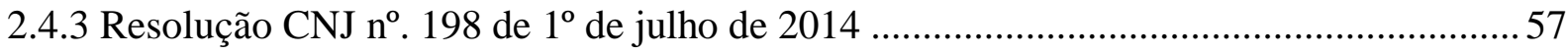

2.4.4 Resolução CNJ n ${ }^{\circ} .201$ de 3 de março de 2015 ............................................................. 57

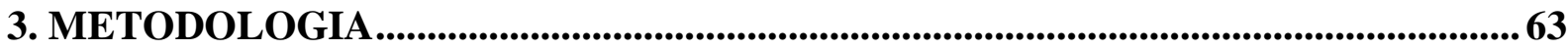

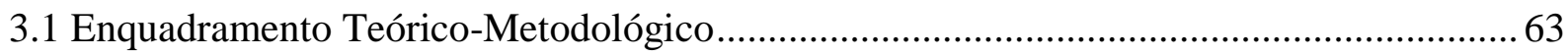

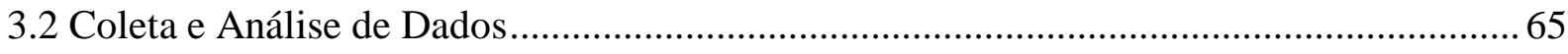

4. ANÁLISE DOS RESULTADOS E DISCUSSÃO ......................................................69

4.1 Contextualização do Tribunal de Justiça do Tocantins ........................................................ 69

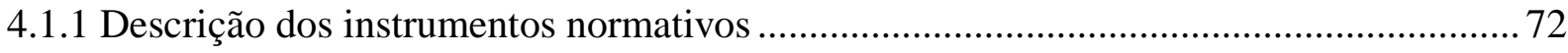

4.1.1.1 Resolução nº. 22/2015 - Institui Núcleo de Gestão Socioambiental do Poder Judiciário

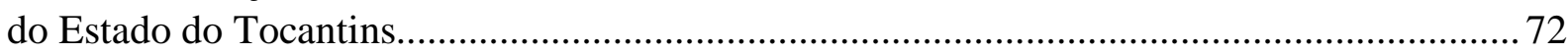


4.1.1.2 Portaria nº 3943/2015 - Institui Comissão Gestora do Plano de Logística Sustentável do Poder Judiciário do Estado do Tocantins ............................................................................. 73

4.2 Análise do Plano de Logística Sustentável e Relatórios de Desempenho.......................... 74

4.3 Análise dos Dados Obtidos a Partir da Aplicação do Questionário .................................. 87

4.3.1 GT 1 - Conhecimento da temática e legislação ambiental ............................................ 88

4.3.2 GT 2 - A comissão do núcleo de gestão socioambiental e a sua relação com a instituição

4.3.3 GT 3 - A questão socioambiental e a institucionalização no TJTO ............................. 93

4.3.4 GT 4 - Sensibilização e capacitação socioambiental TJTO ......................................... 94

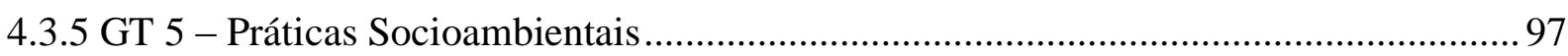

4.4 Discussão do Processo de Institucionalização da Gestão Socioambiental no TJTO

4.5 Proposta de Melhorias para a Gestão Socioambiental no Tribunal de Justiça do Tocantins 120

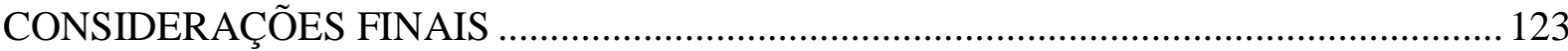

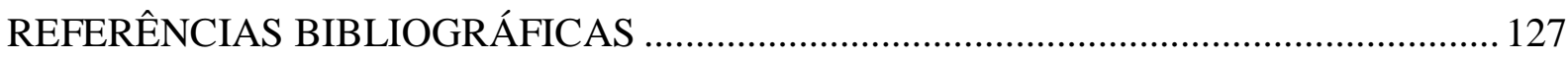

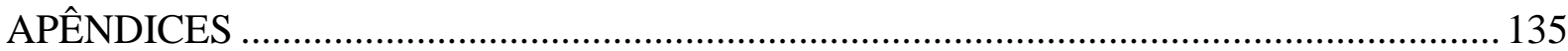




\section{INTRODUÇÃO}

A crise ambiental é objeto de discussão de todas as nações, tanto que a sociedade mundial tem se dedicado a encontrar mecanismos quanto à forma de combater e ou inibir ações que causem a sua degradação, de modo a evitar os inúmeros malefícios que os desgastes dos recursos naturais podem causar ao meio ambiente e às vidas humanas.

Os países passaram a debater a respeito da forma como o modo de produção e as atividades humanas estavam impactando o meio ambiente, o que ocasionou na promoção de eventos com a participação de chefes de Estados, organizações civis e cidadãos interessados em discutir e promover estratégias que permitissem o desenvolvimento econômico sem comprometer o uso dos recursos naturais (BARBIERI, 2007).

Defender e melhorar o meio ambiente para as atuais e futuras gerações se tornou uma meta fundamental, o que demonstra que a questão ambiental é um dos graves problemas a ser tratado na atualidade passando a ser uma questão social, demandando do poder público, promoção de políticas públicas que visem amenizar ou diminuir os impactos que as ações humanas vêm causando ao meio ambiente (COMISSÃO DESENVOLVIMENTO HUMANO, 1988).

O Estado possui um papel fundamental no desenvolvimento de mecanismos que possibilitem a inserção no âmbito social e econômico da conscientização e importância de se preservar o meio ambiente, visto que tem como aliado para a fomentação de suas ações o uso da força normativa, como meio para se fazer cumprir as determinações impostas pelo ordenamento jurídico, de modo a implementar, executar e avaliar programas propostos para consecução de um meio ambiente ecologicamente equilibrado.

Consciente da demanda social e do papel preponderante do poder público de implementação de ações, de tomada de decisões e disseminação de boas práticas, a Constituição Cidadã de 1988, designou que compete ao próprio poder público e à coletividade o dever de promover a defesa e preservação do meio ambiente, visto que "todos tem direito ao gozo do meio ambiente ecologicamente equilibrado, considerado como bem de uso comum do povo e essencial à qualidade de vida saudável” (BRASIL, 1988, Art. 225).

O desenvolvimento sustentável passou a ser questão de ordem pública, adquiriu caráter político-normativo, pautado no tripé: socialmente justo, economicamente viável e ecologicamente equilibrado (BURSZTYN; BURSZTYN, 2006) e segundo Leff (2012, p. 
45), "a sustentabilidade passa a ser um objetivo que supera as capacidades das ciências, para se converter num projeto político mediante a constituição de atores sociais movidos pelo mesmo propósito", pensadas na preservação das necessidades presentes, sem que se comprometa as necessidades das futuras gerações (ORGANIZAÇÃO DA NAÇÕES UNIDAS, 1987).

A Administração Pública imbuída de seu papel tem promovido programas e ações que visam incentivar a produção e o consumo sustentável de bens e serviços, estimulando a mudança de atitude de seus agentes e gestores, com o fito de incorporarem uma gestão socioambiental no serviço público, cobrando e exigindo de seus órgãos e instituições implementação de práticas de sustentabilidade que minimizem os danos causados ao meio ambiente.

O Estado, como grande consumidor de bens e serviços, responsável pelo desenvolvimento das políticas públicas, inseriu no ordenamento jurídico normas que ensejassem a prática de atividades pautadas no desenvolvimento sustentável, como o Política Nacional do Meio Ambiente - PNMA (1981), Política de Educação Ambiental PEA (1999), Política Nacional sobre Mudança do Clima - PNMC (2009) e Política Nacional de Resíduos Sólidos - PNRS (2010).

Mas a preocupação com a preservação do meio ambiente, por parte da Administração Pública, não se restringiu ao cunho normativo, visto que buscou desenvolver práticas sustentáveis que servissem de exemplos a serem disseminados, como o programa de instituição da Agenda Ambiental na Administração Pública - A3P (1999), do Plano de Logística Sustentável - PLS (2012) e das Compras Verdes (2010) baseado em procedimento licitatório, todos os programas voltados para mecanismos que auxiliam na revisão de práticas no serviço público que busquem a preservação do meio ambiente.

Ponderando a influência que a atividade governamental exerce sobre as atividades econômicas e sociais e a relevância de se servir de ações desenvolvidas para a conscientização a respeito de questões socioambientais, o Poder Judiciário não ficou inerte quanto ao seu papel social em relação às ações que tornassem suas atividades mais sustentáveis, contribuindo com uma melhor qualidade de vida à sociedade (CNJ, 2015).

Assim, o Conselho Nacional de Justiça- CNJ adotou políticas públicas de âmbito nacional de cunho obrigatório a todos os Tribunais do país, em prol do efetivo cumprimento das exigências voltadas para as atividades sustentáveis por parte dos gestores ligados ao Poder Judiciário. 
Considerando a necessidade de mudança de comportamento de como lidar com o meio ambiente, a busca pela melhoria da prestação jurisdicional, as exigências impostas pelo CNJ aos Tribunais, propõe-se uma abordagem de como esta problemática se dá em nível regional, pesquisando sobre a institucionalização da gestão da sustentabilidade no Poder Judiciário do Estado do Tocantins.

\subsection{Contexto e Situação Problema}

O Poder Judiciário, no papel de agente transformador de novos padrões de cultura e costumes sustentáveis junto à sociedade, inseriu a temática ambiental em sua agenda administrativa somente após a criação do Conselho Nacional de Justiça (2004), quando adotou Recomendações e Resoluções instituindo o modo racional do uso dos recursos naturais e programas voltados para a sustentabilidade, com o intuito de mobilizar servidores e magistrados de todos os Tribunais do Brasil acerca da questão socioambiental (CNJ, 2010).

Assim, por recomendação do Conselho Nacional de Justiça a responsabilidade socioambiental foi inserida na agenda do Poder Judiciário do Tocantins de forma mais incisiva, a partir de 2010, quando o Tribunal por meio do Planejamento Estratégico traçado para o período 2010-2014, desenvolveu ações de forma a organizar objetivos, metas e propostas que atendessem a demanda socioambiental (TJTO, 2015).

Ocorre que no quadriênio fixado para o desenvolvimento do Planejamento Estratégico, as ações correspondentes à responsabilidade socioambiental ocorriam por meio de ações esparsas, visto que somente com a edição da Portaria $n^{\circ} .4 .119 / 2014$, que instituiu a Comissão Gestora para implantação do Projeto Estratégico A3P no âmbito do Poder Judiciário do Estado do Tocantins, que foi dada a iniciativa para implementação de ações efusivas voltadas para a sustentabilidade nas atividades praticadas no Tribunal (TJTO, 2015)

Em 2015, o Tribunal de Justiça do Estado do Tocantins - TJTO firmou Termo de Cooperação Técnica com o CNJ, comprometendo-se em desenvolver políticas que apontassem a redução de despesas com telefonia, energia elétrica e água em todas as comarcas do Estado.

A preocupação do Tribunal com a disseminação das práticas de atividades sustentáveis se torna visível a partir da criação de um setor administrativo exclusivamente 
para tratar de questões socioambientais, denominado Núcleo de Gestão Socioambiental (Resolução 22/2015), cuja função precípua é atender as normas esculpidas na Resolução $\mathrm{n}^{\text {o. }} 201$ do CNJ, que exige dos Tribunais cumprimentos de metas voltadas para a sustentabilidade, dentre as quais, a elaboração, monitoramento e avaliação de um Plano de Logística Sustentável (TJTO, 2015).

Também em 2015, em consonância com as ordens esculpidas pelo CNJ, foi constituída uma Comissão para elaboração do Plano de Logística Sustentável do TJ/TO, instrumento de gestão socioambiental, que visa redução de gastos dos recursos naturais e a conscientização dos jurisdicionados quanto às questões socioambientais.

Assim, em 2016 foi instituído o Plano de Logística Sustentável no âmbito do Tribunal, cujo objetivo geral é o de estabelecer "mecanismos de controle e monitoramento de ações socioambientais como forma auxiliar de implementação da sustentabilidade social, ambiental e econômica na Instituição" (PLS-TJTO, 2016, p.11).

Vislumbra-se que o Tribunal de Justiça do Estado do Tocantins, tem demonstrado uma preocupação em cumprir com as determinações impostas pelo CNJ, ao firmar compromissos e delinear ações a serem implementadas no âmbito do Tribunal.

Com base no cenário apresentado, pretende-se com a presente pesquisa, analisar o processo de institucionalização da gestão socioambiental no Poder Judiciário do Estado do Tocantins. A partir dessa realidade, tem-se o seguinte problema de pesquisa: como está sendo institucionalizada a gestão sustentável no Tribunal de Justiça do Tocantins?

\subsection{Justificativa}

Com a inserção da temática na agenda dos Tribunais, tornou-se relevante investigar o processo da institucionalização das práticas sustentáveis no cotidiano das atividades jurisdicionais.

Ocorre que, com base em exame realizado junto a banco de dados de dissertações e teses, foi possível identificar que pesquisas que abordam aspectos da gestão ambiental nos Tribunais ainda são embrionárias, talvez muito se deva ao fato de que a preocupação com uma gestão sustentável nos Tribunais, só ocorreu após recomendações advindas do CNJ, a partir do ano de 2007.

A partir de então alguns trabalhos acadêmicos buscaram analisar aspetos da gestão ambiental nos Tribunais, como no caso de Brito (2012), que propôs pesquisar sobre 
indicadores da gestão ambiental na Justiça Eleitoral de Goiás. Esteves (2009) pesquisou sobre a institucionalização da gestão socioambiental no Tribunal Regional Federal da $5^{\text {a }}$ Região. Abrahão (2016) analisou a aplicação da Agenda Ambiental na Administração Pública no Superior Tribunal de Justiça. Sousa (2017) avaliou os mecanismos de gestão ambiental no Poder Judiciário Catarinense. Rek (2017) trouxe a análise do processo de institucionalização da gestão ambiental no TRE do Paraná.

Assim, foi possível verificar que em âmbito Estadual pouco se dedicou a analisar a gestão socioambiental no Poder Judiciário e quando propuseram algum estudo nesta seara, o foco não era o processo de institucionalização da gestão sustentável, como por exemplo, o trabalho de Vampré (2015), que abordou a sustentabilidade com enfoque no aprimoramento dos mecanismos de solução de conflitos ambientais pelo Poder Judiciário Estadual e de Jardim (2016), que propôs um estudo sobre a gestão ambiental no Tribunal de Justiça do Estado, mas com ênfase na educação ambiental.

Desta forma, se propõe realizar a análise do processo de institucionalização da gestão sustentável no Tribunal de Justiça do Estado do Tocantins. A proposta de pesquisa aqui sugerida se torna importante em face da contribuição teórica e social que este trabalho possa trazer à discussão que envolve a preservação dos recursos naturais, buscando identificar possíveis deficiências para ao final propor melhorias que possam contribuir com o processo.

A identificação de limitações e ou potencialidades no processo de institucionalização da gestão ambiental no Tribunal de Justiça do Estado do Tocantins, possibilita contribuir com a implementação da gestão socioambiental em uma Instituição Pública, servindo de diretriz para a compreensão do modo de inserção de práticas sustentáveis que possam servir de parâmetros para outros órgãos, unidades jurisdicionais e ou quaisquer órgãos do Poder Público, disseminando práticas positivas de sustentabilidade na Administração Pública do nosso Estado.

\subsection{Objetivos}

\subsubsection{Objetivo geral}

Esta pesquisa tem como objetivo geral analisar a institucionalização da gestão socioambiental na Administração Pública no âmbito do Tribunal de Justiça do Tocantins. 


\subsubsection{Objetivos específicos}

- Caracterizar os instrumentos de gestão socioambiental do Tribunal de Justiça do Tocantins;

- Identificar a percepção dos servidores sobre a institucionalização da gestão socioambiental no Tribunal de Justiça do Tocantins;

- Identificar potencialidades e/ou deficiências na gestão socioambiental e a partir do diagnóstico sugerir melhorias.

\subsection{Delimitação do Estudo}

O Tribunal de Justiça do Estado do Tocantins foi instalado em 6 de janeiro de 1989, de forma improvisada no fórum de Miracema, até então capital provisória do Estado do Tocantins, quando em $1^{\circ}$ de janeiro de 1990 , teve sua mudança para a Capital do Estado, Palmas.

A Corte do Tribunal é composta por 12 Desembargadores, estando sobre sua jurisdição 42 comarcas distribuídas em todo o Estado, totalizando em abril de 2018, quadro de pessoal de 2535 servidores, entre magistrados e servidores técnico-administrativos (TJTO, 2018).

O Planejamento Estratégico (2017-2020) do Tribunal, estabelece como missão a garantia da cidadania por meio da distribuição de uma justiça célere, justa e eficaz, tendo como visão institucional ser reconhecido como o mais moderno, célere e eficaz dos Tribunais do país e para tanto busca cultivar os valores da eficiência, ética, credibilidade, presteza, inovação e cooperação, responsabilidade social, transparência, comprometimento e sustentabilidade (TJTO, 2015).

Ainda de acordo com o planejamento traçado para o Tribunal de Justiça, serão implementadas políticas de gestão que visem "atenuar as desigualdades sociais e garantir os direitos de minorias, observando-se, para tanto, práticas socioambientais sustentáveis e uso de tecnologia limpa" (TJTO, 2015, p. 6)

Assim, optou-se por realizar a pesquisa e coleta de dados na própria sede do Tribunal de Justiça, conforme já dito, localizado na capital de Palmas, por ser o órgão do Poder Judiciário hierarquicamente superior no âmbito Estadual, dele provindo as 
normativas a serem implementadas e as ações a serem disseminadas nas demais comarcas do Estado.

Considerando a proposta de se estudar a institucionalização da gestão sustentável no âmbito do Tribunal de Justiça do Estado do Tocantins, pretendemos caracterizar a gestão socioambiental, por meio de apresentação de seus projetos de sustentabilidade, ações, metas e resultados.

Deste modo, a proposta é analisar os projetos implementados no âmbito do Tribunal, a partir da instituição da Agenda Ambiental na Administração Pública (A3P), notadamente o Plano de Logística Sustentável.

A Agenda Ambiental na Administração Pública foi implementada no âmbito do Tribunal a partir de 2015, com o objetivo de adoção de ações sustentáveis que despertem nos servidores a conscientização quanto à necessidade de se preservar o meio ambiente, a partir da redução do combate ao desperdício no ambiente de trabalho (TJTO, 2015).

Por sua vez, o Plano de Logística Sustentável (2016) merece destaque, visto que tem como objetivo mecanismos de controle de monitoramento de ações socioambientais (TJTO, 2016).

Analisar as ações acima discriminadas permitirá analisar a institucionalização da gestão socioambiental no Tribunal de Justiça do Estado do Tocantins, para ao final se for o caso, sugerir melhorias a partir de possíveis deficiências identificadas. 


\section{REFERENCIAL TEÓRICO}

Este capítulo objetiva estruturar o arcabouço teórico que fundamenta esta proposta de pesquisa.

Primeiramente serão abordados os fatos que levaram a construção dos conceitos e discursos sobre o desenvolvimento sustentável e gestão socioambiental por parte da Administração Pública.

A segunda seção aborda aspectos teóricos para demonstrar o papel da Administração Pública na condução de políticas públicas que objetiva o alcance do desenvolvimento sustentável. Desse modo, ressaltamos o arcabouço legal que disciplina a matéria e programas implementados para disseminar a prática de atividades preocupadas com a sustentabilidade.

Por fim, serão apresentados os mecanismos e ferramentas utilizadas pelo Poder Judiciário para a implementação da gestão sustentável em seu âmbito.

\subsection{Conceitos e Discursos sobre o Desenvolvimento Sustentável}

Por muitos anos, a humanidade viveu sem nenhuma preocupação quanto a escassez dos recursos naturais, o que acabou por causar degradação demasiadamente ao planeta, trazendo consequências negativas, perceptíveis no ar, água, alimentos e alterações climáticas, reflexo muitas vezes de uma exploração econômica desmedida que com o tempo tornou-se uma problemática para o meio ambiente e à sociedade, despertando uma preocupação mundial quanto a forma da humanidade tratar o meio ambiente em que vive.

Para Sachs (2008), a Revolução Industrial do século XVIII que buscava o crescimento econômico de forma acelerada com o uso de materiais e energias, provocando excedente de riquezas sem se preocupar com os problemas sociais e ambientais, a aceleração do crescimento populacional, catástrofes naturais, acidentes industriais e desigualdades sociais, são fatores que devem ser considerados ao se pensar em desenvolvimento, com vistas a reparar as disparidades passadas.

Diante do quadro desenhado, nos anos 60, começou-se a intensificar movimentos ecológicos, debates e reflexões por diferentes grupos e atores sociais sobre os impactos negativos que as atividades humanas ocasionavam ao planeta, com o fito de buscar 
mecanismo e soluções para mitigar as ações antrópicas que o desenvolvimento causava à sociedade (LAGO, 2006).

A publicação do livro Primavera Silenciosa ${ }^{1}$, escrito por Rachel Louise Carson em 1962, que faz referência aos pássaros mortos pela utilização de agrotóxicos, traçando interconexões entre o meio ambiente, economia e bem-estar social, causou na sociedade um despertar para consciência ambiental, em razão das bandeiras levantadas para as causas ambientalistas (NASCIMENTO, 2012).

Em 1968, um grupo de cientistas e pessoas de diversos segmentos da sociedade se reuniram para debater a respeito de assuntos relacionados, sobretudo o meio ambiente e desenvolvimento sustentável. O grupo denominado de Clube de Roma, em 1972, publicou o relatório "Limites ao Crescimento", com divulgação dos estudos realizados por eles e alertou sobre os riscos que o crescimento econômico contínuo causaria à sociedade e ao meio ambiente, se os recursos naturais continuassem sendo consumidos como havia sendo à época (MMA, 2009).

O relatório confeccionado pelo Clube de Roma serviu de alerta e de conscientização da sociedade para o fato de que a exploração dos recursos naturais no planeta tinha limites e que se não fossem observadas as consequências poderiam ser nefastas.

O referido relatório também serviu como documento de suma importância para a realização da Conferência das Nações Unidas sobre o Meio Ambiente e Desenvolvimento ocorrida em 1972, em Estocolmo na Suécia, para debates e providências sobre meio ambiente, sociedade e economia (NASCIMENTO, 2012).

A Conferência de Estocolmo reuniu líderes políticos, sociedade civil e científica de 115 países, que discutiram sobre ações que poderiam auxiliar, diminuir e eliminar os impactos provocados no meio ambiente, sendo ao final aprovada a Declaração da Conferência das Nações Unidas sobre o Meio Ambiente, com 26 princípios e um plano de ação para o meio ambiente humano com 109 recomendações (LAGO, 2006).

Para Lago (2006), as maiores conquistas da Conferência de Estocolmo, teria sido a inserção do tema ambiental de forma definitiva na agenda multilateral, as definições das prioridades das futuras negociações, criação do Programa das Nações Unidas para o Meio Ambiente (PNUMA), estímulo à criação de órgãos e fortalecimento das organizações não-

\footnotetext{
${ }^{1}$ O livro foi considerado um dos livros mais influentes no mundo em razão da causa ambientalista levantada após a sua publicação.
} 
governamentais dedicados às questões do meio ambiente, e o envolvimento da sociedade civil quanto as questões ambientais.

A partir daí, a preocupação com a conservação dos recursos naturais passou a ser encarada como questão de grande inquietação, que merecia maior atenção em busca de soluções que viessem corrigir as ações humanas com o meio ambiente, desencadeando uma série de conferências e reuniões a nível internacional para a discussão sobre o assunto.

Após a reunião de Estocolmo, o conceito de desenvolvimento foi apresentado por Ignacy Sachs (1974), como ecodesenvolvimento, visto como o crescimento econômico preservando-se a ecologia.

Em 1987, a Assembleia Geral das Nações Unidas, instituiu o "Relatório da Comissão Mundial sobre o Meio Ambiente e Desenvolvimento", conhecido como Relatório Brundtland, com o título de "Nosso Futuro Comum", que traçava um paralelo e discussões sobre questões ambientais e desenvolvimento, conforme trecho do discurso contido no Relatório:

\footnotetext{
Muito de nós vivemos além dos recursos ecológicos, por exemplo, em nossos padrões de consumo de energia. No mínimo, o desenvolvimento sustentável não deve pôr em risco os sistemas naturais que sustentam a vida na Terra: a atmosfera, as águas, os solos e os seres vivos. Na sua essência, o desenvolvimento sustentável é um processo de mudança na qual a exploração dos recursos, o direcionamento dos investimentos, a orientação do desenvolvimento tecnológico e a mudança institucional estão em harmonia e reforçam o atual e futuro potencial para satisfazer as aspirações e necessidades humanas (RELATÓRIO BRUNDTLAND, 1987, p. 49).
}

O Relatório de Brundtland chamou a atenção para o fato de que as nações devem buscar alternativas para o desenvolvimento; que o desenvolvimento que não melhora a qualidade de vida da sociedade não pode ser considerado desenvolvimento; e que o desenvolvimento é possível sem destruir os recursos naturais, conciliando crescimento econômico com conservação ambiental (ONU, 1987).

O Relatório apresenta o termo Desenvolvimento Sustentável, o que foi adotado internacionalmente "como sendo aquele que atende às necessidades do presente sem comprometer a possibilidade de atender às necessidades das gerações futuras" (NASCIMENTO, 2012, p. 36).

Para Guimarães (2001), o Desenvolvimento Sustentável deve ser ambientalmente sustentável por meio do acesso e uso dos recursos naturais e preservação da biodiversidade; socialmente sustentável, com a redução da pobreza, das desigualdades 
sociais e promoção da justiça e da equidade; culturalmente sustentável com a conservação dos sistemas de valores, práticas e símbolos de identidade; e politicamente sustentável com o aprofundar na democracia e garantir o acesso e a participação de todos nas decisões de ordem pública. Rabelo (2008) compartilha do mesmo posicionamento afirmando que o Desenvolvimento Sustentável precisa ser economicamente sadio, socialmente justo, ambientalmente responsável e politicamente fundamentado na participação da sociedade.

Já Nascimento (2012), exemplifica o tripé da sustentabilidade, pautado na aliança entre econômico, social e ambiental, conforme caracterizado na figura1:

Figura 1 - Fundamentos da Sustentabilidade

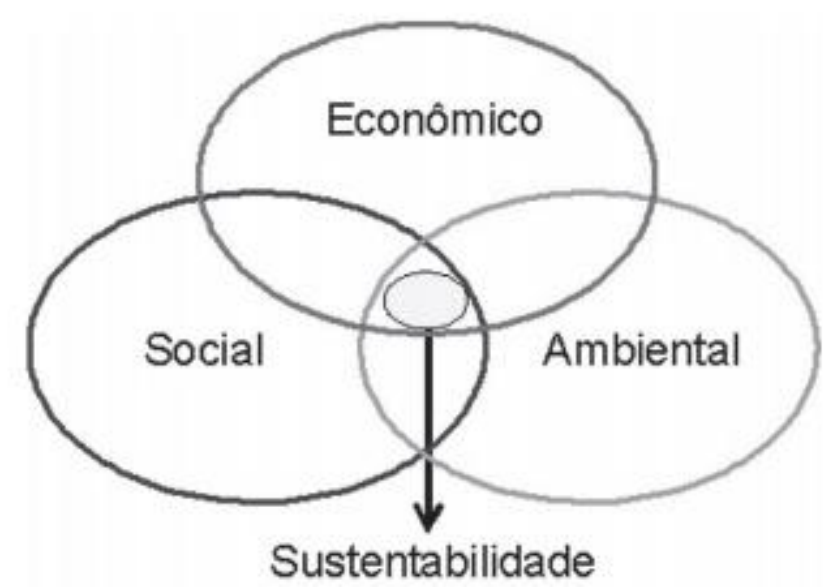

Fonte: Nascimento (2012, p. 38)

O termo Desenvolvimento Sustentável foi fortalecido com a realização da segunda Conferência das Nações Unidas pelo Meio Ambiente e Desenvolvimento, conhecida como Cúpula da Terra ou Rio-92, ocorrida no Brasil na cidade do Rio de Janeiro (SILVA, 2012) e ficou conhecida com a maior conferência realizada sobre o assunto, com a participação de 172 países e a presença de 108 Chefes de Estado ou Governo (MMA, 2009).

A Conferência Rio-92 tinha como objetivo a elaboração de estratégias e medidas que auxiliassem na reversão da degradação ambiental em nível mundial, tendo como escopo a elaboração de estratégias e medidas que revertessem a degradação ambiental no contexto dos esforços nacionais e internacionais para a produção do desenvolvimento sustentável e ambientalmente adequado para todos os países (LAGO, 2006). 
A Conferência deixou como legado importantes documentos: a Carta da Terra, a Agenda 21, as Convenções do Clima e da Biodiversidade, a Declaração de Princípios para as Florestas e a Declaração do Rio para o Meio Ambiente e Desenvolvimento (DORAN, 2002).

Dentre os documentos acima, a Agenda 21 serve como referência e parâmetro para os governos na elaboração de projetos voltados para minimizar e ou reverter ações de cunho socioambiental, buscando mecanismos para as nações reduzirem e ou eliminarem padrões insustentáveis de produção e consumo. Segundo aponta o documento confeccionado na Conferência das Nações Unidas sobre Meio Ambiente (1995):

\begin{abstract}
A Agenda 21 está voltada para os problemas prementes de hoje e tem o objetivo, ainda, de preparar o mundo para os desafios do próximo século. Reflete um consenso mundial e um compromisso político no nível mais alto no que diz respeito a desenvolvimento e cooperação ambiental. O êxito de sua execução é responsabilidade, antes de mais nada, dos Governos. Para concretizá-la são cruciais as estratégias, os planos, as políticas e os processos nacionais. A cooperação internacional deverá apoiar e complementar tais esforços nacionais. (CONFERÊNCIA DAS NAÇÕES UNIDAS SOBRE MEIO AMBIENTE, 1995, item 1.3).
\end{abstract}

Dez anos após a realização da Conferência do Rio de Janeiro, as Nações Unidas pelo Desenvolvimento Sustentável realizou a Cúpula Mundial sobre Desenvolvimento Sustentável, conhecida como Conferência Rio+10, em Joanesburgo na África do Sul, com representantes de 189 países e participação de Organizações não Governamentais (ONG’S) e representantes das sociedades civis.

O objetivo da reunião da cúpula era discutir a preservação do meio ambiente, saneamento básico, saúde, fornecimento de água, entre outros fatores, além de realizar uma avaliação quanto aos resultados alcançados após a Eco-92, principalmente no que refere ao cumprimento das regras estabelecidas na Agenda 21 (CERQUEIRA, 2004).

Salienta-se que a cúpula não se restringiu a questões ambientais, discutiu-se questões com aspectos sociais e qualidade de vida das pessoas, relacionadas à diminuição do número de pessoas que vivem abaixo da linha de pobreza, surgindo-se a expressão sustentabilidade para as discussões em voga (CERQUEIRA, 2004).

A Cúpula do Desenvolvimento Sustentável deixou como legado a "Declaração de Joanesburgo", documento onde as nações reafirmaram o compromisso com as metas da Agenda 21 e no alcance do desenvolvimento sustentável, contudo, não estabeleceu metas 
ou prazos para o seu cumprimento, o que para muitos torna vago os seus resultados, dificultando cobranças dos países que firmaram a declaração (MAGALHÃES, 2017).

A Conferência das Nações Unidas pelo Desenvolvimento Sustentável viera ocorrer novamente no Brasil na cidade do Rio de Janeiro em 2012, o que ficou conhecida como Rio+20. O objetivo da reunião era tão somente renovar os compromissos dos governantes com o desenvolvimento sustentável firmados nas cúpulas anteriores, cujos principais temas abordados foram desenvolvimento sustentável, economia verde, inclusão social e pobreza (GUIMARÃES; FONTOURA, 2012).

A participação dos Chefes de Estado e de Governo no evento não era obrigatória, pois o mesmo não possuía o cunho de tomada de decisões por parte dos Estados, fato que culminou na ausência de importantes líderes mundiais, mas ainda assim, teve representantes de 189 países.

Ao final da conferência foi aprovada uma declaração política denominada de " $\mathrm{O}$ Futuro que Queremos”, com o compromisso de cooperação entre os países para construção de uma sociedade justa e sustentável, mas segundo Guimarães e Fontoura (2012), o conteúdo da declaração é insuficiente e não representativos, visto que os governos participantes saíram sem assumir deveres que deveriam ser cumpridos e sem metas para serem avaliadas.

Com as discussões nos eventos sobre meio ambiente, foi se desenhando a percepção sobre o conceito desenvolvimento, inicialmente difundido como ecodesenvolvimento (1974), desenvolvimento sustentável (1987) e sustentabilidade (2002), cuja proposta é uma só, promover reflexões sobre o desenvolvimento preservandose o meio ambiente (SACHS, 2008).

Contudo, a maioria dos autores que se dedicam ao assunto tem adotado o conceito difundido pelo relatório de Brundtland, cuja percepção é o de aliar o desenvolvimento sem ignorar o meio ambiente, preservando-se o sustento das próximas gerações.

\subsubsection{A gestão socioambiental: principais aspectos conceituais}

O grande desafio ao se falar em conservação do meio ambiente é alinhar o crescimento econômico sob a perspectiva do desenvolvimento humano e da conservação ambiental. E este desafio, não se resume em atividades exclusivamente produtivas, mas também nas atividades do cotidiano. 
A globalização, o desmatamento, as mudanças climáticas, poluição, desigualdade social, consumo e produção de resíduos, entre outros, segundo Seiffert (2014), são aspectos problemáticos que demandam de iniciativas imediatas, fazendo-se desenvolver ações que insertam os padrões de consumo, educação, gerenciamento de recursos e fontes de energias.

É cediço que as ações voltadas para o fim da conservação ambiental, envolvem diversos atores, poder público, empresas e sociedade, cujos interesses muitas vezes não convergem entre si, sendo necessário para a solução do conflito que se adotem medidas com o fim de se solucionar o impasse, deixando-se as vaidades individuais para se pensar no coletivo.

Desta forma, a gestão ambiental é o melhor mecanismo em prol da celeuma estabelecida, visto que, nada mais é, que um processo de mediação de conflitos de interesses em prol do meio ambiente (LAYRAGUES, 2004).

A essência da gestão ambiental seria, portanto, ações desenvolvidas de modo coordenadas, com o intuito de se combater os conflitos existentes, de forma a coibir ou minimizar a degradação que as atividades humanas causem ao ambiente natural, (COELHO, 2016).

Referidas ações tornam-se fundamentais, visto que, a gestão ambiental não se limita a iniciativa privada e, no seu campo de atuação, poder público e sociedade civil não se oporiam, mas se complementariam (BERTÉ, 2009). Assim, é essencial buscar mecanismo em prol do envolvimento do maior número de pessoas voltadas para solução da problemática, possibilitando atingir a qualidade ambiental desejada.

Segundo Dias (2006) a gestão ambiental, é a mais importante das ferramentas dirigidas ao desenvolvimento sustentável, cujo objetivo é promover a interação entre os elementos social, econômico, ambiental e político, aliado ao fato do dever de observância dos atos normativos emanados do poder público a respeito.

A gestão ambiental possui um campo de atuação vasto, cuja magnitude, se justifica quando a temática ambiental é compreendida como um todo, visto a sua complexidade (PHILIPPI JR, 2009).

Tinoco e Kraemer (2004, p.109), caracterizam a gestão ambiental como:

[...] o sistema que inclui a estrutura organizacional, atividades de planejamento, responsabilidades, práticas, procedimentos, processos e recursos para desenvolver, implementar, atingir, analisar criticamente e manter a política 
ambiental. É o que se faz para minimizar ou eliminar os efeitos negativos provocados no ambiente por suas atividades.

Para Meyer (2000, p. 38), ao se falar em gestão ambiental é importante observar 4 fragmentos: o objeto, os meios, os instrumentos e a base de atuação, visto que:

\begin{abstract}
O objeto, consiste em manter o meio ambiente saudável, para atender as necessidades humanas atuais, sem comprometer o atendimento das necessidades no futuro; Os meios, implicam na atuação sobre as modificações causadas ao meio ambiente em virtude do uso exagerado e/ou descarte indevido decorrente das atividades humanas, a partir de um plano de ação variável técnica e economicamente, com prioridades definidas; Os instrumentos, são os monitoramentos, controles, taxações, imposições, subsídios, divulgação, treinamento e conscientização, além de obras e ações mitigadoras; a base de atuação, é representada pelos diagnósticos e prognósticos (cenários) ambientais a partir de estudos e pesquisas dirigidas à busca de soluções para os problemas detectados.
\end{abstract}

Segundo Phillip Jr (2009), a gestão ambiental, portanto, é a implementação de políticas públicas ambientais e a conscientização ambiental para se atingir o objetivo de diminuição do impacto para um desenvolvimento sustentável, comprometendo-se com a manutenção e melhoria do meio ambiente.

Nicolaides (2006), destaca que durante o percurso de implementação da gestão ambiental, esta deve ser observada e tratada com esmero, pois os obstáculos que surgem ao longo do caminho causa entraves em sua implementação, sempre haverá resistência por parte dos funcionários que estão acostumados com a sistematização do trabalho e não querem mudanças, a própria inércia da instituição acomodada com a situação e não olham com bom grado propostas trazidas, falta de conscientização, resistências para mudar a mentalidade dos envolvidos, além da falta de conhecimento.

\title{
2.2 Políticas Ambientais no Brasil
}

Este subitem visa delinear o papel preponderante do Estado quanto à preservação do meio ambiente, visto que lhe compete fomentar mecanismos por meio de instituição de políticas públicas.

Deste modo, apresentamos aspectos conceituais sobre políticas públicas e teceremos sobre como o assunto foi tratado por nossos legisladores, descrevendo as políticas nacional do meio ambiente, da educação ambiental, da mudança do clima e dos resíduos sólidos, preponderantes para compreensão das ações desenvolvidas pela Administração Pública com o objetivo da disseminação de práticas sustentáveis. 


\subsubsection{Aspectos conceituais sobre políticas públicas}

As tomadas de decisões sobre políticas públicas são complexas e torna-se essencial a compreensão dos fatores que influenciam a dinâmica do processo em que são produzidas.

As políticas, no estado de direito democrático, tendem a expressar a forma desejada pela sociedade em solucionar os problemas que surgem. Nestas condições, podese dizer que toda política parte de um movimento da sociedade em torno de um problema ou conflito (FLORIANO, 2007).

Dye (1972), conceituava a política pública como sendo tudo aquilo que os governos escolhem fazer ou não fazer, já para Secchi (2015) para se formular uma política pública é necessário a elaboração de uma diretriz para o enfrentamento de um problema público, que envolve a intenção pública de se dar uma resposta a um problema enfrentado pela sociedade.

Em uma política há sempre uma teia de decisões e ações que implementam valores, uma instância que, uma vez constituída, vai conformando o contexto no qual as decisões futuras serão tomadas e mais do que uma única decisão, exige envolvimento de uma teia de decisões e o desenvolvimento de ações no tempo (DAGNINO, 2002).

Descreve Heidemann (2009) que a política pública envolve a intenção e a ação do governo. Já Souza (2006), define política pública como sendo nada mais que colocar o governo em ação e se for necessário analisar a ação desenvolvida e ao longo da sua consecução propondo as devidas mudanças até atingir o seu objetivo.

Sousa (2002), afirma que para compreensão da tomada de decisão sobre a adoção de uma política pública, é importante que se tenha em mente um processo compreendido em três fases imprescindíveis: formulação, implementação e avaliação. Sendo que a formulação é a decisão do que será alvo de política pública ou não, a escolha dentre várias opções qual a política pública será sugerida. Já a implementação, é a execução propriamente dita da política pública. E a avaliação é onde se busca as respostas se a política formulada foi de fato executada e qual o grau de aceitação da política por parte dos beneficiados.

Neste sentido, de acordo com Rua (2012), a compreensão das fases de inserção da política pública, é essencial para permitir ao analista melhor compreender o problema para 
o qual a política pública foi desenhada, seus possíveis conflitos, a trajetória seguida e o papel dos indivíduos, grupos e instituições que estão envolvidos na decisão e que serão afetados pela política pública escolhida.

Pode-se, portanto, entender por políticas públicas na seara ambiental como a tomada de decisão do Estado diante das demandas da sociedade, que se traduz, entre outras coisas, em legislação, programas e projetos de ações voltados ao uso dos recursos naturais e preservação do ambiente natural.

O Brasil, seguindo a tendência mundial desenvolveu políticas ambientais, fomentadas em seu grosso modo por força normativa, que inseridas no ordenamento jurídico passa a ser regulamento que tem que ser observado por todos indistintamente, visando à conscientização a respeito do meio ambiente.

Segundo Floriano (2007, p. 33):

\begin{abstract}
As políticas de gestão ambiental tendem a se concentrar sobre determinados elementos naturais aos quais se dá maior atenção por sua importância para a civilização, como por exemplo: a biodiversidade e unidades de conservação, os recursos hídricos, os solos, as paisagens excepcionais, os sítios fósseis, atividades antrópicas, processos e produtos da civilização e seus rejeitos, por influência tanto na qualidade de vida do ser humano, quanto sobre o ambiente natural.
\end{abstract}

Ainda, para Floriano (2007), a formulação de políticas públicas ambientais, dependem de uma conscientização social ou uma preocupação social, que gerem movimentos que induzem a tomada de ações e programas que servem como medidoras para solução dos conflitos estabelecidos nas questões que tratam do meio ambiente.

Paul Little (2003, p.18), defende que as políticas públicas ambientais "são aquelas que procuram garantir a existência de um meio ambiente de boa qualidade para todos os cidadãos do país”.

Diante deste contexto, abordaremos algumas políticas públicas ambientais adotadas pelo Brasil, como a Política Nacional do Meio Ambiente, Política de Educação Ambiental, Política Nacional de Mudança de Clima e Política Nacional de Resíduos Sólidos, como forma de demonstrar como a temática vem sendo tratada em nosso país, pois esse arcabouço molda o comportamento nas instâncias pública e privada, configurando-se como antecedentes das ações ambientais desenvolvidas atualmente pelos órgãos públicos. 
2.2.2 A política nacional do meio ambiente

Moura (2016), afirma que a preocupação com questões ambientais no Brasil de forma sintetizada, começou pelos setores florestal e hídrico, fato que ocorreu por volta da década de 1930, com a intensificação da industrialização, quando foram editadas leis de proteção aos recursos naturais, como Código de Águas e Código Florestal (1934), Código de Mineração (1937) e criação de parques nacionais e de proteção do patrimônio histórico e artístico nacional.

Muito embora houvessem a edição das referidas leis voltadas para a preservação do meio ambiente, a política ambiental ainda não havia de fato sido incrementada no Brasil, o que viera ocorrer somente em 1970, paralelos aos debates de Conferência da ONU, mas precisamente com a criação da Secretaria Especial de Meio Ambiente (SEMA) (MELO e BEZERRA, 2009)

Mas, somente em 1981 com o advento da Lei 6.938 que no Brasil foi instituída a Política Nacional do Meio Ambiente, marco da política ambiental brasileira, vez que estabelece os objetivos, as ações e os instrumentos da política ambiental. Norma de gestão ambiental de cunho nacional, promulgada para traçar diretrizes, fins, mecanismos, formulação e aplicação da política pública ambiental em nosso país (BRASIL, 1981).

A institucionalização da Política Nacional do Meio Ambiente visava a preservação, melhoria e recuperação da qualidade ambiental propícia à vida, propendendo assegurar, no país, condições ao desenvolvimento sócio-econômico, aos interesses da segurança nacional e da dignidade da vida humana (BRASIL, 1981).

A Política Nacional do Meio Ambiente trouxe como princípios basilares orientar as ações governamentais em prol da conservação do meio ambiente, o patrimônio público de uso coletivo do povo; racionalizar e fiscalizar o uso dos recursos naturais; proteger os ecossistemas; controlar as atividades potencialmente e efetivamente poluidoras; incentivar o estudo e a pesquisa de tecnologias que visem a proteção dos recursos ambientais; acompanhar o estado da qualidade ambiental; recuperar as áreas degradadas e proteger as ameaçadas de degradação; além de promover a educação em todos os níveis de ensino (BRASIL, 1981).

De acordo com os princípios delineados, a formulação das diretrizes da Política Nacional do Meio Ambiente seria estabelecida por meio de normas e planos, com o fim precípuo de orientar a ação dos governos, por ações conjuntas ou individualizadas pelo 
entes Federal, Estadual ou Municipal, para a preservação da qualidade ambiental e manutenção do equilíbrio ecológico.

Monosowski (1989) afirma que uma das grandes inovações trazida pela lei foi a previsão da utilização de instrumentos de gestão ambiental (Art. $9^{\circ}$ da PNMA) de alcance nacional, constituindo-se uma nova etapa no modo de utilização e apropriação dos recursos naturais para a atividade produtiva.

Segundo Nascimento (2012), apesar dos avanços alcançados com as diretrizes traçadas pela Política Nacional do Meio Ambiente a sua efetivação foi construída passo a passo, sendo implementada ao longo dos anos seguintes, principalmente na década de 1990, com adoção de medidas que visavam o cumprimento das obrigações estabelecidas na lei.

Destaca-se a criação de institutos, conselhos, órgãos como o Sistema Nacional de Meio Ambiente (SISNAMA), Conselho Nacional do Meio Ambiente (CONAMA), Instituto Brasileiro do Meio Ambiente e dos Recursos Naturais Renováveis (IBAMA),

Ao SISNAMA, foi atribuída a função de realizar a junção e articular o conjunto de instituições cujas atividades se relacionam com proteção e melhoria da qualidade ambiental nas três esferas de governo. Ao CONAMA coube propiciar uma gestão participativa, com o envolvimento dos cidadãos na tomadas de decisões relacionadas à temática ambiental. E ao IBAMA, fiscalizar e punir os infratores do meio ambiente.

A Lei da Política Nacional do Meio Ambiente teve sua base chancelada pela Carta Magna de 1988, onde se encontra um capítulo inteiro dedicado às normas de proteção ao meio ambiente. Muito embora a Constituição Federal tem trazido praticamente a mesma abordagem encontrada na Política Nacional do Meio Ambiente, esta trouxe uma inovação, ao destacar a preocupação com as gerações futuras, conduzindo instrumentos com o altruísmo de conciliar o desenvolvimento econômico e a disponibilidade de recursos naturais, garantidas a longo prazo conforme podemos observar na determinação esculpida em seu art. $225^{2}$ (BRASIL, 1988).

\footnotetext{
${ }^{2}$ Art. 225. Todos têm direito ao meio ambiente ecologicamente equilibrado, bem de uso comum do povo e essencial à sadia qualidade de vida, impondo-se ao poder público e à coletividade o dever de defendê-lo e preservá-lo para as presentese futuras gerações.
} 


\subsubsection{A política de educação ambiental}

Uma Política Nacional de Meio Ambiente bem definida e traçada não é garantia de uma implementação bem sucedida, para a sua eficiência é necessário o envolvimento de todos, seja governo, empresas e ou sociedade como agentes fiscalizadores na defesa do meio ambiente. Mas para que ocorra a participação de todos no processo, é fundamental um nível de conhecimento e conscientização sobre o assunto, obtidos por meio da educação.

A Educação Ambiental é instrumento basilar para capacitação da população sobre os problemas ambientais, é por meio da educação que se busca mecanismo que propiciem a tomada de consciência sobre a gravidade dos problemas ambientais (MARCATTO, 2002).

A busca pela disseminação da Educação Ambiental não é recente, pois desde 1977, em Tbilisi, ex-União Soviética, onde ocorreu a primeira Conferência Governamental de Educação Ambiental, que se discutiam a necessidade de implantação da educação ambiental para a população, definindo-se objetivos e estratégias para a sua inclusão e adoção por governos, administradores, políticos e educadores (CZAPSKI, 1998).

O tema Educação Ambiental se mostra tão importante que a Agenda 21, documento operacional da ECO 92, definiu a Educação Ambiental como área prioritária, dedicando um capítulo próprio com orientações de como a mesma deve ser organizada (ONU, 1992)

Seguindo orientações da Própria Política Nacional do Meio Ambiente e disposições esculpida na Constituição Federal que ordena "promover a educação ambiental em todos os níveis de ensino e a conscientização pública para a preservação do meio ambiente" (BRASIL, 1988, art. 222), foi instituído no Brasil a Política Nacional da Educação Ambiental com a promulgação da Lei $n^{\circ}$. 9.795, sancionada em 27 de abril de 1999, estabelecendo os princípios relativos à Educação Ambiental que deverão ser observadas em todo o país.

Na referida lei, educação ambiental é compreendida como processo por meio dos quais os indivíduos e a coletividade constroem valores socais, conhecimento, habilidades, atitudes e competências voltadas para a conservação do meio ambiente (BRASIL, 1999).

A partir da política adotada, a Educação Ambiental tornou-se um componente essencial e permanente da educação nacional, devendo obrigatoriamente estar presente, em 
todos os níveis e modalidade do processo educativo, em caráter formal e não-formal (BRASIL, 1999)

A sensibilização por meio da educação propicia uma participação consciente nas discussões e decisões a serem tomadas, promovendo a possibilidade de manifestação com conhecimento do que é abordado, realizando-se uma avaliação crítica sobre o assunto.

Assim, os princípios básicos da educação ambiental são constituídos de: enfoque holístico, democrático e participativo; a concepção do meio ambiente em sua totalidade, considerando a interdependência entre o meio natural, sócio-econômico e o cultural, sob o enfoque da sustentabilidade; o pluralismo de ideias e concepções pedagógicas; a permanente avaliação crítica do processo educativo; a abordagem articulada das questões ambientais locais, regionais, nacionais e globais; a vinculação entre a ética, educação, trabalho e as práticas sociais; o reconhecimento e o respeito à pluralidade e à diversidade individual e cultural (BRASIL, 1999).

São objetivos fundamentais da educação ambiental definidos na referida lei (entre outros): democratização das informações; fortalecimento da consciência crítica sobre a problemática social e ambiental; incentivo à participação individual e coletiva, de forma permanente e responsável na preservação do meio ambiente; o fortalecimento da cidadania, autodeterminação dos povos e solidariedade; o desenvolvimento de uma compreensão integrada do meio ambiente em suas múltiplas e complexas relações (BRASIL, 1999).

A promoção da educação ambiental é dever de todos os entes federativos e quando abordado na educação escolar este deve ser apresentada de forma transversal, ou seja, deve ser abordada e associada em todas as disciplinas multidisciplinarmente. E quando a promoção da educação ambiental se der pela educação não-formal as ações devem ser voltadas à sensibilização da coletividade para a organização e participação na defesa da qualidade do meio ambiente (BRASIL, 1999).

A implementação da educação ambiental como política pública, propicia o fortalecimento da cidadania ambiental, com influência direta na democratização da gestão ambiental pública, pretendendo-se o maior envolvimento possível da sociedade e uma difusão e divulgação do tema de forma mais ampla possível (MEC, 2007). 
2.2.4 A política nacional sobre a mudança do clima

Klein (2016), afirma que para se evitar um futuro com sérios problemas climáticos é necessário que a população desenvolva um poder revolucionário e procure mudar a maneira como se encara o modo de viver, principalmente em assuntos ligados à economia e modo de produção, segundo a autora a crise climática pode constituir a base de um poderoso movimento de massas que necessitem de ação coletiva sem precedentes, que demanda o abandono da ideologia capitalista arraigada no seio social.

Chefes de Estado, sociedade civil e cientistas, durante a realização da Conferência das Nações Unidas para o Meio Ambiente e o Desenvolvimento, Rio 92, com a presença de 179 países se uniram para consolidar uma agenda global para minimizar os problemas ambientais que causam consequências diretas às mudanças climáticas, elaborando-se a Convenção-Quadro das Nações Unidas sobre Mudança do Clima (UNFCCC), cujo fim precípuo é reunir países em um esforço conjunto para estabilizar as concentrações de gases do efeito estufa em níveis que não resultem em uma mudança de clima catastróficas.

A Convenção conta com 193 signatários, dentre eles o Brasil, que se comprometeram compartilhar de responsabilidades comuns, mas diferenciadas, na tentativa de redução de emissões de gases do efeito estufa, seguindo a linha de que aqueles países que mais contribuíram para emissão de gases devem esforçar-se mais na redução pretendida e de que os países desenvolvidos devem assumir um papel de liderança no combate às mudanças climáticas, inclusive com a prestação de apoio financeiro e tecnológico aos países menos desenvolvidos (MMA, 2009).

O Brasil para concretizar o seu compromisso, na redução de emissão de gases, desenvolveu a Política Nacional sobre Mudança do Clima (PNMC), materializada pela Lei 12.187 de 29 de dezembro de 2009, ferramenta pelo qual estabeleceu um conjunto de princípios, objetivos, diretrizes e instrumentos que orientem as ações estatais para concretização da política pública fomentada.

Instituiu a lei que as ações para promoção da redução sobre a mudança do clima é de responsabilidade dos entes políticos e dos órgãos da Administração Pública, que devem observar os princípios da precaução, da prevenção, da participação cidadã, do desenvolvimento sustentável e o das responsabilidades comuns instituído em âmbito 
internacional, devendo suas ações de governos serem compatibilizadas com os objetivos, diretrizes e metas instituídas pela PNMC (BRASIL, 2009).

Os objetivos da Política Nacional sobre Mudança do Clima deve estar em consonância com o desenvolvimento sustentável a fim de buscar o crescimento econômico, a erradicação da pobreza e a redução das desiguais sociais (BRASIL, 2009).

Visando atender os referidos objetivos a lei prevê que as instituições financeiras oficiais disponibilizarão linha de crédito e financiamento específicos, como meio de estimular agentes privados a seguir as diretrizes da PNMC, em suas ações e responsabilidades sociais (BRASIL, 2009).

Voluntariamente o Brasil se comprometeu por meio de suas ações, reduzir entre $36,1 \%$ e 38,9\% até 2020 as emissões de gases de efeito estufa, cooperando dentro de sua contribuição na emissão de gases na atmosfera. Para auxiliar no alcance das metas de redução, foi estabelecido a necessidade de se criar planos setoriais de mitigação e adaptação nos âmbitos local, regional e nacional (BRASIL, 2009).

Segundo Berté (2012), as emissões de antrópicas podem ser quantificadas e verificadas, por isso é possível firmar os planos com metas gradativas, considerando setores que deverão ser analisados diversificadamente, como no caso de: geração e distribuição de energia elétrica, transporte público urbano, indústria, serviços de saúde e agropecuária, considerando as suas especificidades.

A Tabela 1 demonstra os resultados obtidos com a redução de emissão de gases no período de 2005 a 2012:

Tabela 1- Redução Emissão de Gases no Período de 2005 a 2012

\begin{tabular}{|c|c|c|c|}
\hline & \multicolumn{2}{|c|}{ Emissỏes em $\mathrm{GgCO}_{2}$ eq } & \multirow{2}{*}{$\begin{array}{l}\text { Variaçóes } \\
\text { 2005-2012 }\end{array}$} \\
\hline & 2005 & 2012 & \\
\hline Energia & 328.377 & 446.154 & $35,9 \%$ \\
\hline Processos industriais & 77.943 & 85.365 & $9,5 \%$ \\
\hline Agropecuairia & 415.724 & 446.445 & $7,4 \%$ \\
\hline Florestas & 1.179 .067 & 175.685 & $-85,1 \%$ \\
\hline Residuos & 41.887 & 49.755 & $18,8 \%$ \\
\hline TOTAL & 2.042 .998 & 1.203 .424 & $-41,1 \%$ \\
\hline
\end{tabular}

Fonte: Ministério do Meio Ambiente (2013) 
É possível identificar pela análise da tabela, conforme já afirmado, que houve diminuição na emissão de gases $\mathrm{GgCO}^{2}$ eq no período de 2005 a 2012, cuja soma total dos setores analisados: energia, processos industriais, agropecuária, florestas e resíduos, em 2005 geravam um total de 2.042.998, em 2012, após implantação da PNMC, registrava o total de 1.203.424.

Destaca-se que a Política Nacional sobre a Mudança do Clima, foi expressa ao estatuir o dever da Administração Pública, quanto à necessidade de se observar em todas as atividades de governo a política instituída, contribuindo com a redução dos gases de efeito estufa, obrigando a Administração Pública adotar medidas e meios de gestão ambiental que contribuem para a proteção do sistema climático global.

\subsubsection{A política nacional de resíduos sólidos}

Segundo a Assembleia Geral das Nações Unidas (2011), "a causa principal da contínua deterioração do meio ambiente são as modalidades insustentáveis de produção e consumo".

O consumo gera lixo e este crescimento desenfreado de resíduos sólidos pela população é um dos mais importantes temas a ser abordado ao se falar em qualidade de vida do meio ambiente, exigindo-se uma mudança de comportamento dos atores sociais com o manejo ambientalmente saudável dos resíduos sólidos (ONU, 2011).

Visando corroborar com as diretrizes apresentadas pela ONU e seguindo com as demais estratégias da Política Nacional do Meio Ambiente, foi instituída em 02 de agosto de 2010, a Política Nacional de Resíduos Sólidos (PNRS), com o advento Lei 12.305, após 20 anos de tramitação junto ao Congresso Nacional.

A Política Nacional de Resíduos Sólidos, assim como as demais políticas públicas apresentadas, reúne um conjunto de princípios, objetivos, instrumentos, diretrizes, metas e ações que devem ser implementadas por cada ente da Federação de forma individualizada ou por ações conjuntas dos Governos Federal, Estadual e Municipal, devendo estas serem observadas pelo poder público e privado (BRASIL, 2010)

A lei trouxe instrumentos fundamentais para a gestão ambientalmente racional dos resíduos, que permitem a prevenção e a redução na sua geração, buscando inserir a prática de hábitos de consumo sustentável que propiciem o aumento da reciclagem, da reutilização dos resíduos e da destinação adequada dos rejeitos (BRASIL, 2010) 
Juras e Araújo (2012), afirmam que a lei trouxe inúmeros avanços, entre eles a responsabilidade compartilhada pela destinação adequada do lixo entre o poder público, empresas e consumidores, corroborando a ideia ao afirmar que:

[...] com a crescente geração e a mudança no teor dos resíduos domiciliares, com proporção cada vez maior de resíduos não biodegradáveis, não era socialmente justo fazer cair sobre toda a sociedade, por meio da responsabilização única do poder público, o ônus da correta gestão do lixo urbano (JURAS; ARAÚJO, 2012, p. 75)

A lei congrega conceitos importantes e inovadoras ferramentas para a gestão de resíduos sólidos como: acordo setorial, responsabilidade compartilhada, logística reserva, coleta seletiva, sistema de informações sobre a gestão dos resíduos sólidos, catadores de materiais recicláveis, planos de resíduos sólidos dentre outras (BRASIL, 2010).

A Instituição da responsabilidade compartilhada dos geradores dos resíduos, por exemplo, demonstra a necessidade do comprometimento em cadeia da coletividade, pois envolve fabricantes, importadores, distribuidores, comerciantes e o cidadão. A logística reversa, um dos mecanismos dessa responsabilidade conjunta, modelo que permitem à população a forma adequada de devolução dos resíduos pós-consumo, permitindo que não se realize o descarte de forma aleatória e inadequada, como ocorre na aquisição de produtos relacionados com agrotóxicos, pilhas, baterias, pneus, óleos lubrificantes, lâmpadas fluorescentes, produtos eletrônicos, dentre outros (MMA, 2010)

A lei também traça metas que contribuirão para a eliminação dos lixões, cujo planejamento envolve planos a ser tratado em cunho nacional, estadual, municipal, microrregional, intermunicipal e metropolitano, podendo os entes federados reunirem-se por meio de consórcios ou parceria público privada, para elaboração de seus planos de gerenciamento de resíduos sólidos.

A lei inova ao realizar a inclusão de catadores de materiais recicláveis e reutilizáveis, que podem auxiliar na logística reversa e na coleta seletiva, incentivando à criação e o desenvolvimento de cooperativas ou de outras formas de associação com este fim (MMA, 2010).

Já afirmou-se no item 2.2.1, que um dos pontos forte das Políticas Nacional do Meio Ambiente, é a integração da legislação, o que torna-se visível ao se falar da PNRS, face a necessidade de articulação de sua ações com a Política Nacional de Educação Ambiental, divulgando para população por exemplo as maneiras dos rejeitos dos bens 
consumidos na mesma proporção da divulgação para seu consumo e a influência que esta pode causar na Política Nacional sobre Mudança do Clima, visto que um de seus objetivos era alcançar o índice de reciclagem de resíduos em 20\% até 2015.

\subsection{Instrumentos de Gestão Socioambiental na Administração Pública}

Além dos aspectos normativos impostos no ordenamento jurídico, compete ainda ao Estado promoção de programas, projetos e ações que busquem a prática de ações que visem disseminar atividades voltadas para a sustentabilidade.

Assim, descreveremos neste item a respeito dos programas desenvolvidos pela Administração Pública que busquem incentivar a produção e o consumo sustentável de bens e serviços, estimulando a mudança de comportamento dos agentes públicos para incorporação de uma gestão socioambiental.

\subsubsection{O programa agenda ambiental na Administração Pública - A3P}

De acordo com o Princípio 8 da Declaração Rio/92 os Estados devem promover ações que visem a redução e a eliminação de padrões insustentáveis de produção.

Por sua vez, a Agenda 21, documento produzido também na Conferência Rio-92, reforçou a necessidade dos Estados estabelecerem programas voltados ao exame dos padrões insustentáveis de produção e consumo desenvolvidos em suas atividades (ONU, 1992).

Seguindo as recomendações acima, a Administração Pública visando à transformação dos hábitos dos agentes públicos no trato com os recursos naturais, elaborou por meio do Ministério do Meio Ambiente em 1999, o programa Agenda Ambiental na Administração Pública - A3P, para auxiliar os gestores públicos quanto à implementação da responsabilidade socioambiental no desempenho das funções administrativas (MMA, 2009).

O programa é marco introdutório da consciência ambiental no âmbito da Administração Pública, pois visou à união de esforços de todos os entes federativos, englobando os poderes, executivo, legislativo e judiciário com o propósito de arraigar no serviço público atitudes e práticas que minimizem os desgastes que as atividades rotineiras de forma desregrada causam ao meio ambiente (MMA, 2009). 
Trata-se a A3P, de uma ação voluntária, visto que não é uma imposição normativa e sim uma proposta de implementação de práticas sustentáveis no serviço público, que busca a adoção de novos padrões de produção e consumo sustentáveis dentro do governo. O que de acordo com o Ex-Ministro do Meio Ambiente, Carlos Minc, se apresenta como "uma ação que busca a construção de uma nova cultura institucional nos órgãos e entidades públicas” (MMA, 2009, p. 7).

O objetivo da A3P é "sensibilizar os gestores públicos para a importância das questões ambientais, estimulando-os a incorporar princípios e critérios de gestão ambiental em suas atividades rotineiras" (MMA, 2009, p. 30), para promover e incentivar as instituições públicas a adotarem e implantarem ações na área de responsabilidade socioambiental em todas as suas atividades, vislumbrando o engajamento pessoal e coletivo de todos os envolvidos com o serviço público (MMA, 2009).

O programa visa ainda contribuir para com a adoção de novos referenciais de sustentabilidade no âmbito da Administração Pública, reduzir o impacto socioambiental negativo direto e indireto causado pela execução das atividades de caráter administrativo e operacional e contribuir para a melhoria da qualidade de vida (MMA, 2009).

Para o desenvolvimento de suas ações a agenda ambiental visou adotar a política dos 5R's: Repensar, Reduzir, Reaproveitar, Reciclar e Recusar consumir produtos que gerem impactos socioambientais significativos (MMA, 2009).

Visa-se com este princípio levar o cidadão a repensar, se a aquisição ou o serviço é realmente essencial, recusar os materiais que comprometam o meio ambiente e que não sejam biodegradáveis, sempre que possível reaproveitar objetos que podem ser reutilizados por órgãos ou por outras pessoas, reduzir, o lixo, o consumo de energia, água, combustível e reciclar, sempre que possível, os materiais usados pela repartição, transformando-os em novos produtos, evitando-se o desperdício (MMA, 2009).

Com a inserção dos princípios acima delineados, a A3P tendendo constituir seu fim precípuo, que é a implementação da gestão ambiental na Administração Pública, desenvolveu seis principais eixos temáticos para o desenvolvimento da responsabilidade socioambiental na Administração Pública (MMA, 2016): a) Uso racional de recursos naturais e bens públicos; b) Gestão adequada dos resíduos gerados; c) Qualidade de vida no ambiente do trabalho; d) Sensibilização e capacitação dos servidores; e) Licitação Sustentável; f) Construção Sustentável. 
$\mathrm{O}$ ciclo que representa o eixo temático da $\mathrm{A} 3 \mathrm{P}$ pode ser representado conforme figura 2:

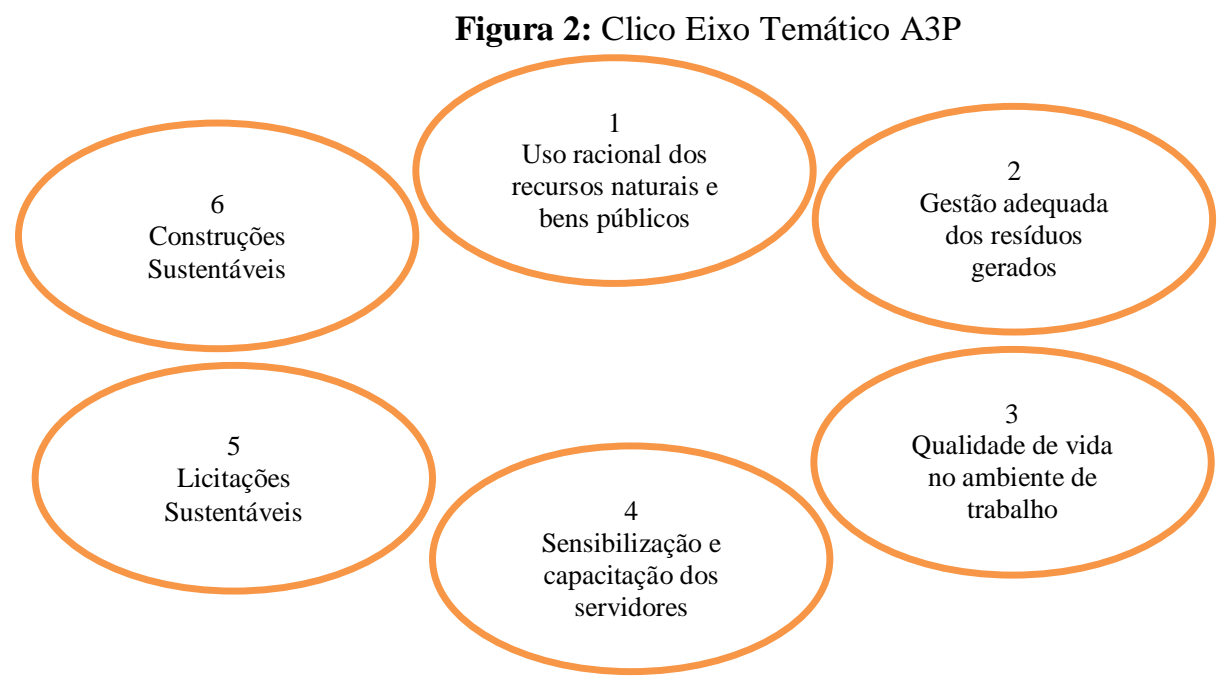

Fonte: Adaptado da cartilha da Agenda Ambiental da Administração Pública, 2016.

Cada eixo temático é apresentado com um rol de sugestões para serem incorporados nos órgãos públicos e segundo Barata, Kligerman e Minayo (2007), com a estruturação dos eixos temáticos, é possível sintonizar a ação governamental, incluir critérios socioambientais e de ecoeficiência em suas atividades, investimentos, compras e contratações.

Assim, a sedimentação do uso racional dos recursos naturais e bens públicos na Administração Pública, visa o uso dos referidos recursos e bens sem desperdícios, incentivando o uso controlado, de modo econômico e racional de todo material de expediente, tais como energia, água, madeira, papel, copos plásticos, dentre outros.

Já para se alcançar a gestão adequada dos resíduos é necessário associá-lo com a política dos 5R'S, ou seja, repensar, reduzir, reutilizar, reciclar e recusar, “dessa forma deve-se pensar em reduzir o consumo e combater o desperdício para só então destinar o resíduo gerado corretamente" (MMA, 2009, p. 39).

Neste caso, fala-se na destinação adequada, por exemplo, de papéis, plásticos, cartuchos, tonners, lixo eletrônico, vidros, metais, pilhas, baterias, dentro outros, visto que sem a destinação correta estes poderão contaminar as áreas no qual está sendo depositado no descarte.

O eixo qualidade de vida no trabalho refere-se às atividades voltadas a qualidade $\mathrm{e}$ o bem-estar do servidor no ambiente em que desenvolve suas funções, que envolve ações 
voltadas para a promoção da saúde, segurança, integração social, desenvolvimento das capacidades, melhoria das condições ambientais, o que permitirá a elevação do grau de satisfação dos servidores no ambiente de trabalho (MMA, 2009).

Com a sensibilização e capacitação dos servidores, busca-se disseminar a importância de se desenvolver postura socioambiental, visto que é a partir da consciência de cada um, quanto à responsabilidade que possui sobre o meio ambiente, que se alcançará a mudança esperada, mas para chegar nesse nível de conscientização é fundamental que os servidores sejam capacitados para desenvolverem suas atividades de forma ambientalmente correta (MMA, 2009).

Barata, Kligerman e Minayo (2007), afirmam que a mudança esperada com a implementação da agenda ambiental somente ocorrerá com a sensibilidade e capacitação dos servidores.

De acordo com o eixo temático que busca a promoção da responsabilidade socioambiental por meio de compras realizadas pela Administração Pública, este deve ser observado quando da realização de licitações para contratações de bens, serviços e obras, adquirindo produtos e serviços que contribuem para a conservação do meio ambiente, "buscando gerar benefícios à sociedade e à economia que reduza os danos ao ambiente natural"(MENEGUZZI, 2011, p. 22).

Para Moura (2010), o eixo da responsabilidade socioambiental por meio de compras é o elemento pelo qual os governos criam oportunidades para inovação e a crescente melhora das tecnologias, estimulando a aplicação generalizada de práticas de produção e consumo sustentáveis em negócios públicos e privados. Este tema será desenvolvido no tópico 2.3.3, quando abordaremos especificamente a respeito das contratações pública sustentáveis.

Por fim, o sexto eixo temático, acrescentado após avaliação da necessidade quanto à sua inclusão, faz referência à Construção Sustentável, constitui-se da necessidade da Administração ao realizar suas obras de observarem diretrizes socioambientais nos edifícios públicos, visto que para suas construções devem pugnar pela colocação de madeiras reutilizadas, estruturas, conforto térmico e acústico além da eficiência energética e estrutura de reuso de água (MMA, 2016).

De forma resumida é possível apresentarmos os eixos temáticos, conforme Quadro 1: 
Quadro 1: Descrição Eixo Temático A3P

\begin{tabular}{|c|c|c|}
\hline Eixo Temático & Implicação & Ações \\
\hline $\begin{array}{l}\text { Uso Racional } \\
\text { de Recursos } \\
\text { Naturais e } \\
\text { Bens Públicos }\end{array}$ & $\begin{array}{c}\text { Evitar o } \\
\text { Desperdício }\end{array}$ & $\begin{array}{l}\text { Usar racionalmente a energia, água, madeira, } \\
\text { copos plásticos, materiais de expediente, etc., } \\
\text { reduzindo o consumo e combatendo o } \\
\text { desperdício. }\end{array}$ \\
\hline $\begin{array}{c}\text { Gestão } \\
\text { Adequada dos } \\
\text { Resíduos Gerados }\end{array}$ & $\begin{array}{l}\text { Destinar } \\
\text { corretamente os } \\
\text { resíduos } \\
\text { gerados }\end{array}$ & $\begin{array}{l}\text { Reduzir a geração de resíduos; descartar e } \\
\text { destinar adequadamente os resíduos gerados. }\end{array}$ \\
\hline $\begin{array}{l}\text { Qualidade de } \\
\text { Vida no } \\
\text { Ambiente de } \\
\text { Trabalho }\end{array}$ & $\begin{array}{c}\text { Facilitar e } \\
\text { satisfazer as } \\
\text { necessidades do } \\
\text { trabalhador } \\
\text { (resultará no } \\
\text { aumento da } \\
\text { produtividade }\end{array}$ & $\begin{array}{l}\text { Melhorar as condições ambientais; promover a } \\
\text { saúde e segurança; observar o acesso aos } \\
\text { portadores de deficiências físicas; incentivar a } \\
\text { integração social; usar e desenvolver as } \\
\text { capacidades humanas, aproveitando as a } \\
\text { habilidades de cada um; dar autonomia para } \\
\text { servidor desempenhar sua função; respeitar a } \\
\text { liberdade de expressão e privacidade pessoal. }\end{array}$ \\
\hline $\begin{array}{l}\text { Sensibilização } \\
\text { e Capacitação }\end{array}$ & $\begin{array}{l}\text { Mudar os } \\
\text { hábitos, } \\
\text { comportamento } \\
\text { e padrões de } \\
\text { consumo }\end{array}$ & $\begin{array}{l}\text { Desenvolver e consolidar nos servidores } \\
\text { sobretudo nos gestores, a consciência cidadã da } \\
\text { responsabilidade socioambiental por meio da } \\
\begin{array}{l}\text { capacitação } \\
\text { apresentações, fóruns...) }\end{array}\end{array}$ \\
\hline $\begin{array}{l}\text { Construções } \\
\text { Sustentáveis }\end{array}$ & $\begin{array}{c}\text { realizar obras } \\
\text { observância } \\
\text { diretrizes } \\
\text { socioambientais } \\
\text { nos edifícios } \\
\text { públicos }\end{array}$ & $\begin{array}{l}\text { Realizar suas construções optando por colocação } \\
\text { de madeiras reutilizadas, estruturas, conforto } \\
\text { térmico e acústico além da eficiência energética e } \\
\text { estrutura de reuso de água. }\end{array}$ \\
\hline
\end{tabular}

Fonte: Adaptado Luiz et al (2013a) adaptado de MMA (2009)

Os gestores públicos tomando consciência da relevância e importância quanto à implementação do programa da A3P no âmbito governamental, passaram a colocá-lo no patamar de ação do governo, destinando ao mesmo, orçamentos públicos específicos, incluindo os programas da agenda ambiental nos Planos Plurianuais, Plano de Diretrizes Orçamentários, dedicando dotação orçamentária própria para execução dos projetos, sedimentando assim, o compromisso governamental com as atividades da gestão socioambiental.

A A3P, conforme já afirmamos, apesar de não possuir força normativa, possui parceria com 175 órgãos e ou instituições ${ }^{3}$ que formalmente aderiram ao programa junto ao Ministério do Meio Ambiente, recebendo em contrapartida apoio técnico para a implementação e operação do programa em seus setores, cursos de capacitação, promoção de eventos, disponibilização de conteúdo didático gratuito, além de serem monitorados e supervisionados pelo Ministério (MMA, 2017).

Devido a importância e o grau de conscientização arraigado ao programa, a relevância do trabalho realizado e os resultados positivos obtidos, a Agenda Ambiental da Administração Pública - A3P, teve reconhecimento da Unesco ao ser premiado como "O

${ }^{3}$ Dados atualizados até 30/08/2017, extraídos do site http://www.mma.gov.br/responsabilidadesocioambiental/a3p/parceiros. Acesso em 04/01/2018. 
melhor dos exemplos" na categoria Meio Ambiente em 2002, chancelando a importância de se valorizar e aderir ao programa como prática de disseminação de política pública ambiental que deu certo, além de estar em harmonia com o princípio da economicidade, o qual se relaciona com o custo-benefício, e com o Princípio da Eficiência, presente no art. 37 da CF/88 (MMA, 2009).

\subsubsection{O plano de logística sustentável - PLS}

De acordo com Sousa (2006) para que a execução de políticas públicas ocorra de forma efetiva e disseminada, é fundamental que estas se desdobrem em programas, planos, metas, sistema de informações, que por muitas vezes são implementadas nos órgãos públicos, com o advento da promulgação de uma lei.

Assim, considerando que a implementação de gestão socioambiental nos órgãos públicos é uma política pública macro, o governo federal com o objetivo de desdobrar e tornar efetiva a política pública socioambiental editou o Decreto nº 7.746/2012 para estabelecer critérios e práticas para a promoção do desenvolvimento nacional sustentável, no qual consta a necessidade de elaboração por parte dos órgãos e instituições de um plano de logística sustentável ${ }^{4}$.

Deste modo, seguindo a orientação normativa acima, o Ministério do Planejamento, Desenvolvimento e Gestão - MPDG instituiu a Instrução Normativa $\mathrm{n}^{\circ}$. 10/2012, com definições, atribuições de responsabilidades para a implementação do plano de logística, orientações quanto ao conteúdo mínimo a ser inserido, temas que deverão ser abrangidos, estrutura dos planos de ações, forma a se construir os indicadores de avaliação de sustentabilidade (BRASIL, 2012).

As orientações esculpidas na IN no. 10/2012 traça os requisitos mínimos de observância pelos órgãos para elaboração do Plano de Logística Sustentável, nada impedindo que cada órgão programe os planos com os requisitos que entendam necessários para a sua execução. Vislumbra-se que com a edição das referidas normas o Plano de Logística Sustentável que antes era uma faculdade passou a ser uma obrigatoriedade a ser cumprida pelos órgãos federais, em razão da imposição de força normativa.

\footnotetext{
${ }^{4}$ Art. 11. Compete à Sisap:

I - propor à Secretaria de Gestão do Ministério do Planejamento, Desenvolvimento e Gestão:

(...)

b) regras para a elaboração dos Planos de Gestão de Logística Sustentável, de que trata o art. 16;
} 
Para Farias (2013), a logística sustentável é um conceito que contribui para o desenvolvimento de uma estratégia de concepção de valor sustentável com objetivo de reduzir o consumo de matéria prima e de emissão de poluentes, nível de transparência e responsabilidade socioambiental, desenvolvimento de novas tecnologias e o atendimento às demandas de mercado e da sociedade em que se insere.

Segundo Oda (2009), a logística pode ser sustentável, se pensada e desenvolvida como uma gestão estratégica das organizações para no conjunto das atividades reduzir danos e impactos negativos.

$\mathrm{O}$ art. $3^{\circ}$ da Instrução Normativa acima mencionada traz o conceito definido e claro sobre o que é o Plano de Logística Sustentável, conforme transcrição abaixo:

\footnotetext{
Os PLS são ferramentas de planejamento com objetivos e responsabilidades definidas, ações, metas, prazos de execução e mecanismos de monitoramento e avaliação, que permitem ao órgão ou entidade estabelecer práticas de sustentabilidade e racionalização de gastos e processos na Administração Pública. (Art. 3', IN No. 10/2012).
}

De acordo com os conceitos apresentados, pôde extrair que os planos de logística sustentável além de estarem correlacionados aos critérios ambientais, ainda estão aliados aos de eficiência e economia nas atividades desempenhadas pelos serviços públicos.

Nesta seara, a IN nº. 10/2012, determinou que os Planos de Logística Sustentável devem trazer de forma atualizada: o inventário dos bens e materiais do órgão, correlacionada com a identificação de bens e materiais similares que causem menor impacto ambiental para substituição dos mesmos; apresentar práticas de sustentabilidade e de racionalização do uso de materiais e serviços; definir os responsáveis, metodologia de implementação e avaliação do PLS; e desenvolver ações de divulgação, conscientização e capacitação para execução das metas traçadas (MPOG, 2012). ${ }^{5}$

Trouxe a referida Instrução Normativa, referências às práticas de sustentabilidade e racionalização do uso de materiais e serviços que deverão ser minimamente contemplados (MPOG, 2012) ${ }^{6}$ :

1. material de consumo compreendendo, pelo menos, papel para impressão, copos descartáveis e cartuchos para impressão;

2. energia elétrica; água e esgoto;

\footnotetext{
${ }^{5}$ Art. $3^{\circ}$ da IN N ${ }^{\circ}$ 10/2012 do MPOG

${ }^{6}$ Art. $8^{\circ}$ da IN N ${ }^{\circ}$. 10/2012 do MPOG
} 
3. coleta seletiva;

4. qualidade de vida no ambiente de trabalho;

5. compras e contratações sustentáveis, compreendendo, pelo menos, obras, equipamentos, serviços de vigilância, de limpeza, de telefonia, de processamento de dados, de apoio administrativo e de manutenção predial;

6. deslocamento de pessoal, considerando todos os meios de transporte, como foco na redução de gastos e de emissões de substâncias poluentes.

Exige ainda a Instrução Normativa que as instituições/órgãos devem construir planos de ações para cada uma das temáticas contemplada no PLS, identificando o objetivo, detalhando as ações propostas, definindo as unidades e áreas envolvidas na implementação, os responsáveis pela execução de cada ação, assim como o seu cronograma de implementação e as metas a serem alcançadas, além de estimar a previsão de recursos financeiros, humanos, instrumentais necessários para o desenvolvimento das ações (MPOG, 2012). ${ }^{7}$

Caso os órgãos entendam pela necessidade de acrescentar temas ao seu Projeto de Logística Sustentável, será necessária a inclusão de indicadores contendo nome, fórmula de cálculo, fonte de dados, metodologia de apuração e periodicidade de apuração (MPOG, 2012). Os indicadores, para Bellen (2006), são necessários para mensuração e medição do desenvolvimento sustentável, visto que permite a avaliação quanto ao alcance das metas estabelecidas e ou correção dos desvios detectados.

A Instrução Normativa elenca em seu art. 11 algumas ações governamentais que podem ser utilizadas como parâmetros para o desenvolvimento do PLS, tal como a Agenda Ambiental na Administração Pública - A3P e exige ainda, a obrigação das instituições de publicar semestralmente as metas conquistadas e os resultados obtidos, com as ações traçadas, em site do próprio órgão (MPOG, 2012).

Observa-se que referida exigência anda em consonância com o Princípio da Publicidade exigida no art. 37 da CF/88 e com a Lei de Acesso à Informação, corroborando com a transparência e accountability exigidos para as coisas públicas, bem essencial do povo.

O passo a passo para o desenvolvimento e implementação do Plano de Logística Sustentáveis pode ser bem representada conforme figura 3:

\footnotetext{
${ }^{7}$ Art. $9^{\circ}$ da IN No $10 / 2012$ do MPOG
} 
Figura 3: Passos para construção do Plano de Logística Sustentável

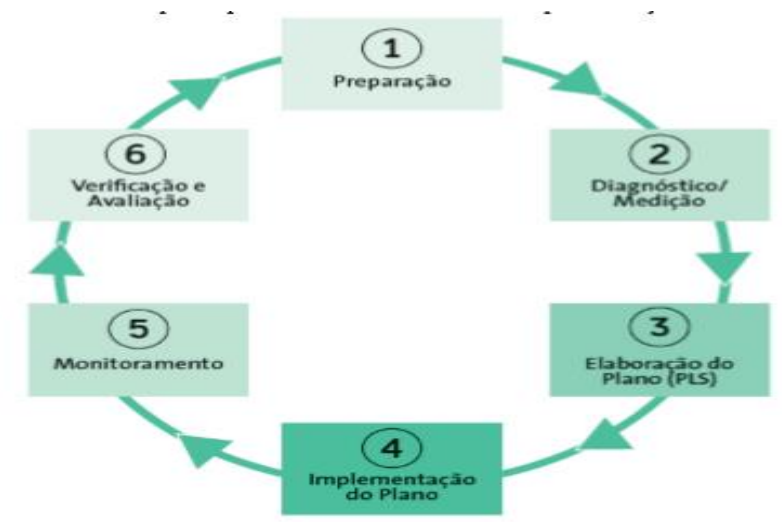

Fonte: ICLEI, 2013

Segundo a ICLEI (2013) ${ }^{8}$, principal organização que oferece apoio aos governos para o desenvolvimento de políticas de sustentabilidade, para que a implementação do PLS ocorra, é necessário observar o ciclo representado na figura 3, que nada mais é que a representatividade das exigências encartas na IN No. 10/2012.

De acordo ainda com a ICLEI (2013), as instituições devem primeiramente criar uma Comissão Gestora do PLS, formada por servidores de áreas diversificadas de conhecimento, para realização do diagnóstico e levantamento do inventário dos bens e materiais de consumo do órgão, identificando as possíveis ações para melhoria do quadro diagnosticado, para após, elaborar o Plano de Logística Sustentável, com suas temáticas e indicadores, para enfim, realizar sua implementação com adoção das práticas previstas nas ações propostas.

Após a implementação do PLS, fundamental que se faça o monitoramento das ações, possibilitando a avaliação dos resultados aferidos, cujo procedimento é recomendado que seja realizado semestralmente pela comissão gestora, o que irá possibilitar a identificação dos desvios e a necessidade de inclusão de novas ações ou

\footnotetext{
8“O ICLEI é a principal associação mundial de governos locais dedicados ao desenvolvimento sustentável, cuja rede global conecta mais de 1.500 governos de estados e cidades de diversos portes, em mais de 100 países. Movido pela causa de mobilizar os governos locais para construir cidades mais sustentáveis, o ICLEI oferece apoio para que desenvolvam suas políticas e ações pela sustentabilidade. Orienta-se pela premissa básica de que iniciativas elaboradas e dirigidas localmente podem fornecer uma maneira eficaz e economicamente eficiente para alcançar objetivos locais, nacionais e globais." http://sams.iclei.org/quem-somos/o-iclei.html
} 
melhoramento das ações que se encontram em curso, para enfim, se chegar na avaliação que ocorre com a apresentação do relatório de acompanhamento do PLS, evidenciando o desempenho dos órgãos (ICLEI, 2013).

Considerando que o PLS é uma ação obrigatória a todas as esferas administrativas, o Poder Judiciário, através do Conselho Nacional de Justiça criou mecanismos próprios para a implementação do PLS em seu âmbito, com mecanismos, e exigências para sua elaboração e prática, conforme será abordado no tópico 2.4.

\subsubsection{Contratações públicas sustentáveis}

É cediço que a Administração Pública no exercício da função de administrador da gerência da coisa pública, deve obediência a princípios e objetivos estabelecidos na Constituição Federal, em estrito cumprimento ao Princípio da Legalidade, onde lhe compete a fazer somente o que a lei lhe autoriza.

E de acordo com o inciso XXI, do art. 37 da Constituição Federal, as contratações realizadas pela Administração Pública devem ser precedidas mediante processo de licitação pública, que assegurem contratações que garantem a isonomia na participação dos interessados e a seleção da proposta mais vantajosa para à Administração ${ }^{9}$ (BRASIL, 1993).

Ciente do poderio administrativo quanto às questões que envolvem suas aquisições, as contratações públicas tiveram uma atenção especial, conforme já mencionado no item 2.3.1 que tratou da A3P, para as contratações sustentáveis, se transformando inclusive em um dos eixos a serem observados para implementação do programa no âmbito governamental, merecendo destaque, visto que envolve a aquisição de todos os produtos, serviços e obras contratadas pela Administração Pública.

Segundo Mirelles (2003, p. 264), a contratação pública:

Como procedimento, desenvolve-se através de uma sucessão ordenada de atos vinculantes para a Administração e para os licitantes, o que propicia igual oportunidade a todos os interessados e atua como fator de eficiência e moralidade nos negócios administrativos.

\footnotetext{
${ }^{9}$ Art. $3^{\circ}$ da Lei 8666/93, quando instituído, trazia apenas as duas finalidades mencionadas.
} 
O Governo Federal, a quem compete legislar de forma geral sobre licitações, buscando instrumentalizar a obrigatoriedade quanto à promoção do desenvolvimento sustentável, conforme compromissos assumidos em nome da sustentabilidade (BARKI, 2011), publicou em 2010 a Lei 12.349 que alterou o artigo $3^{\circ}$ da Lei de Licitações, para tornar obrigatório a todos os entes federados a observância quanto às contratações sustentáveis, consagrando um dos objetivos fundamentais da $\mathrm{CF} / 88$, que é a preservação do meio ambiente.

Para Bliacheris (2011), as licitações sustentáveis nada mais é que uma política pública para a preservação do meio ambiente. Introduzir critérios de sustentabilidade ambiental nas contratações públicas é uma resposta a um anseio social de viver com menor impacto no meio ambiente.

Magalhães (2013) também define as licitações sustentáveis como uma política, pois as contratações públicas devem levar em consideração critérios de sustentabilidades, fundamentados no desenvolvimento econômico e social e na conservação do meio ambiente.

Além de responsável pela adoção de políticas públicas que garantem a sustentabilidade e a preservação do meio ambiente, compete ao próprio Poder Público assegurar padrões de produção e de consumo sustentáveis (Objetivo 12, Agenda 21) promovendo práticas de compras públicas sustentáveis de acordo com as políticas desenvolvidas para a disseminação de modos de produção sustentáveis no país.

Ocorre que esta não é uma inovação legislativa do Brasil e sim uma forma de se afirmar o pacto estabelecido pelo país, quando participou da Cúpula Mundial sobre Desenvolvimento Sustentável de Johanesburgo, em 2002, onde ficou estabelecido que competem as autoridades públicas desenvolverem ações de contratações públicas que possam favorecer a difusão de mercadorias e serviços favoráveis ao meio ambiente (BRASIL, 2010).

Em 2012 o art. $3^{\circ}$ da Lei 8.666/93 foi alterado pelo Decreto 7.746/2012, para se estabelecer critérios e diretrizes em busca da promoção do desenvolvimento nacional sustentável por meio das contratações realizadas pela Administração Pública direta, autárquica e fundacional. Competindo a cada Estado e Município, estabelecerem suas próprias diretrizes sobre o assunto (BRASIL, 2012).

A contratação pública sustentável, também denominada de compras verdes, é uma ferramenta de gestão socioambiental, voltada diretamente para os entes públicos, visto que 
além de regulador da matéria é um consumidor com grande poder de compra no mercado. Assim, ao exigir que as empresas que prestem serviços e oferecem produtos para a Administração Pública, sigam a linha do sustentável, incute uma mudança de comportamento para o tripé que se busca com a sustentabilidade, ou seja, aquilo que é socialmente desejável, economicamente viável e ecologicamente sustentável (SILVA, 2012).

Tem-se que a Administração Pública no ato de suas contratações, poderão exigir das empresas prática das seguintes diretrizes: baixo impacto sobre recursos naturais; preferência para materiais, tecnologias e matérias-primas de origem local; maior eficiência na utilização de recursos naturais como água e energia; maior geração de empregos, preferencialmente com mão de obra local; maior vida útil e menor custo de manutenção do bem e da obra; uso de inovações que reduzam a pressão sobre recursos naturais; bem como, a origem ambientalmente regular dos recursos naturais utilizados nos bens, serviços e obras (BRASIL, 2012).

Para alcance das diretrizes estabelecidas, pode a Administração exigir no ato do instrumento convocatório, editais de licitação, que as empresas licitantes apresentem selos, certificações ou rótulos ambientais, emitidos ou reconhecidos por instituição pública oficial ou credenciada, tais como: FSC, Cerflor, PBE, Selo Procel, Programa Selo Verde e Selo SisOrg (MMA, 2016)

A inserção do referido dispositivo nas normas infra legais, é de tal monta, que trouxe inclusive mudança de comportamento ao próprio Tribunal de Contas, órgão imbuído de competência para controle externo da atividade administrativa, visto que passaram a incluir as questões ambientais em suas auditorias, buscando com sua prática além de fiscalizar, incentivar as ações do governo com o meio ambiente.

\subsection{Instrumentos de Gestão Socioambiental no Poder Judiciário}

$\mathrm{O}$ art. 225 da Constituição Federal é cristalino ao estabelecer que compete ao poder público e a coletividade o dever de defender e preservar o meio ambiente para a presente e as futuras gerações (BRASIL, 1988).

Neste mister, o Poder Judiciário na qualidade de poder público, possui o dever de disseminar práticas e padrões de gestão socioambiental, por ser agente transformador de 
novos padrões de cultura e costumes, servindo suas ações como referências a serem seguidas pela sociedade.

Contudo, a temática meio ambiente nas atividades administrativas do Poder Judiciário teve maior atenção e relevância após a criação do Conselho Nacional de Justiça - CNJ, o que ocorreu com a Reforma do Poder Judiciário Brasileiro em 2004, por meio da Emenda Constitucional $\mathrm{n}^{\circ} .45$, cujo papel precípuo é planejar e padronizar as atividades do Poder Judiciário, devendo publicar semestralmente relatórios estatísticos referentes à atividade jurisdicional em todo o país, conferindo controle e transparência administrativa, financeira e processual das ações por ele desenvolvidas.

Segundo a Constituição Federal (1988), dentre as incumbências do CNJ, está a de definir planos, metas e programas de avaliação institucional, voltados para as áreas de Direito Humanos, Tecnologia, Gestão Institucional, Meio Ambiente, dentre outras.

Na temática Meio Ambiente o CNJ tem envidado esforços para fomentação da execução de ações voltadas para sustentabilidade nos Tribunais. Consciente de seu papel social lançou o programa CNJ Ambiental, que de acordo com o próprio CNJ (2010), é ferramenta de auxílio aos Tribunais, cujo objetivo é o fortalecimento e a harmonização de ações, programas e projetos socioambientais no Poder Judiciário, além de engajar os servidores e magistrados sobre assuntos e demandas socioambiental e realizar pesquisas e estudos que servem de subsídio para formulação de diretrizes de política socioambiental no Poder Judiciário.

Assim, imbuído das atribuições que lhe foi conferida pela Constituição Federal, normatizou a política ambiental no Poder Judiciário por meio de Resoluções e Recomendações, que abordam questões socioambientais, planejamento, gestão estratégica e definem responsabilidades social e ambiental.

Nesta seara, abordaremos nas subseções subsequentes os principais instrumentos normativos elaborados pelo CNJ que traçam diretrizes socioambientais de aplicação no Poder Judiciário.

2.4.1 Recomendação CNJ $n^{\circ}$. 11 de 22 de maio de 2007: recomenda aos Tribunais que adotem políticas púbicas que visem o ambiente ecologicamente equilibrado

A discussão mundial sobre o aquecimento global, a influência do poder público na atividade econômica nacional, o papel preponderante da Administração Pública na criação 
de novos padrões de consumo e produção, a norma esculpida no art. 225 da CF que impõe ao poder público e a coletividade o dever de defender e preservar o meio ambiente para as presentes e futuras gerações, foram fatores levados em consideração para a edição da Recomendação imposta a todos os Tribunais relacionados nos art. 92 da Constituição Federal de 1988 (CNJ, 2012).

A Recomendação CNJ nº 11 de 22 de maio de 2007 é documento que externalisa a preocupação do $\mathrm{CNJ}$ com as questões socioambientais, sendo este considerado o marco na esfera judiciária, visto que é o primeiro documento a ser elaborado e disseminado pelo Conselho, com indicações de como todos os Tribunais brasileiros devem desenvolver suas atividades com o pensamento voltado para a sustentabilidade (CNJ, 2012).

O CNJ ao editar a Recomendação n ${ }^{\circ}$. 11/2007 tinha como objetivo precípuo, levar os Tribunais a adotarem "políticas públicas que possibilitem a formação e recuperação de um ambiente ecologicamente equilibrado, além da conscientização dos próprios servidores e jurisdicionados sobre a necessidade de efetiva proteção ao meio ambiente" (CNJ, 2012, p. 7 e 8$)$.

Mas não só, pretendia ainda o CNJ que os Tribunais desenvolvessem um planejamento voltado para elaboração de atividades e ou programas que auxiliassem na preservação e recuperação do meio ambiente, devendo para tanto, fixar metas anuais a serem alcançadas e desenvolver ações que permitem o acompanhamento das medidas indicadas.

Para o desenvolvimento das atividades acima, exigiu o CNJ que cada Tribunal criasse comissões ambientais designadas precipuamente para o referido fim (CNJ, 2007), o que reforça que o assunto deve ser visto e tratado de forma específica e prioritária por cada Tribunal.

O CNJ com a Recomendação, de forma a incentivar os Tribunais a adotarem medidas socioambientais, elencou um rol mínimo de atividades que devem ser observadas e implementadas na atividade diária do serviço jurisdicionado, tais como:

a) utilização de papel reciclado e não clorado nos impressos do Poder Judiciário, sejam de natureza administrativa ou processual;

b) instituição da coleta seletiva de resíduos, destinando recipientes individuais para plástico, papel, metal e vidro, e a ulterior doação do material coletado a entidades assistenciais que se responsabilizem pela correta utilização do material para a devida reciclagem;

c) aquisição de impressoras que imprimam, automaticamente, em frente e verso; 
d) aquisição de bens e materiais de consumo que levem em consideração o tripé básico da sustentabilidade: ambientalmente correto, socialmente justo e economicamente viável;

e) utilização sustentável da energia e dos combustíveis; e

f) utilização de edifícios com observância da proteção ao meio ambiente. (CNJ, 2007)

O rol acima é meramente exemplificativo, podendo cada Tribunal por meio de estudos realizados pela comissão ambiental, adotarem tantas quantas medidas e ações que entenderem necessárias para o desenvolvimento da sustentabilidade em seu âmbito.

Chama-se atenção para o fato que o documento ora em análise, não possui o caráter de força normativa dotada de coercibilidade, visto que como o próprio nome descreve, trata-se de uma recomendação aos Tribunais, podendo serem observadas ou não, a depender do crivo e critérios de cada um, mas foi a partir de tal iniciativa que os Tribunais passaram adotar a temática e externar a preocupação com o meio ambiente nas atividades desenvolvidas no Poder Judiciário, conforme podemos constatar na figura 4, apresentada no primeiro relatório socioambiental divulgado pelo $\mathrm{CNJ}$ :

Figura 4: Relatório Socioambiental CNJ

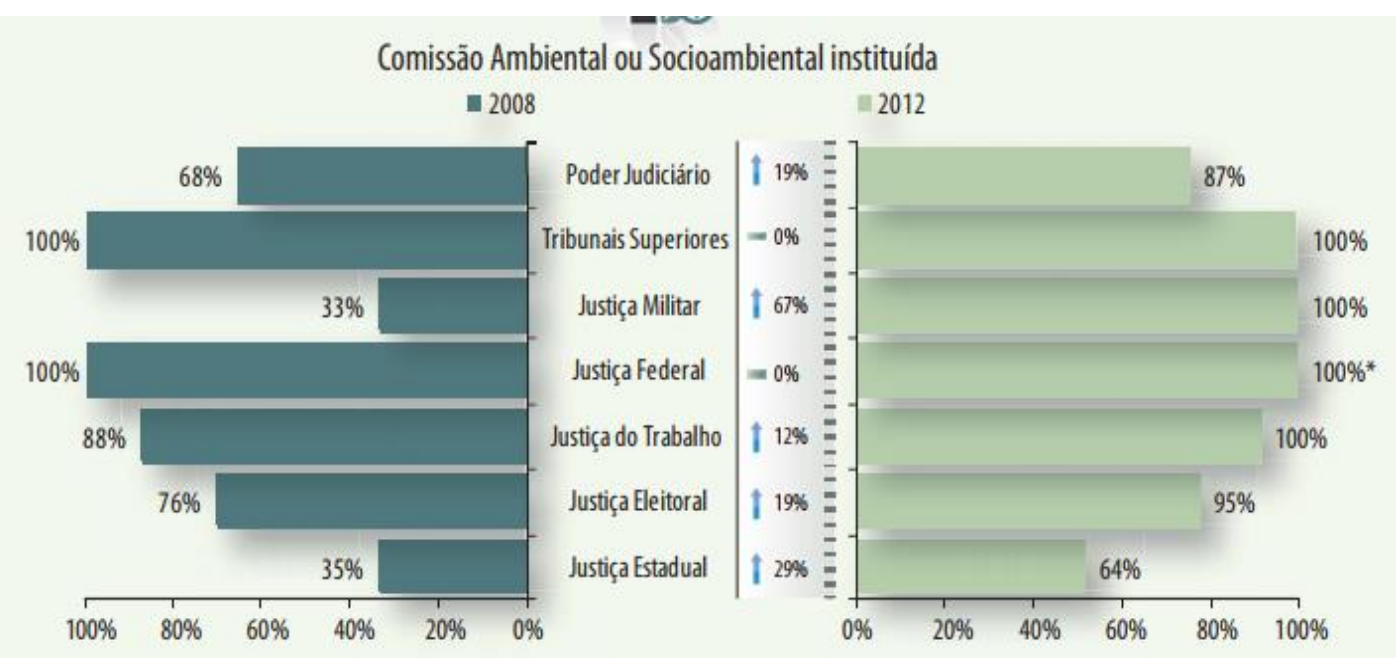

Fonte: Departamento de Pesquisa Judiciária CNJ, 2010.

Com base nos dados revelados pela figura 4, é possível perceber que nos períodos subsequentes ao lançamento da Recomendação, compreendido entre 2008 a 2012, teve um elevado índice à adesão por parte dos Tribunais, o que demonstra a relevância da Recomendação para a temática estudada na seara do Poder Judiciário, que passaram a adotar políticas públicas visando à formação e recuperação de um ambiente ecologicamente equilibrado (CNJ, 2010). 
2.4.2 Recomendação CNJ n ${ }^{\circ} .27$ de 16 de dezembro de 2009: recomenda aos Tribunais que adotem medidas que promovam acessibilidade de deficientes às suas dependências

De acordo com o CNJ (2012), a acessibilidade é uma garantia ao pleno exercício de direitos de todos os cidadãos, devendo o Poder Judiciário na prestação de seus serviços desenvolver suas atividades de forma a conscientizar seus servidores e jurisdicionados da importância da inclusão social nas diretrizes traçadas para a sustentabilidade e nas demandas socioambiental.

Neste mister, o Conselho Nacional de Justiça, visando incutir em todos os Tribunais a inclusão social, por meio da acessibilidade das pessoas com deficiência física, recomendou que os mesmos adotassem medidas que garantissem a remoção de barreiras físicas, arquitetônicas, de comunicação e atitudinais com o propósito de promover o acesso de pessoas com deficiência em suas dependências (CNJ, 2009).

Para alcançar o referido objetivo, aconselha o CNJ que o Poder Judiciário institua comissões próprias em suas unidades para trabalhar o aspecto da acessibilidade em seu âmbito, competindo às referidas comissões planejar, elaborar e acompanhar projetos, que fixem metas direcionadas à promoção da acessibilidade para pessoas com deficiências no período de um ano, promovendo assim, o acesso dos portadores de deficiência à justiça (CNJ, 2012).

A Recomendação $n^{\circ}$. 27/2009 elenca algumas ações voltadas para a acessibilidade a serem observadas e implementadas nos órgãos e unidades judiciais como: construção de rampas, adequação de sanitários, instalação de elevadores, reserva de vagas em estacionamento, instalação de piso tátil direcional e de alerta, sinalização sonora para pessoas com deficiência visual, bem como sinalizações visuais acessíveis a pessoas com deficiência auditiva, pessoas com baixa visão e pessoas com deficiência intelectual, adaptação de mobiliário, portas e corredores em todas as dependências e em toda a extensão; permissão de entrada e permanência de cães-guias em todas as dependências dos edifícios e sua extensão, habilitação de servidores em cursos e oficiais de Linguagem Brasileira de Sinais custeados pela Administração e nomeação de tradutor e intérprete de Linguagem Brasileira de Sinais, garantia da pessoa com deficiência auditiva participar do processo oralizado se assim o preferir, acompanhado de intérprete, aquisição de impressora 
em braille, reserva de vagas nos concursos, prioridade na tramitação de processos administrativos, dentre outros (CNJ, 2009).

Para o CNJ a inclusão social é uma demanda socioambiental que deve ser abalizada e observada pelos servidores garantindo assim o acesso à justiça das pessoas portadoras de deficiência.

2.4.3 Resolução CNJ n. ${ }^{\circ} 198$ de $1^{\circ}$ de julho de 2014: dispõe sobre o planejamento e a gestão estratégica no âmbito do Poder Judiciário

A Resolução CNJ 198/2014, possui o condão de delinear o planejamento e a gestão estratégica a serem adotados pelo Poder Judiciário no sexênio compreendido entre 2015-2020, com ênfase nos seguintes componentes: visão, valores e macrodesafios do Poder Judiciário (CNJ, 2014).

De acordo com o CNJ (2014) a responsabilidade socioambiental, encontra-se dentro do campo de atributos de valores para a sociedade, cujo macrodesafio é a garantia dos direitos e cidadania, buscando-se com estratégia "atenuar as desigualdades sociais e garantir os direitos de minorias, observando-se, para tanto, práticas socioambientais sustentáveis e uso de tecnologia limpa" (CNJ, 2014, Glossário, p. 2)

Assim, restou designado que todos os órgãos que compõem o judiciário deverão pensar e desenvolver suas ações para os anos de 2015 a 2020 com um olhar voltado para a sustentabilidade nas ações a serem desenvolvidas.

E nos termos do art. $7^{\circ}$ da Resolução, a execução das estratégias propostas é de responsabilidade de magistrados de primeiro e segundo graus, conselheiros, ministros e serventuários, cuja promoção e divulgação devem ocorrer por meio de eventos voltados para a temática.

2.4.4 Resolução CNJ nº 201 de 3 de março de 2015: dispõe sobre a criação dos núcleos socioambientais no Poder Judiciário e implanta o plano de logística sustentável

Para a edição da Resolução $n^{\circ}$. 201/2015, o CNJ levou em consideração dispositivos de diversas normas do ordenamento para compor, segundo o Departamento de Pesquisas Judiciárias do CNJ (2016), “o maior grau de amadurecimento da temática 
inserida no planejamento estratégico do Poder Judiciário" alcançando um novo patamar no que tange à responsabilidade socioambiental.

Destarte, é perceptível da leitura dos próprios considerando apontados na Resolução, a preocupação em se abordar e abarcar o maior número de dispositivos legais como referência para elaboração da normativa num único documento, (CNJ, 2015), conforme podemos observar pela descrição do arcabouço jurídico abaixo transcrito:

a) Art. 170, IV da Constituição Federal que trata da defesa do meio ambiente;

b) Art. 225 que estabelece que todos tem o direito ao meio ambiente ecologicamente equilibrado;

c) Art. $3^{\circ}$ da Lei $8.666 / 93$ que trata das normas para licitações e contratos administrativos;

d) Decreto 7.746/212 que regulamenta o próprio art. $3^{\circ}$ da lei de licitações para estabelecer critérios, práticas e diretrizes para promoção do desenvolvimento nacional sustentável;

e) Lei 12.187/2009 que institui a Política Nacional de Mudança do Clima;

f) Lei 12.305/2010 que institui a Política Nacional de Resíduos Sólidos e Decreto $\mathrm{n}^{\circ}$. 7.407 que regulamenta a supracitada lei;

g) Resolução CNJ 114/2010 que dispõe sobre planejamento, execução e monitoramento de obras;

h) Resolução CNJ 198/2014 que dispõe sobre o Planejamento de Gestão Estratégica no âmbito do Poder Judiciário;

i) Recomendações CNJ 11/2007 e 27/2009 que tratam da inclusão de práticas socioambientais nas atividades rotineiras dos Tribunais;

j) Instruções Normativas CNJ 1/2010 e 10/2010 que estabelecem regras para elaboração dos Planos de Gestão de Logística Sustentável de que trata o Decreto 7.746/2012;

k) e Recomendações do Tribunal de Contas da União, contidas no Acórdão 1.752/2011 que decidiu sobre as medidas de eficiência e sustentabilidade por meio do uso racional de energia, água e papel pela Administração Pública.

Insta salientar, que todos os dispositivos legais levados em consideração para elaboração da presente Resolução já foram abordados neste capítulo da dissertação. 
Assim, a Resolução $n^{\circ}$. 201 do CNJ, dispõe sobre a criação e competências das unidades ou núcleos socioambientais nos órgãos e conselhos do Poder Judiciário e da implantação do Plano de Logística Sustentável nas referidas unidades (CNJ, 2015).

De acordo com a Resolução (CNJ, 2015), se faz necessário instituir caráter permanente às unidades ou núcleos socioambientais para possibilitar o desenvolvimento do planejamento, implementação e monitoramento das metas estabelecidas, facilitando assim, a avaliação quanto ao cumprimento dos indicadores de desempenho dispostos na própria Resolução ${ }^{10}$.

Compete ainda às unidades ou núcleo socioambientais, estimular no âmbito do Tribunal "a reflexão e a mudança quanto aos padrões de compra, consumo e gestão documental dos órgãos do Poder Judiciário, bem como do corpo funcional e força de trabalho auxiliar de cada instituição" (CNJ, 2015, Art. 5) devendo para tanto, fomentar ações que estimulem:

\footnotetext{
I - o aperfeiçoamento contínuo da qualidade do gasto público;

II - o uso sustentável de recursos naturais e bens públicos;

III - a redução do impacto negativo das atividades do órgão no meio ambiente com a adequada gestão dos resíduos gerados;

IV - a promoção das contratações sustentáveis;

V - a gestão sustentável de documentos, em conjunto com a unidade responsável;

VI - a sensibilização e capacitação do corpo funcional, força de trabalho auxiliar e de outras partes interessadas; e

VII - a qualidade de vida no ambiente de trabalho, em conjunto com a unidade responsável." (CNJ, 2015, Art. 6º
}

Em consonância com a Política Nacional de Resíduos Sólidos, propõe a Resolução que os órgãos e ou unidades judicias promovam a coleta seletiva, reciclagem de materiais e destinação do material reutilizável a catadores de resíduo, evitando-se desperdícios e fomentando o consumo consciente do uso sustentável dos recursos naturais e bens públicos (CNJ, 2014).

Conforme já dito acima, além da obrigatoriedade da criação de unidades ou núcleos socioambientais nos órgãos do Poder Judiciário, a Resolução tornou obrigatória ainda, a criação de Planos de Logística Sustentável no âmbito de cada Tribunal, fazendo cumprir desta forma, a exigência imposta no Decreto Federal $n^{\circ}$. 7.746/2012, que estabeleceu critérios e práticas para a promoção do desenvolvimento nacional sustentável, a todos os órgãos federais.

\footnotetext{
${ }^{10}$ Art. $4^{\circ}$ da Resolução CNJ no $.201 / 2015$
} 
A Resolução CNJ nº. 201/2015, praticamente seguiu os parâmetros fixados no Decreto acima mencionado, pois designou que os Tribunais constituíssem comissão gestora, composta por no mínimo 5 (cinco) servidores, devendo obrigatoriamente essa comissão ser multidisciplinar, sendo um servidor da unidade ou núcleo socioambiental e os demais da unidade de planejamento estratégico e da área de compras ou aquisições do órgão ou conselho em que estejam inseridos, para elaborar, monitorar, avaliar e revisar o PLS (CNJ, 2015).

O PLS-PJ deve ser elaborado com objetivos e responsabilidades bem definidas voltadas para ações, metas, prazos de execução, mecanismos de monitoramento e avaliação de resultados que possibilitem o acompanhamento das práticas de sustentabilidade, com a observância dos requisitos mínimos exigidos para a avaliação do desempenho ambiental e econômico que deve abranger (CNJ, 2015):

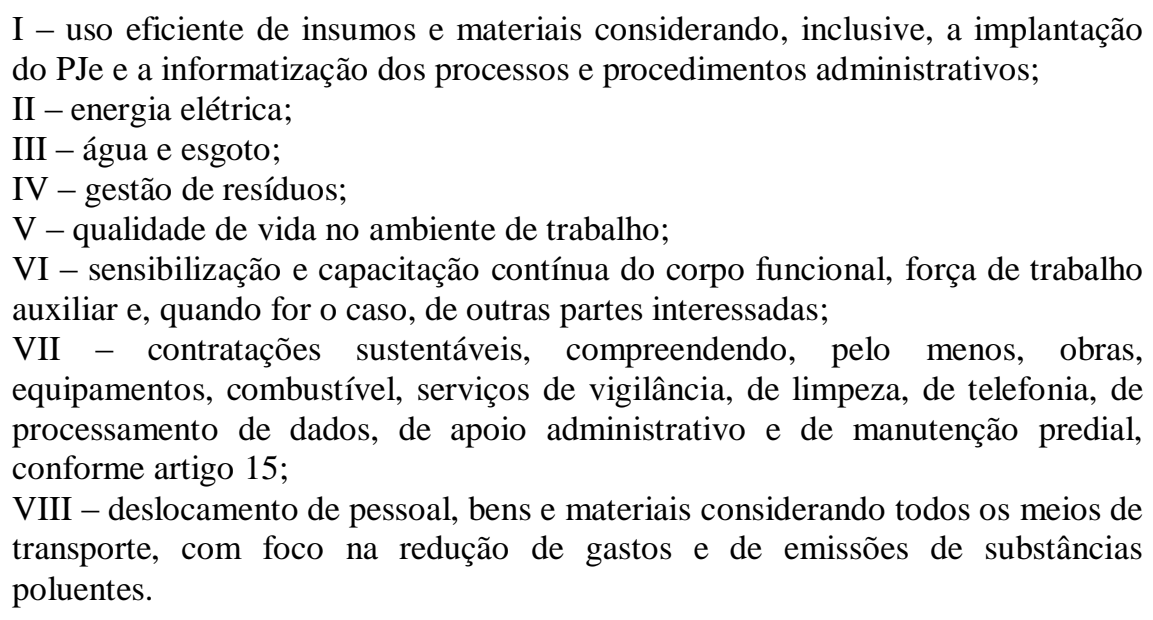

Estabeleceu ainda a resolução que cada ação acima citada, deverá ser formalizada em processo administrativo próprio, devendo ser criado planos individualizados com (CNJ, 2015, art. 18):

a) objetivo do plano de ação;

b) detalhamento de implementação das ações, unidades e áreas envolvidas na implementação e respectivos responsáveis;

c) metas a serem alcançadas;

d) e cronograma de implementação das ações e previsão de recursos financeiros, humanos, instrumentais. 
Para o sucesso das ações será necessário que os órgãos ou unidades fomentem a capacitação dos servidores para conhecimento do que está sendo proposto e disseminação da prática das ações estabelecidas.

A Resolução CNJ nº 201 (2015) em seus anexos ainda contemplam 15 indicadores como referência para avaliação do desempenho ambiental e econômico do PLS-PJ categorizados entre indicadores, definição, unidade de medida e periodicidade do consumo para os itens: papel, copos descartáveis, água envasada em embalagem plástica, impressão, telefonia, energia elétrica, água e esgoto, gestão de resíduos, reformas, limpezas, vigilância, veículos, combustível, qualidade de vida e capacitação social ambiental. Nada obstante que o rol seja acrescido, ficando a critérios de cada órgão ou unidade jurisdicional.

Vislumbra-se ainda na Resolução a apresentação de sugestões de práticas de sustentabilidade, racionalização e consumo quanto à aquisição de matérias e à contratação de serviços, demonstrando na prática como a economia pode ser realizada no desempenho das atividades cotidianas, disseminando o uso correto dos recursos naturais e bens públicos no ambiente de trabalho.

Por fim, determinou a referida Resolução, que o PLS-PJ deve ser publicado no sítio eletrônico de cada órgão dando extrema publicidade ao ato, assim como os resultados obtidos, que deverão ser publicados no final de cada semestre com um balanço das metas e resultados, para ao final de cada ano ser elaborado um relatório de desempenho que subsidiará o Balanço Socioambiental do Poder Judiciário a ser elaborado pelo CNJ (CNJ, 2015).

O acompanhamento e monitoramento dos resultados alcançados com o PLS-PJ é fundamental para se consolidar os resultados obtidos, melhorar o desempenho dos indicadores estratégicos e assimilar as ações que necessitam ser ampliadas ou modificadas para o ano seguinte.

A má utilização dos recursos naturais demandaram da sociedade civil tomada de atitudes que minimizassem os impactos que as atividades em prol do desenvolvimento vinham causando ao meio ambiente, gerando movimentos ambientais e debates mundiais que exigiam atitudes a favor da sustentabilidade socioambiental.

Como resultado das discussões competiu ao poder público, em face de suas atribuições legais, a implementação de políticas públicas que abalizassem diretrizes voltadas para uma gestão socioambiental por parte de toda sociedade civil. 
Nesta seara, diante das características predominantes da Administração Pública, imbuída do papel fundamental na adoção de iniciativas que proporcionem a incorporação de programas, projetos e ações que envolvam o engajamento de todos para fomentação de práticas sustentáveis, estabeleceu-se medidas a serem adotados por todos os seus gestores.

Assim, o Poder Judiciário não se furtou de suas obrigações, visto que, por meio de normas e recomendações exigiu que todos os Tribunais do país observassem as exigências quanto a implementação de práticas sustentáveis em suas atividades.

Deste modo, tendo em mente a proposta da pesquisa que é analisar o processo de institucionalização da gestão sustentável no Tribunal de Justiça do Tocantins, buscou-se reflexões conceituais sobre sustentabilidade, gestão sustentável, análise de políticas públicas e programas adotadas no Brasil, além de analisar como o Poder Judiciário inseriu a temática em sua agenda institucional. 


\section{METODOLOGIA}

Este capítulo visa delinear os métodos e procedimentos utilizados nesta pesquisa.

Dessa forma, serão apresentados o enquadramento teórico metodológico assim como os aspectos operacionais, relacionados à coleta e análise dos dados, descrevendo os instrumentos utilizados para realização da pesquisa.

\subsection{Enquadramento Teórico-Metodológico}

A pesquisa é uma prática de constante busca, uma atividade de aproximação da realidade que não se esgota, fazendo-se uma combinação entre teoria e dados (MINAYO, 1993).

Para Gil (1999, p. 42) “o objetivo fundamental da pesquisa é descobrir respostas para problemas mediante o emprego de procedimentos científicos", pois trata-se de um "processo formal e sistemático de desenvolvimento do método científico".

De acordo ainda com Gil (2008) e Silva (2004), as pesquisas podem ser classificadas de acordo com diferentes critérios: quanto à abordagem do problema, quanto aos seus objetivos e quanto aos seus procedimentos.

Quanto à abordagem do problema as pesquisas podem ser caracterizadas como qualitativas e quantitativas dependendo da espécie utilizada na coleta e análise de dados. A pesquisa qualitativa é aquela cujo ambiente é identificado como fonte direta da coleta de dados e o pesquisador é visto como peça fundamental no processo (GODOY, 1995), visto que o pesquisador tenta dirimir o distanciamento existente entre a base teórica e os dados.

Já para a realização da pesquisa quantitativa é necessário que se tenha um problema muito bem definido, conhecimento do objeto que se pretende investigar, informações e teorias a respeito do objeto de estudo (SILVA; SIMON, 2005), baseados em dados estatísticos, indicando fenômenos reais e a busca por estimações ideais (GODOY, 1995). Por meio da pesquisa quantitativa busca associar a teoria e os dados observados, o que possibilitará uma classificação, mensuração e análise dos resultados obtidos (Chizzotti, 2003).

O presente estudo apresenta questões pontuais no que diz respeito aos resultados e discussões baseados em aspectos predominantemente descritivos com abordagem quantitativa, que se funda num recorte da realidade e de uma análise específica dentre as 
possíveis apresentadas no fenômeno estudado. Assim, as abordagens quantitativa e qualitativa na presente pesquisa são complementares. Para Flick (2004) a combinação entre a pesquisa quantitativa de cunho qualitativa propõe credibilidade e legitimidade aos resultados.

Quanto aos objetivos da pesquisa, entende-se que é uma pesquisa exploratória e descritiva, pois tem como finalidade apresentar um diagnóstico baseado na análise da institucionalização da gestão sustentável na Instituição observada. Pretende-se com o produto desta pesquisa auxiliar na implementação de ações e práticas socioambientais no órgão pesquisado para contribuir na disseminação das práticas sustentáveis em todas comarcas vinculadas ao Tribunal e ou outra Administração que queira implementar a gestão sustentável em seu âmbito.

Segundo Richardson (2012), os estudos exploratórios ocorrem quando não se tem informações sobre o tema, mas deseja-se conhecer o fenômeno e descritivos porque se pretende expor e dar conhecimento do fenômeno.

Corrobora Theodorson e Theodorson(1970), que o objetivo do estudo exploratório é se familiarizar com um fenômeno investigado, permitindo que o estudo proposto possa ser projetado com o maior nível de compreensão e precisão. O estudo permite ainda ao investigador determinar seu problema e estabelecer seus objetivos, possibilitando a escolha do maior número de técnicas adequadas para a pesquisa.

Explica Perovano (2014), que a pesquisa revestida de caráter descritivo, além de descrever o fenômeno permite ainda identificá-lo como um estudo de caso, que se coleta dados, onde se realiza análise entre as variáveis encontradas para traçar determinações dos efeitos resultantes.

Quanto aos procedimentos, a pesquisa pode ser caracterizada como bibliográfica e documental. Na fase inicial da pesquisa foram selecionados livros, dissertações, teses e artigos que se aproximassem da proposta desta pesquisa caracterizando a pesquisa bibliográfica.

Para auxílio na pesquisa ainda foi realizado um levantamento de dados por meio de relatórios, resoluções, recomendações, leis, que caracterizam a pesquisa documental, obtidos por meio de sites e ou diretamente com a Comissão que compõe o Núcleo de Gestão Sustentável do Tribunal. 
Esta pesquisa se caracteriza ainda, como um estudo de caso, que de acordo com Chizzotti (2014), constitui em uma busca intensiva de dados de uma situação particular, de um evento específico ou de processos contemporâneo, tomados como "caso", compreendêlo o mais amplamente possível, descrevê-lo pormenorizadamente, avaliar resultados de ações, transmitir essa compreensão a outros e instruir decisões. É, sobretudo, "um meio de organizar os dados sociais preservando o caráter unitário do objeto social estudado" (GOODE; HATT, 1979, p. 422).

Segundo Beuren (2010) o estudo de caso permite aos pesquisadores aprofundar seus conhecimentos acerca de um determinado caso específico. E de acordo com o mesmo autor, caracteriza-se como uma pesquisa descritiva, porque descreve o fenômeno em estudo, sem, contudo explicá-lo, visto que utiliza técnicas padronizadas de coleta de dados, para identificar situações, fatos, opiniões ou comportamentos.

Assim, buscou-se compreender como a gestão sustentável está sendo institucionalizada no Tribunal de Justiça do Estado do Tocantins, para dar maior conhecimento ao seu processo de institucionalização, através da identificação de normas, diretrizes e práticas desenvolvidas, para com base nos dados coletados, identificar a percepção dos servidores sobre a institucionalização da gestão socioambiental daquela instituição, para ao final recomendar melhorias ao processo, tornando público os resultados desta pesquisa que poderá servir de parâmetro para institucionalização da gestão sustentável em outros órgãos da Administração Pública.

\subsection{Coleta e Análise dos Dados}

O limite temporal compreendido para a pesquisa será entre os anos de 2014 a 2018. O marco inicial da implementação da gestão sustentável no TJTO ocorreu com a implementação da Agenda Ambiental na Administração Pública (2014), seguido da inserção do Plano de Logística Sustentável (2015), da divulgação dos resultados das metas disponibilizadas sobre o desempenho do PLS (2016 a 2017), até ser realizada a aplicação dos questionários juntos aos servidores do órgão (2018).

Com a estratégia de coleta de dados realizou-se pesquisa documental e aplicação de questionários.

Para a realização da pesquisa documental foram coletados documentos referentes aos instrumentos normativos editados pelo próprio Tribunal, o Plano de Logística 
Sustentável, os relatórios de desempenhos do PLS e os resultados obtidos com a implementação das ações, além de manuais aplicados pelo órgão.

Salientamos que a pesquisa documental teve como foco principal analisar os aspectos da gestão do Plano de Logística Sustentável do Tribunal de Justiça do Estado do Tocantins, pois se pretende efetuar o exame crítico dos dados obtidos, por meio dos elementos dos indicadores divulgados.

A análise dos elementos dos indicadores PLS/TJTO permitiu traçar um paralelo entre as estratégias lançadas com as ações operacionalizadas.

Pretendeu-se ainda, o uso de aplicação de questionários para acessar as ações e práticas implementadas com base na percepção dos servidores a respeito da institucionalização da gestão sustentável.

Os questionários foram estruturados a partir da elaboração prévia de um formulário com as perguntas a serem feitas aos servidores, que segundo Marconi e Lakatos (1999) é um instrumento que permite coleta de dados organizado em forma de uma série de perguntas, que serão submetidas e respondidas por um grupo de pessoas.

O questionário foi aplicado pessoalmente pela pesquisadora, nas datas de 10 de setembro a 28 de setembro de 2018.

Portanto, aplicou-se dois tipos de questionários com os servidores, um voltado para os membros que compõem o Núcleo de Gestão Socioambiental e membros da Comissão Gestora do Plano de Logística Sustentável e outro aplicado aos servidores que possuem cargos de chefia nas divisões ligadas às Diretorias do Tribunal. Pretendeu-se com o questionário identificar especificamente:

a) o conhecimento da temática e legislação socioambiental;

b) a relação da comissão socioambiental com a Instituição;

c) como a questão socioambiental e a sua institucionalização é tratada no órgão;

d) a sensibilização e capacitação dos servidores quanto à temática;

e) e qual a percepção sobre as práticas sustentáveis implementadas.

As aplicações dos questionários ocorreram por meio de aplicação de roteiros préestabelecidos (com 25 perguntas para questionário A e 30 perguntas para o questionário $\mathrm{B}$, conforme apêndice B e C), conforme já dito, junto aos membros do Núcleo de Gestão Socioambiental e Comissão Gestora do Plano de Logística Sustentável, por ser as duas comissões responsáveis pelas demandas socioambientais no TJTO, sendo que o núcleo é composto por três membros e a comissão por 8 membros. 
Foi aplicado ainda, questionários aos servidores com cargos de chefias vinculados às 11 Diretorias do Tribunal, ou seja, diretores e chefes de divisões do órgão. A escolha de aplicação dos questionários a esse grupo se deu em razão de que a percepção como gestor reflete na percepção dos demais servidores técnicos administrativos, haja vista que a institucionalização da gestão sustentável precipuamente depende da disseminação das ações por eles desenvolvidas e motivação para o engajamento dos seus subordinados.

Neste mister, considerando os membros do núcleo de gestão socioambiental, da comissão gestora do PLS e dos servidores que ocupam cargos de diretores e chefes de divisão era possível aplicar 60 questionários, dentre os quais 40 foram respondidos.

Do grupo que pertencem ao núcleo de gestão socioambiental, foram disponibilizados 10 questionários, haja vista que, 1 membro está constituído nas duas comissões e destes foi possível obter 8 respostas. Dos 50 questionários possíveis aos servidores com cargos de diretor e chefe de divisões 32 foram respondidos, os demais não responderam e ou não tiveram disponibilidade para receber o questionário.

O objetivo é identificar a percepção dos servidores sobre a institucionalização da gestão socioambiental no Tribunal de Justiça do Tocantins.

A identidade dos servidores foi mantida no anonimato, assim como foi apresentado um termo de consentimento livre e esclarecido (TCLE), no qual o servidor declarou sua ciência, concordando em participar da pesquisa. O roteiro do questionário foi adaptado do trabalho de Rek (2017) que fez análise semelhante no Tribunal Regional Eleitoral do Paraná.

Diante da coleta de dados, buscamos realizar uma análise geral do processo de institucionalização da gestão socioambiental, apontar as principais variáveis na relação existente entre o Plano de Logística Sustentável e a percepção dos servidores, identificando os pontos fortes e fracos na institucionalização da gestão sustentável no TJ/TO.

Os dados foram discutidos conforme a literatura revisada no referencial teórico, especialmente os atos normativos e comparação com outros estudos, quando possível.

Deste modo, metodologicamente, a pesquisa foi desenvolvida de acordo com as etapas descritas na Figura 5: 
Figura 5- Metodologia da Pesquisa

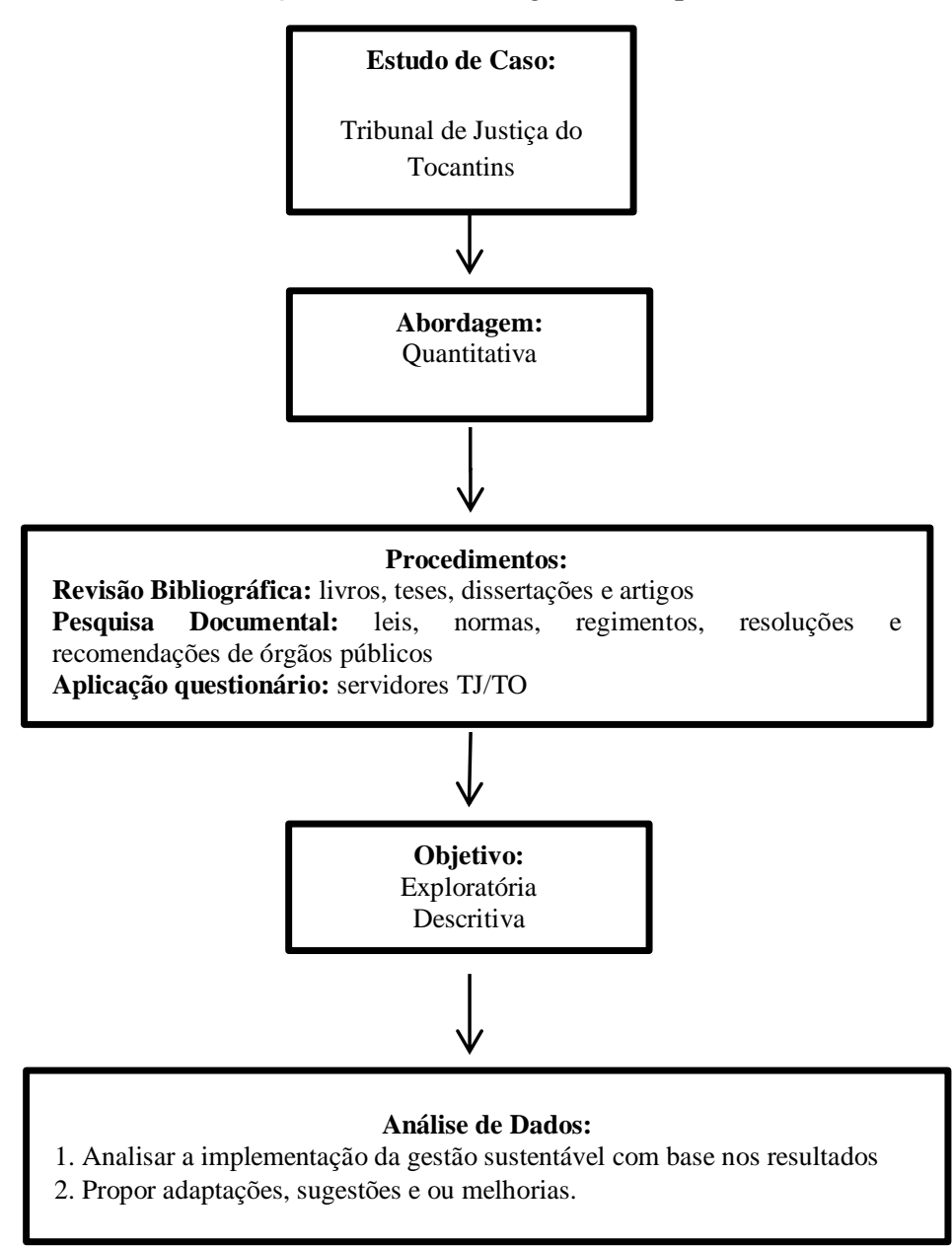

Fonte: Elaborado pela Autora

Portanto, ao final, com base na análise e dados obtidos, objetivou-se identificar os fatores ambientais que necessitam ser priorizados, cujo resultado servirá de base para indicação de pontos necessários para aprimorar o plano de gestão ambiental, podendo contribuir para a melhoria da gestão socioambiental. 


\section{ANÁLISE DOS RESULTADOS E DISCUSSÃO}

Neste capítulo será apresentado os resultados obtidos bem como sua análise e discussão a partir do arcabouço teórico exibido nos capítulos anteriores.

Assim, buscou-se primeiramente proporcionar uma visão ampla a respeito do cenário da pesquisa, contextualizando o papel do Poder Judiciário, com enfoque na Justiça Estadual, no qual os Tribunais de Justiças estão inseridos.

Realizou-se uma análise documental dos mecanismos utilizados para implementação da gestão sustentável no Tribunal de Justiça do Tocantins, por meio de dados obtidos junto ao conjunto normativo a respeito da temática, como: resoluções e recomendações do CNJ, Portarias, Plano de Logística Sustentável e Relatórios de Desempenho do PLS do Tribunal de Justiça do Tocantins, utilizado para colocar em prática os planos desenvolvidos para inserção da sustentabilidade em suas atividades administrativas.

Por fim, efetivou-se a análise da institucionalização da gestão socioambiental no referido Tribunal por meio do exame dos dados obtidos com os relatórios de desempenho do Plano de Logística Sustentável do TJTO e os questionários aplicados entre os membros da Comissão do Núcleo de Gestão Socioambiental e Comissão Gestora do Plano de Logística Sustentável e servidores que possuem cargos de chefia junto às Diretorias do Tribunal, trançando um paralelo com a análise documental já devidamente concretizada.

\subsection{Contextualização do Tribunal de Justiça do Tocantins}

Esta seção tem por objetivo contextualizar o lócus da pesquisa, por meio de uma sucinta descrição sobre a organização do Poder Judiciário a partir da verificação da legislação e doutrina sobre o assunto. Em seguida, apresenta-se as especificações e particularidades do TJ/TO.

Rege a Constituição Federal do Brasil de 1988, que "são poderes da União, independentes e harmônicos entre si, o Legislativo, o Executivo e o Judiciário" (BRASIL, 1988), do qual se faz a Administração Pública como um todo.

Na condição de Administração Pública e na função de seu papel social, compete ao Legislativo, Executivo e Judiciário à implementação de programas, projetos e ações que 
busquem disseminar atividades voltadas para a sustentabilidade nas atividades administrativas.

Nesta seara, buscou-se com a pesquisa o enfoque na participação do Poder Judiciário para a disseminação da sustentabilidade na atividade administrativa, com abordagem na atuação do Tribunal de Justiça do Estado do Tocantins, de forma a analisar o processo de institucionalização da gestão socioambiental em seu âmbito, dada a importância de se arraigar a cultura da sustentabilidade no seio social.

Deste modo, importante compreendermos como ocorre a divisão do Poder Judiciário no Brasil, para se chegar no cenário enfoque desta pesquisa.

De acordo com o artigo 92 da Constituição Federal o Poder Judiciário é composto pelos seguintes órgãos:

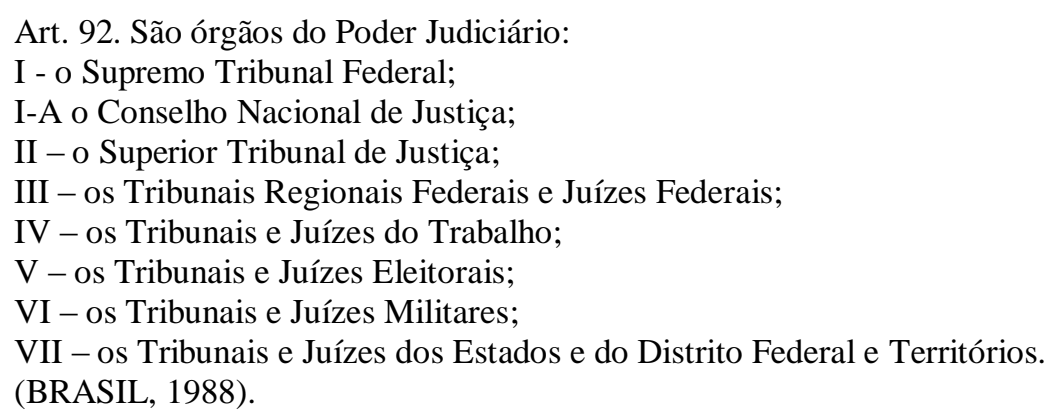

O Supremo Tribunal Federal é órgão da mais alta instância do Poder Judiciário, cuja composição da suprema corte é de 11 ministros, que desempenham funções típicas de última instância do Poder Judiciário, como a de um tribunal constitucional.

O Conselho Nacional de Justiça, muito embora não seja um Tribunal, é uma instituição vinculada ao STF que visa o controle e a transparência das atividades administrativas e processual desempenhadas pelos servidores do judiciário.

Já o Superior Tribunal de Justiça é órgão do Poder Judiciário que assegura a uniformidade nas interpretações dadas à legislação federal.

Compete aos Tribunais Regionais Federais e Juízes Federais, julgar causas em que a União, entidade autárquica ou empresa pública federal façam partes. À Justiça do Trabalho compete dirimir questões de competências trabalhistas. À Justiça Eleitoral questões pertinentes às eleições e à Justiça Militar julgar questões relacionadas a crimes militares. 
E de acordo com determinação esculpida na Carta Magna, cada Estado da Federação brasileira e o Distrito Federal possuem órgão colegiado de instância máxima no Estado, denominado de Tribunal de Justiça para o exercício da sua função precípua, que é a função jurisdicional (art. $125 \mathrm{CF}$ ), por meio do qual, segundo Lenza,“ julga dizendo o direito no caso concreto e dirime os conflitos que lhe são levados, quando da aplicação da lei” (2009, p. 339).

Considerando a composição do Poder Judiciário, buscou-se desenvolver a pesquisa no Tribunal de Justiça do Estado do Tocantins, órgão de instância máxima em âmbito estadual e que em escala de hierarquia encontra-se abaixo do Supremo Tribunal Federal e Superior Tribunal de Justiça.

A Constituição Federal de 1988, em seu art. 96 trouxe a previsão de que os Tribunais serão dotados de autonomia orgânico-administrativa, o que significa dizer que são independentes para promoverem a organização e funcionamento de seus órgãos e serviços, competindo promover as diretrizes que melhor aprouver para o andamento das funções de sua competência, o que permitem o exercício das funções atípicas a eles inerentes, administrar e legislar.

Nesta seara, imbuídos das funções administrativas e legislativa, que o Tribunal de Justiça do Estado do Tocantins usufruindo de sua autonomia, desenvolveu instrumentos para atender as imposições do Conselho Nacional de Justiça e implementar a prática da sustentabilidade em seu âmbito.

O Tribunal de Justiça do Estado do Tocantins é o mais novo Tribunal de Justiça do país, visto que foi criado juntamente com o Estado do Tocantins em 1988, cuja instalação precípua se deu em 1989 de forma improvisada na cidade de Miracema, capital provisória do Estado à época, mudando-se definitivamente para a Capital Palmas em 1990, quando esta passou a ser a capital do Estado (TJTO, 2015).

A Corte do Tribunal é composta por 12 Desembargadores, que se subdividem entre 02 Câmaras Cíveis e 02 Câmaras Criminais, com a composição de 04 Turmas para cada Câmara. Atualmente o quadro de pessoal do Tribunal é composto por 2544 servidores, dentre magistrados, efetivos, comissionados e estagiários. Sobre sua jurisdição estão 42 comarcas distribuídas entre os municípios do Estado.

O Tribunal de Justiça do Tocantins tem como missão a garantia da cidadania através da distribuição de uma justiça célere, justa e eficaz (TJTO, 2015). 
A visão institucional do Tribunal é ser reconhecido como o mais moderno, célere e eficaz dos Tribunais do país e para tanto busca cultivar os valores da eficiência, ética, credibilidade, presteza, inovação e cooperação, responsabilidade social, transparência, comprometimento e sustentabilidade, buscando implementar políticas de gestão que visem atenuar as desigualdades sociais e garantir os direitos das minorias, observando-se, para tanto, práticas socioambientais sustentáveis e de uso de tecnologia limpa (TJTO, 2015).

Neste mister, é de competência do Tribunal de Justiça do Tocantins a instituição de normas para o cumprimento das diretrizes apresentadas pelo CNJ aos órgãos do Poder Judiciário para a contribuição social referente as questões ambientais, cujas normativas e ações serão apresentadas nas subseções seguintes.

4.1.1 Descrição dos instrumentos normativos do Tribunal de Justiça do Tocantins

4.1.1.1 Resolução nº. 22/2015 - Institui Núcleo de Gestão Socioambiental do Poder Judiciário do Estado do Tocantins

Conforme já visto, o CNJ através de suas recomendações e resoluções impôs a necessidade de instituição de comissões ambientais no âmbito dos Tribunais para o planejamento, implementação e monitoramento das práticas socioambientais.

Deste modo, em 2015 foi instituído o Núcleo de Gestão Socioambiental do Poder Judiciário do Estado do Tocantins, por meio da Resolução nº 22.

O referido núcleo possui caráter permanente e encontra-se vinculado à Diretoria Geral do Tribunal, competindo a estes o planejamento, implementação, monitoramento das metas estabelecidas e avaliação de desempenho quanto ao cumprimento das imposições contidas na Resolução nº. 201 do CNJ (TJTO, 2015).

O núcleo deverá ser composto, no mínimo, por 1 coordenador e 2 servidores, devendo estes serem servidores efetivos, cuja dedicação deverá ser exclusiva às atividades do núcleo.

Dentre as suas atribuições está a de elaborar, monitorar, avaliar e revisar com a comissão gestora, o Plano de Logística Sustentável do TJTO, proporcionar meios para o gasto público com qualidade e o uso sustentável dos bens públicos, promover a gestão adequada de resíduos, definir projetos, programas e ações voltadas para a sustentabilidade, sensibilizar todo corpo técnico do Tribunal quanto ao conhecimento e práticas ambientais, 
sugerir mudanças que levem ao tripé básico da sustentabilidade, monitorar e avaliar projetos a serem implementados e àqueles em desenvolvimento (TJTO).

Denota-se por meio das atribuições inerentes ao Núcleo de Gestão Socioambiental a importância deste para o desenvolvimento de práticas ambientais no Tribunal, demonstrando que o órgão está engajado ou pelo menos atento as imposições necessárias para o cumprimentos das metas do $\mathrm{CNJ}$, no que diz respeito à temática.

4.1.1.2 Portaria no. 3943/2015 - Institui Comissão Gestora do Plano de Logística Sustentável do Poder Judiciário do Estado do Tocantins

Considerando o Planejamento Estratégico adotado pelo TJTO 2015-2020, que contempla o projeto A3P; a Resolução $\mathrm{n}^{\circ}$. 201 do CNJ que impõe a necessidade de implantação de Plano de Logística Sustentável em todos os órgãos do Poder Judiciário; a Resolução no. 22/2015 do TJTO que instituiu o Núcleo de Gestão Socioambiental em seu âmbito; e a responsabilidade ambiental assumida pelo Tribunal no PPA do órgão, o Tribunal de Justiça do Tocantins instituiu a Comissão Gestora para implantação do Plano de Logística Sustentável (TJTO, 2015).

A instituição da Comissão se deu por meio da Portaria nº 394318 de setembro de 2015.

A comissão é composta por 8 membros, sendo que um deles é o Coordenador do Núcleo de Gestão Socioambiental, que na ausência do Presidente da comissão, possui o dever de substituí-lo.

É atribuição da comissão elaborar, avaliar e revisar o PLS do órgão, juntamente com o Núcleo de Gestão Socioambiental, compor o PLS com dados dos indicadores e os planos para alcançar as metas estabelecidas, definir o cronograma de trabalho anualmente, subsidiar informações com base nas ações desenvolvidas para publicação de seus resultados e elaborar os relatório de desempenho do PLS TJTO (TJTO, 2015).

O Núcleo de Gestão Socioambiental e a Comissão Gestora do Plano de Logística Sustentável, juntas, formam a comissão ambiental do TJTO, sendo que suas ações estão inter-relacionadas e interligadas, uma dependendo da outra para desenvolver as práticas necessárias à implementação da sustentabilidade no órgão.

Após a instituição da comissão gestora, o Plano de Logística Sustentável foi elaborado e apresentado conforme descrito na subseção seguinte. 


\title{
4.2. Análise do Plano de Logística Sustentável e Relatórios de Desempenhos
}

Conforme visto no tópico anterior visando dar cumprimento à Resolução no .201 do CNJ, o Tribunal de Justiça do Estado do Tocantins após implantar o Núcleo de Gestão Socioambiental, tão logo, tomou providências para nomear a Comissão Gestora para elaboração do Plano de Logística Sustentável.

O Plano de Logística Sustentável:

\begin{abstract}
é o instrumento capaz de promover a transição da fase retórica para a de adoção de ações de boas práticas sustentáveis, pois procura concentrar esforços em conceber um instrumento de gestão norteado tanto pelos princípios da sustentabilidade quanto pelos da lisura e transparência, com pilares para construção de uma política ambiental institucional permanente.” (PLS, 2016, p. 6)
\end{abstract}

Trata-se, portanto, de um processo ordenado por meio do qual se realiza o diagnóstico, monitoramento das atividades, para posteriormente implantar melhorias na gestão dos trabalhos com vistas à adoção de métodos sustentáveis que permitem ao órgão:

a) adotar modelo de gestão que possibilitem a promoção da sustentabilidade ambiental, econômica e social;

b) levantar por meio de indicadores o consumo e os gastos e o seu monitoramento;

c) estimular a necessidade de mudança com relações aos padrões adotados para compras, consumo, qualidade de vida no trabalho, sensibilização dos servidores e formas auxiliares (TJTO, 2015).

De acordo com a Portaria $n^{\circ}$. 3943/2015, para a ocorrência da racionalização e consumo consciente de materiais e serviços, o Plano de Logística sustentável deve contemplar no mínimo o uso eficiente de materiais, energia elétrica, água e esgoto, gestão de resíduos, qualidade de vida no ambiente do trabalho, sensibilização e capacitação contínua do corpo funcional, contratações sustentáveis e deslocamento de pessoal com foco na redução de gastos de emissões de substância poluentes.

Assim, o PLS TJTO tem como objetivo precípuo instituir mecanismos de controle e monitoramento de ações socioambientais como forma de auxiliar na implementação da sustentabilidade social, ambiental e econômica, pretendendo-se para tanto, desenvolver mecanismos para efetivação da sustentabilidade, redução de custos nos processos administrativos e judiciais, promover licitações sustentáveis, estruturar os serviços de edificações, eliminar desperdícios, adotar adequadamente a gestão, redução e destinação 
apropriada de resíduos, promover educação ambiental e melhor qualidade de vida (PLS, 2016).

É cediço que para as transformações pretendidas a adoção de medidas e princípios sustentáveis demanda mudança de atitudes e aplicação de métodos a serem observados por todos, para se alcançar os objetivos traçados pelo TJTO, em seu Planejamento Estratégico 2015-2020, que é transformar o Poder Judiciário do Tocantins em referencial de sustentabilidade e responsabilidade social.

A metodologia utilizada para avaliação do PLS, foi a mesma adotada pelo CNJ, fundamentada no Sistema Balance Scorecard (BSC), constituindo-se no ciclo PDCA, planejar, executar, verificar e revisar, sendo sua estruturação baseada na Cartilha A3P.

Conforme disposto no documento do Plano de Logística Sustentável (2015) para a sua elaboração foi levado em consideração 9 etapas:

1 - Preparação - constituição da Comissão Gestora do Plano;

2 - Diagnóstico - realizado intersetorialmente por meio dos gestores administrativos, elaborando planilhas para recolhimento das informações, referentes ao ano de 2015, produzindo-se relatório consolidado do inventário de bens e materiais do órgão;

3 - Elaboração do Plano - criação de plano de ações com objetivos, atos, metas e responsabilidades definidas, prazos e recursos humanos e financeiros;

4 - Alinhamento Estratégico - conforme macrodesafio do planejamento estratégico determinado pela Resolução CNJ nº. 201/2015;

5 - Implementação do Plano - cuja competência é dos gestores da unidades relacionadas nos planos de ação;

6 - Monitoramento - competência da própria Comissão que será responsável pelo monitoramento dos indicadores;

7 - Avaliação - será realizada anualmente pela Comissão Gestora do PLS/TO e pelo Núcleo de Gestão Socioambiental, com base nos indicadores;

8 - Revisão do Plano - Será revisto pela Comissão Gestora e pelo Núcleo de Gestão Socioambiental anualmente no mês de outubro;

9 - Delimitação dos Indicadores de Racionalidade e Sustentabilidade.

O Plano de Logística Sustentável do Tribunal de Justiça do Tocantins é circunspeto por 15 eixos temáticos com responsabilidades distribuídas entre as Diretorias que compõem o Tribunal de Justiça do Tocantins, conforme apresentado na Quadro 2: 
Quadro 2 - Matriz de Responsabilidades

\begin{tabular}{|c|c|}
\hline EIXO TEMÁTICO & $\begin{array}{c}\text { DIRETORIA } \\
\text { RESPONSÁVEL }\end{array}$ \\
\hline Gestão de materiais de consumo - Papel & DIADM \\
\hline Gestão de materiais de consumo - Agua Engarrafada & DIADM \\
\hline Gestão de consumo e gasto com Água e Esgoto & DIADM \\
\hline Gestão de materiais de consumo - Copos descartáveis & DIADM \\
\hline Gestão de consumo e gastos com Energia Elétrica & DIADM \\
\hline Gestão de Resíduos & DIADM/DINFRA/DTINF \\
\hline Gestão dos serviços de Limpeza & DIADM \\
\hline Gestão dos serviços de Vigilância & ASMIL \\
\hline Gestão do consumo de Combustível & DIADM \\
\hline Gestão da frota de Veículos & DIADM \\
\hline Gestão de Layout & DINFRA \\
\hline Gestão da Educação Socioambiental & ESMAT \\
\hline Gestão de gastos com serviços de Telefonia e Transmissão de Dados & DTINF \\
\hline Gestão de Impressão de documentos e equipamentos instalados & DTINF \\
\hline Gestão da Qualidade de Vida no Ambiente de Trabalho & DIGEP \\
\hline
\end{tabular}

Fonte: Plano de Logística Sustentável Tribunal de Justiça do Tocantins (2016)

De acordo com o PLS de 2016, cada eixo temático possui indicadores de racionalidade e sustentabilidade para avaliação do desempenho ambiental e econômico, possibilitando aos gestores analisar a operacionalidade da política ambiental e redirecionar, as ações em busca de metas e resultados (PLS, 2016).

É por meio dos relatórios que se torna possível a avaliação da evolução das práticas adotadas no órgão, analisar as metas e os desempenhos alcançados para cada eixo temático implantado, permitindo aferir se a implantação do programa está sendo eficiente e os reflexos destes está prevalecendo no cotidiano da atividade administrativa da Instituição.

O Conselho Nacional de Justiça orienta que os Tribunais divulguem anualmente no mês de outubro, no site do próprio Tribunal, relatórios que possam aferir metas e objetivos traçados para os planos de ação de cada eixo temático indicados no PLS. Deste modo, o Tribunal de Justiça do Tocantins, por meio da Comissão Gestora do Plano de Logística Sustentável, apresentou em outubro de 2016 e 2017 por meio dos relatórios os resultados e desempenho do PLS do TJTO.

Com base nos relatórios divulgados nos é possível realizar uma comparação entre as práticas ocorridas de acordo com cada eixo temático. Assim a metodologia adotada para a referida análise será a descrição do eixo temático e ou subtema, apresentação do objetivo, exposição das metas para cada ano, seguida do seu desempenho:

\section{Gestão de Materiais de Consumo:}


a) Subtema Papel: Aferição do consumo individualizado da quantidade de resmas de papel branco e reciclado e o valor gasto, assim como a quantidade total de resmas de papel branco e reciclado, com apuração no mês e no ano (PLS, 2016).

Objetivo: Promover o uso racional dos recursos naturais e bens públicos (PLS, 2016).

Quadro 3 - Resultado Gestão Materiais Consumo Papel

\begin{tabular}{|l|l|l|}
\hline 2016 & Meta & Desempenho \\
\hline 2017 & $\begin{array}{l}\text { Reduzir em 10\% os } \\
\text { gastos com aquisição } \\
\text { de papel }\end{array}$ & $\begin{array}{l}\text { Superação das metas em razão da } \\
\text { sensibilização dos servidores e } \\
\text { investimentos no monitoramento de } \\
\text { impressão }\end{array}$ \\
\hline $\begin{array}{l}\text { Não foi estabelecida } \\
\text { Meta }\end{array}$ & Prejudicada \\
\hline
\end{tabular}

Fonte: Elaboração Própria com base no Relatório de Desempenho do PGLS do TJTO Ano-Base 2016 e 2017

Veja que a meta estabelecida para o ano de 2016 foi superada, visto o trabalho de sensibilização realizado junto ao corpo funcional e a adoção de compras de equipamentos que permitem o controle das impressões. Foi possível observar em visita ao órgão para realização desta pesquisa, que foram adotadas ilhas de impressões instaladas nos corredores que conectam as salas das divisões de trabalho, o que permitem a redução de impressões e consequentemente o uso de papel.

b) Subtema Copos Descartáveis: Consumo de copos de 200 e $80 \mathrm{ml}$ em quantidade (centos) de copos total para o corpo funcional mais força de trabalho auxiliar utilizado e o valor gasto no semestre e no ano (PLS, 2016).

Objetivo: Promover o uso racional dos recursos naturais e bens públicos; redução de resíduos sólidos e de impactos negativos no meio ambiente, bem como prover a qualidade de vida no ambiente de trabalho (PLS, 2016).

Quadro 4 - Resultado Gestão Materiais Consumo Copos Descartáveis

\begin{tabular}{|l|l|l|}
\hline & Meta & Desempenho \\
\hline 2016 & $\begin{array}{l}\text { Alcançar } 100 \% \text { os servidores } \\
\text { com ações de sensibilização }\end{array}$ & Meta cumprida \\
\hline 2017 & $\begin{array}{l}\text { Atender em } 100 \% \text { a unidades } \\
\text { e Reduzir em } 2 \% \text { o consumo }\end{array}$ & Meta Cumprida \\
\hline
\end{tabular}

Fonte: Elaboração Própria com base no Relatório de Desempenho do PGLS do TJTO Ano-Base 2016 e 2017 
As metas estabelecidas tanto para o ano de 2016 quanto para o ano de 2017, foram cumpridas. É noticiado que o TJTO adotou a iniciativa da confecção de canecas de fibras de coco que foram distribuídos para os servidores (TJTO 2016), o que demonstra ações voltadas para a sensibilização do corpo funcional e a consequente redução do material.

c) Subtema Água Engarrafada: Consumo de água envasada em embalagens plásticas (com e sem gás) explicando o volume utilizado em quantidade de garrafas descartáveis consumidas e consumo de garrafões de água de 20 litros, além dos gastos na aquisição de ambos no semestre e no ano (PLS, 2016).

Objetivo: Promover o uso racional dos recursos naturais e bens públicos e redução de resíduos sólidos (PLS, 2016).

Quadro 5 - Resultado Gestão Materiais Consumo Água Engarrafada

\begin{tabular}{|l|l|l|}
\hline & Meta & Desempenho \\
\hline 2016 & $\begin{array}{l}\text { Alcançar 100\% os servidores } \\
\text { comações de sensibilização e } \\
\text { monitorar em 100\% as } \\
\text { unidades }\end{array}$ & Meta cumprida \\
\hline 2017 & $\begin{array}{l}\text { Alcançar 100\% os servidores } \\
\text { com sensibilização e } \\
\text { monitorar os dados de } \\
\text { consumo cumprida }\end{array}$ & \\
\hline
\end{tabular}

Fonte: Elaboração Própria com base no Relatório de Desempenho do PGLS do TJTO Ano-Base 2016 e 2017

Além da sensibilização ocorrida a respeito do eixo temático, foi constatado em visita junto ao órgão para realização da pesquisa e por meio de relatos do Diretor de Obras e Infraestrutura que foi adotado o sistema de instalação de filtros nos corredores que interligam as salas de cada departamento, permitindo a redução no consumo do material.

2. Gestão de Impressão de Documentos e Equipamentos Instalados: visa-se o levantamento do quantitativo de impressões de documentos do corpo de trabalho funcional e quantidade de equipamentos instalados por unidade de trabalho semestral e anual; performance dos equipamentos instalados baseado na quantidade de equipamentos por unidade de trabalho no semestre; gastos na aquisição de suprimentos, impressoras e com contratos de outsourcing no ano (PLS, 2016).

Objetivo: Promover o uso racional de recursos naturais e bens públicos, redução de resíduos e emissão de $\mathrm{CO}^{2}$ na atmosfera (PLS, 2016). 
Quadro 6 - Gestão de Impressão de Documentos e Equipamentos Instalados

\begin{tabular}{|c|c|c|}
\hline & Meta & Desempenho \\
\hline 2016 & $\begin{array}{l}\text { Não foi estabelecida meta de } \\
\text { redução }\end{array}$ & $\begin{array}{l}\text { Não há controle eletrônico de } \\
\text { impressão em todas as } \\
\text { unidades }\end{array}$ \\
\hline 2017 & $\begin{array}{l}\text { Coleta Seletiva de } 100 \% \text { dos } \\
\text { resíduos de informática } \\
\text { gerado, realizar estudo de } \\
\text { viabilidade para uso da } \\
\text { ferramenta gerencial de } \\
\text { impressão PaperCut, Inserção } \\
\text { de } 100 \% \text { no contratos novos } \\
\text { da Logística Reversa, além de } \\
\text { revisão dos contratos em } \\
\text { vigência, Inserir } 100 \% \text { nos } \\
\text { contratos nas compras e } \\
\text { contratações sustentáveis, } \\
\text { controlar e monitorar uso da } \\
\text { impressão outsourcing além } \\
\text { de revisar os contratos. }\end{array}$ & Metas cumpridas \\
\hline
\end{tabular}

Fonte: Elaboração Própria com base no Relatório de Desempenho do PGLS do TJTO Ano-Base 2016 e 2017

Vislumbra-se que para o ano de 2016 não foi proposta meta quanto à redução na quantidade de impressões. Muito embora não se tenha estabelecido meta é cediço que os processos que tramitam no TJTO seja judicial e ou administrativo é $100 \%$ eletrônico o que pode ser apontado como um fato preponderante para a redução pretendida.

Sendo que para o ano de 2017, foi estabelecida a meta para coleta seletiva, logística reversa e monitoramento das impressões, o que foi devidamente cumprida.

3. Gestão do Consumo e Gasto com Energia Elétrica: Aferição do consumo de energia elétrica consumida e por área construída por Kwh com apuração do valor da fatura por mês e por ano, além da adequação do contrato de demanda (fora de ponta) em porcentagem no mês (PLS, 2016).

Objetivo: Promover o uso racional dos recursos público e ambiental (PLS, 2016).

Quadro 7 - Gestão do Consumo e Gasto com Energia Elétrica

\begin{tabular}{|l|l|l|}
\hline & Meta & Desempenho \\
\hline 2016 & $\begin{array}{l}\text { Não foi estabelecida meta de } \\
\text { redução }\end{array}$ & $\begin{array}{l}\text { Houve redução no consumo } \\
\text { com sensibilização dos } \\
\text { servidores, compra de } \\
\text { aparelhos eletrônicos mais } \\
\text { econômicos, mas com } \\
\text { elevação de gastos em razão } \\
\text { do aumento das tarifas. }\end{array}$ \\
\hline 2017 & $\begin{array}{l}\text { Realizar diagnóstico das } \\
\text { instalações em 5\% das } \\
\text { unidades, propor alterações }\end{array}$ & $\begin{array}{l}\text { A meta do diagnóstico foi } \\
\text { cumprida, a inclusão de } \\
\text { sustentabilidade }\end{array}$ \\
\hline
\end{tabular}




\begin{tabular}{|l|l|l|}
\hline & $\begin{array}{l}\text { para redução do consumo e } \\
\text { compras parcialmente cumprida. } \\
\text { incluindo custentáveis } \\
\text { sustentabilidade em } 100 \% \text { dos } \\
\text { novos contratos }\end{array}$ & \\
\hline
\end{tabular}

Fonte: Elaboração Própria com base no Relatório de Desempenho do PGLS do TJTO Ano-Base 2016 e 2017

O relatório aponta que no ano de 2016 não foi estabelecida nenhuma meta de redução no consumo de energia elétrica, contudo, afirma que houve sensibilização junto ao corpo funcional e aquisição de aparelhos econômicos, mas em razão do aumento da tarifa de energia restou constatado um aumento nos gastos no referido ano.

A meta estabelecida para 2017 foi alcançada.

Em visita ao Tribunal para realização da pesquisa foi relatado por diversos diretores que um possível fator que não contribui com a redução de gastos com a energia elétrica é o descuido por parte dos servidores que deixam luzes, computadores e até condicionadores de ar ligados ao irem embora.

4. Gestão do Consumo e Gasto com Água e Esgoto: Volume de água consumida e por área construída em quantidade de $\mathrm{m}^{3}$ e os respectivos gastos mensal e anual (PLS, 2016).

Objetivo: Promover o uso racional dos recursos público e ambiental (PLS, 2016).

Quadro 8 - Gestão do Consumo e Gasto com Água e Esgoto

\begin{tabular}{|l|l|l|}
\hline 2016 & Meta & Desempenho \\
\hline 2017 & $\begin{array}{l}\text { Não foi estipulada meta } \\
\text { quantitativa }\end{array}$ & $\begin{array}{l}\text { Sem meta não houve } \\
\text { avaliação de desempenho }\end{array}$ \\
\hline & $\begin{array}{l}\text { Monitorar 100\% os gastos } \\
\text { das unidades, informar dados } \\
\text { de consumo e promover a } \\
\text { sensibilização dos usuários }\end{array}$ & \multicolumn{1}{|c|}{ Meta Cumprida } \\
\hline
\end{tabular}

Fonte: Elaboração Própria com base no Relatório de Desempenho do PGLS do TJTO Ano-Base 2016 e 2017

Não foi possível realizar uma avaliação para o ano de 2016, tendo em vista que não foi estipulada meta.

A meta estabelecia para o ano de 2017 foi devidamente cumprida.

Em visita ao órgão para realização da pesquisa foi possível colher em conversa com o Diretor da Diretoria de Obras e Infraestrutura que o sistema de utilização de água nos vasos sanitários foram modificados, assim como o das torneiras que funcionam por meio de sensor, contribuindo assim, para a diminuição dos gastos com utilização de água. 
5. Gestão de Resíduos: Destinação de papel, de suprimentos de impressão, plástico, vidros, metais, resíduos de obras, resíduos de informática para reciclagem, destinação de lâmpadas, pilhas e baterias, resíduos de saúde para descontaminação, destinação de madeiras para reaproveitamento, com apuração em quilos e ou unidades em quantidade total no mês e no ano (PLS, 2016).

Objetivo: Fomentar a responsabilidade social e ambiental e a destinação ecologicamente correta dos resíduos gerados (PLS, 2016).

Quadro 9 - Gestão de Resíduos

\begin{tabular}{|c|c|c|}
\hline & Meta & Desempenho \\
\hline 2016 & $\begin{array}{l}\text { Implantar até } 2020 \text { o } \\
\text { Programa de Coleta Seletiva } \\
\text { nas unidades. Não sendo } \\
\text { estipulado meta quantitativa }\end{array}$ & Prejudicado \\
\hline 2017 & $\begin{array}{l}\text { Revisar em } 100 \% \text { os contratos } \\
\text { de aquisição de material } \\
\text { Promover mudanças no } \\
\text { aproveitamento dos gastos } \\
\text { públicos, adquirir produtos de } \\
\text { selo de qualidade de } \\
\text { sustentabilidade ambiental, } \\
\begin{array}{l}\text { consumo consciente, } \\
\text { conscientização } \\
\text { servidores }\end{array}\end{array}$ & $\begin{array}{l}\text { Não foi possível aferir o grau } \\
\text { de execução das ações nem o } \\
\text { percentual de cumprimento } \\
\text { das metas, em razão da } \\
\text { Diretoria não prestar as } \\
\text { informações solicitadas. }\end{array}$ \\
\hline
\end{tabular}

Fonte: Elaboração Própria com base no Relatório de Desempenho do PGLS do TJTO Ano-Base 2016 e 2017

Só será possível avaliar se a meta estipulada para 2016 será cumprida com o fim do prazo estipulado para implantação da coleta seletiva, razão pela qual esta avaliação restou prejudicada. Assim como restou prejudicada a análise para a meta estabelecida para o ano de 2017, visto que a diretoria responsável deixou de repassar as informações prejudicando a análise.

6. Gestão de Qualidade de vida no Ambiente de Trabalho: Participação dos servidores e ou ações voltadas para qualidade de vida no trabalho, ações solidárias em quantidade x 100 e de inclusão de servidores com deficiência em quantidade com aferição anual (PLS, 2016).

Objetivo: Promover a qualidade de vida no ambiente de trabalho (PLS, 2016).

Quadro 10 - Gestão de Qualidade de Vida no Ambiente de Trabalho

\begin{tabular}{|l|l|l|}
\hline & Meta & Desempenho \\
\hline 2016 & $\begin{array}{l}\text { Realização de cinco ações de } \\
\text { qualidade de vida }\end{array}$ & Meta superada \\
\hline
\end{tabular}




\begin{tabular}{|l|l|l|}
2017 & $\begin{array}{l}\text { Desenvolvimento de 15 ações } \\
\text { de qualidade de vida }\end{array}$ & $\begin{array}{l}\text { Das ações algumas foram } \\
\text { atingidas, outras não e outras } \\
\text { parcialmente }\end{array}$ \\
\hline
\end{tabular}

Fonte: Elaboração Própria com base no Relatório de Desempenho do PGLS do TJTO Ano-Base 2016 e 2017

As metas estabelecidas para o ano de 2016 no total de 5 ações foi superada. Aumentado o número de ações de 5 para 15 no ano de 2017, nem todas foram alcançadas com sucesso. Em visita ao Tribunal e com base em divulgações realizadas no próprio site do TJTO é possível observar que este eixo é um dos mais divulgados com muitas ações voltadas para a sua consecução e conforme diagnóstico apresentado pelo próprio relatório algumas ações são cumpridas na sua integralidade e outras não.

7. Gestão de Gastos com Serviços de Telefonia: Gasto médio e total do contrato de telefonia fixa e móvel, com descrição do valor da fatura quantidade de linhas mensal e anual (PLS, 2016).

Objetivo: Uso racional dos recursos naturais e bens públicos, redução de resíduos e emissão de $\mathrm{CO}^{2}$ na atmosfera, melhoria do ambiente de trabalho (PLS, 2016).

Quadro 11 - Gestão de Gastos com Serviços de Telefonia

\begin{tabular}{|c|c|c|}
\hline & Meta & Desempenho \\
\hline 2016 & $\begin{array}{l}\text { Não foi estabelecida meta com } \\
\text { redução }\end{array}$ & Prejudicado \\
\hline 2017 & $\begin{array}{l}\text { Utilização de } \\
\text { gratuitos } 100 \% \text {, implantação } \\
\text { de serviços } \\
\text { videoconferência, compras e } \\
\text { contratações } \\
\text { 100\%, adoção da logística } \\
\text { reversa nos contratos, } \\
\text { monitorar o uso dos serviços } \\
\text { de telefonia 100\%, revisar } \\
\text { contratos de telefonia fixa } \\
100 \% \text { com redução de custos } \\
\text { em 2\%, móvel e de } \\
\text { transmissão de dados e } \\
\text { instalar Call Center }\end{array}$ & $\begin{array}{l}\text { Utilização de serviços } \\
\text { gratuitos, compras e } \\
\text { contratações sustentáveis, } \\
\text { adoção de logística reversa } \\
\text { nos contratos, controle e } \\
\text { monitoramento dos serviços e } \\
\text { revisão dos contratos, Meta } \\
\text { Cumprida. } \\
\begin{array}{l}\text { As demais não foram } \\
\text { atingidas }\end{array}\end{array}$ \\
\hline
\end{tabular}

Fonte: Elaboração Própria com base no Relatório de Desempenho do PGLS do TJTO Ano-Base 2016 e 2017

Não foram estabelecidas metas para o ano de 2016, restando, portanto, prejudicada a avaliação. Sendo que as metas estabelecidas para o ano de 2017 teve o cumprimento de forma parcial.

Em visita ao Tribunal para execução da pesquisa, o sistema Voip foi bastante mencionado pelos servidores como forma eficaz de comunicação interna e externa com 
todas as comarcas do Estado, além do sistema que permite trocas de mensagens instantâneas, contribuindo com a redução dos gastos com o uso de telefonia.

8. Gestão dos Serviços de Vigilância: Valor inicial e atual do posto de vigilância descrevendo a respeito do valor total anual do contrato por quantidade de postos e de repactuação (PLS, 2016).

Objetivo: Promover o aperfeiçoamento da qualidade de gasto público e a qualidade de vida no ambiente de trabalho (PLS, 2016).

Quadro 12 - Gestão dos Serviços de Vigilância

\begin{tabular}{|c|c|c|}
\hline & Meta & Desempenho \\
\hline 2016 & $\begin{array}{l}\text { Revisar } 100 \% \text { os contratos, } \\
\text { sem estabelecer meta de } \\
\text { redução ou aumento }\end{array}$ & Meta Cumprida \\
\hline 2017 & 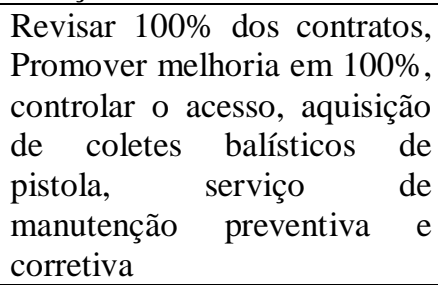 & $\begin{array}{l}\text { Os contratos, aquisição de } \\
\text { coletes, pistolas foram } \\
\text { cumpridas, a melhoria na } \\
\text { segurança e serviços de } \\
\text { manutenção foi cumprida } \\
\text { parcialmente }\end{array}$ \\
\hline
\end{tabular}

Fonte: Elaboração Própria com base no Relatório de Desempenho do PGLS do TJTO Ano-Base 2016 e 2017

As metas estabelecidas para ao ano de 2016 foram cumpridas, sendo que as de 2017 tiveram o cumprimento de forma parcial.

9. Gestão de Serviços de Limpeza: Gastos com limpeza por área construída, grau de repactuação e gastos com materiais de limpeza, valor total anual de cada indicador individualmente (PLS, 2016).

Objetivo: Uso racional dos recursos ambientais e públicos e redução de resíduos (PLS, 2016).

Quadro 13 - Gestão de Serviços de Limpeza

\begin{tabular}{|l|l|l|}
\hline & Meta & Desempenho \\
\hline 2016 & $\begin{array}{l}\text { Não foram estipuladas metas } \\
\text { de redução }\end{array}$ & Prejudicado \\
\hline 2017 & $\begin{array}{l}\text { Reduzir em 100\% os gastos } \\
\text { com café e promover a } \\
\text { compra sustentável }\end{array}$ & Meta não alcançada \\
\hline
\end{tabular}

Fonte: Elaboração Própria com base no Relatório de Desempenho do PGLS do TJTO Ano-Base 2016 e 2017 
Não foram estipuladas metas para o ano de 2016, restando a avaliação prejudicada. Sendo que a meta estabelecida para o ano de 2017, redução com os gatos gerados com café e promoção da compra sustentável não teve a meta alcançada.

10. Gestão do Consumo de Combustível: Consumo de gasolina, etanol e diesel da frota oficial de veículos, quantidade de litros de gasolina e km rodados mensal e anual (PLS, 2016).

Objetivo: Promover o uso racional dos recursos e bens públicos, contribuir para a redução de emissão $\mathrm{CO}^{2}$ na atmosfera e reduzir o consumo de combustível (PLS, 2016).

Quadro 14 - Gestão do Consumo de Combustível

\begin{tabular}{|l|l|l|}
\hline 2016 & Meta & Desempenho \\
\hline 2017 & Reduzir em 10\% os gastos & $\begin{array}{l}\text { A meta não foi alcançada em } \\
\text { razão da demanda }\end{array}$ \\
\hline & $\begin{array}{l}\text { Reduzir em 10\% o consumo } \\
\text { de combustível e implantar } \\
\text { sistema eletrônico de gestão } \\
\text { de frota }\end{array}$ & $\begin{array}{l}\text { Não atingindo a meta de } \\
\text { redução do consumo, contudo } \\
\text { implantando o sistema }\end{array}$ \\
\hline
\end{tabular}

Fonte: Elaboração Própria com base no Relatório de Desempenho do PGLS do TJTO Ano-Base 2016 e 2017

As metas estabelecidas tanto para o ano de 2016 quanto para o ano de 2017 não foram alcançadas, sob a justificativa do aumento na demanda e não utilização do sistema já implantado.

11. Gestão da Frota de Veículos: Veículos para transporte de servidores, magistrados e gastos com manutenção dos veículos da frota, quantidade de veículos utilizados no transporte e valor da fatura do total de contratos de manutenção por ano (PLS, 2016).

Objetivo: Promover o uso racional dos recursos e bens públicos, contribuir para a redução de emissão $\mathrm{CO}^{2}$ na atmosfera e reduzir o consumo de combustível (PLS, 2016).

Quadro 15 - Gestão da Frota de Veículos

\begin{tabular}{|l|l|l|}
\hline 2016 & Meta & Desempenho \\
\hline 2017 & $\begin{array}{l}\text { Reduzir em 10\% os gastos } \\
\text { com combustível }\end{array}$ & $\begin{array}{l}\text { A meta não foi alcançada em } \\
\text { razão da demanda }\end{array}$ \\
\hline $\begin{array}{l}\text { Reduzir em 10\% o consumo } \\
\text { de combustível e implantar } \\
\text { sistema eletrônico de gestão } \\
\text { de frota }\end{array}$ & $\begin{array}{l}\text { Não atingindo a meta de } \\
\text { redução do consumo, contudo } \\
\text { implantando o sistema }\end{array}$ \\
\hline
\end{tabular}

Fonte: Elaboração Própria com base no Relatório de Desempenho do PGLS do TJTO Ano-Base 2016 e 2017 
As metas estabelecidas tanto para o ano de 2016 quanto para o ano de 2017 não foram alcançadas, sob a justificativa do aumento na demanda e não utilização do sistema já implantado.

12. Gestão de Layout: valor gasto com reformas nas unidades no ano vigente e no ano anterior, com apuração anual (PLS, 2016).

Objetivo: Promover a redução do consumo de água, fomentar o desenvolvimento econômico local, gerenciar adequadamente os resíduos de obras e adotar prática de licitações sustentáveis (PLS, 2016).

Quadro 16 - Gestão de Layout

\begin{tabular}{|l|l|l|}
\hline & Meta & Desempenho \\
\hline 2016 & $\begin{array}{l}\text { Não foi estabelecida meta de } \\
\text { redução ou aumento }\end{array}$ & $\begin{array}{l}\text { Houve investimento em } \\
\text { reformas }\end{array}$ \\
\hline 2017 & $\begin{array}{l}\text { Inserir compras sustentáveis } \\
\text { para os contratos firmados, }\end{array}$ & \\
& $\begin{array}{l}\text { gerenciar os resíduos da da } \\
\text { construção civil, eficiência } \\
\text { energética, acessibilidade, uso }\end{array}$ & Meta Cumprida parcialmente \\
& $\begin{array}{l}\text { racional da água, construção } \\
\text { sustentável, descarte de de } \\
\text { lâmpada. }\end{array}$ & \\
\hline
\end{tabular}

Fonte: Elaboração Própria com base no Relatório de Desempenho do PGLS do TJTO Ano-Base 2016 e 2017

Não foram estabelecidas metas para o ano de 2016, muito embora tenham informado que houve investimento em reformas.

Para as metas fixadas para o ano 2017, houve o cumprimento parcial.

13. Gestão da Educação Socioambiental: Sensibilização e capacitação do corpo funcional e força de trabalho auxiliar, quantidade de ações de sensibilização e capacitação por ano (PLS, 2016).

Objetivo: Produzir conhecimento sobre a sustentabilidade, sensibilizar o corpo funcional acerca da temática e contribuir para instituição da política ambiental (PLS, 2016).

Quadro 17 - Gestão da Educação Socioambiental

\begin{tabular}{|l|l|l|l|}
\hline & Meta & Desempenho \\
\hline 2016 & $\begin{array}{l}\text { Elaboração do Plano de } \\
\text { Capacitação. Não foram }\end{array}$ & $\begin{array}{l}\text { Plano de Capacitação } \\
\text { cumprido. Ações foram } \\
\text { estabelecidas } \\
\text { quantitativas }\end{array}$ & metas \\
desenvolvidas
\end{tabular}


\begin{tabular}{|l|l|l|}
\hline 2017 & Elaborar Plano de Educação & Meta Cumprida
\end{tabular}

Socioambiental

Fonte: Elaboração Própria com base no Relatório de Desempenho do PGLS do TJTO Ano-Base 2016 e 2017

Para o ano de 2016 foi elaborado um Plano de Capacitação para os servidores, sem indicação de metas a serem atingidas, sendo que o Plano de Capacitação foi confeccionado e informam que as ações foram desenvolvidas.

No ano de 2017 fixaram a elaboração do Plano de Educação Socioambiental, tendo a meta sido cumprida.

Ao final da divulgação de cada relatório de desempenho novas metas são estabelecidas para o ano subsequente, de forma a possibilitar o monitoramento dos indicadores traçados para a operacionalização da implementação da gestão socioambiental no TJTO.

As temáticas referentes à redução de papel, copos descartáveis, água engarrafadas, qualidade de vida no trabalho, gestão da educação socioambiental, superou ou atingiu as metas impostas nos anos de 2016 e 2017, o que pode ser considerado um avanço na implementação da gestão sustentável no Tribunal.

Contudo, o mesmo não pode ser dito em relação às temáticas referentes à gestão dos serviços de limpeza, consumo de combustível e de frota de veículos, visto que não conseguiram atingir as metas estabelecidas nem no ano de 2016, nem no ano de 2017.

Fato curioso nos deparamos ao realizar a análise apresentada para a gestão de resíduos, visto que no ano de 2016 não foram estabelecidas metas e para o ano de 2017 não houve informações por parte da Diretoria responsável para contemplação no referido relatório, o que denota a falta de engajamento e ou falha quanto ao monitoramento desta temática.

Um fator que pode ter causado uma dificuldade para o cumprimento das metas estabelecidas para o ano de 2017, conforme relatado pelo Presidente da Comissão Gestora do Plano de Logística Sustentável do Tribunal foi o aumento das tarifas públicas, da inflação e contingenciamento orçamentário (Relatório de Desempenho do Plano de Logística Sustentável, 2017).

Como visto, muito embora se tenha metas e objetivos traçados no Plano de Logística Sustentável os seus resultados nem sempre são como o esperado, seja pelas razões expostas pelo Presidente do Tribunal, ou seja pelo fato, de que as metas propostas não vendo sendo alcançadas em sua totalidade. 
$\mathrm{Na}$ seção seguinte, realizamos a análise dos questionários aplicados com os servidores responsáveis pela unidades de chefias do órgão e com membros do Núcleo de Gestão Socioambiental e Comissão Gestora do Plano de Logística Sustentável, o que possibilitará complementar a análise de como a implementação da gestão socioambiental está ocorrendo no Tribunal.

\subsection{Análise dos Dados Obtidos a Partir da Aplicação dos Questionários}

Nesta subseção será analisada o processo de institucionalização da gestão sustentável no Tribunal de Justiça do Tocantins, com base em dados provenientes dos questionários aplicados aos servidores que possuem cargos de chefias no órgão, e membros da Comissão do Núcleo de Gestão Socioambiental e Comissão Gestora do Plano de Logística Sustentável do TJTO.

O objetivo é identificar a percepção da comissão e dos demais servidores sobre a institucionalização da gestão socioambiental no Tribunal de Justiça do Tocantins.

Os questionários foram aplicados aos membros do Núcleo de Gestão Socioambiental e membros da Comissão Gestora do Plano de Logística Sustentável do TJTO, no qual nos reportaremos na análise a seguir como comissão ambiental. Também foram aplicados questionários aos Diretores e Chefes de Divisões ligados às Diretorias do Tribunal, cuja denominação recebida será de servidores.

Salienta-se, que o Núcleo de Gestão Socioambiental é composto por três membros e a Comissão Gestora do Plano de Logística Sustentável por 8 membros, dos quais há coincidência de 1 membro que pertence às duas comissões, sendo disponibilizados 10 questionários ao grupo, tendo 8 membros respondido aos questionamentos realizado.

Por sua vez, considerando que o Tribunal de Justiça do Tocantins que é composto por 7 diretorias, cuja responsabilidade fica a cargo dos diretores e chefes de divisões, que representam apresentam 51 cargos, dos quais 32 responderam o questionário aplicado, sendo que os demais não responderam e ou não tiveram disponibilidade para recebê-los.

Salienta-se ainda, que a escolha dos servidores se restringiu aos ocupantes dos cargos de chefia visto que competem aos gestores dos órgãos a disseminação das ações desenvolvidas e motivação para o engajamento dos seus subordinados, com base na análise da percepção dos gestores é possível tomar por base a percepção dos demais servidores técnicos administrativos. 


\subsubsection{GT 1 - Conhecimento da temática e legislação ambiental}

A arguição a respeito do conhecimento da temática e legislação ambiental foi realizada apenas com os servidores do Tribunal de Justiça (excetuando os membros da comissão ambiental), o que se faz com base no "Questionário A", constante do Apêndice B desta pesquisa.

Salienta-se ainda, que todos os servidores que se prestaram a responder o questionário, possuem ensino superior com formação nos cursos de Administração e Direito.

Inicialmente buscou-se identificar o nível de consciência dos servidores a respeito da temática legislação ambiental, que numa classificação de "péssimo, ruim, bom, ótimo e excelente", o escore final foi de bom, visto que $63 \%$ dos servidores assinalaram essa opção, $13 \%$ marcaram a opção ótimo, $9 \%$ ruim e 3\% excelente.

Buscando-se aferir o conhecimento referente às questões socioambientais, como os temas: sustentabilidade e gestão ambiental, práticas de sustentabilidade ambiental, competências da comissão socioambiental instalada no órgão, conhecimento sobre a agenda Ambiental na Administração Pública, Plano de Logística Sustentável do órgão, uso sustentável de recursos naturais e bens públicos e da gestão adequada dos resíduos gerados, verificou-se que $41 \%$ dos temas são conhecidos plenamente, $38 \%$ conhecem parcialmente, $21 \%$ não conhecem os temas, conforme dados representados na Tabela 2:

Tabela 2 - Resultado dos Questionários - Temática Socioambiental

\begin{tabular}{|c|c|c|c|}
\hline QUESTÕES & SIM & $\mathrm{NA \tilde {O }}$ & $\begin{array}{c}\text { Conheço } \\
\text { Parcialmente }\end{array}$ \\
\hline Você conhece os temas sustentabilidade e gestão ambiental? & $\begin{array}{c}20 \\
67 \%\end{array}$ & $\begin{array}{c}0 \\
0 \%\end{array}$ & $\begin{array}{c}10 \\
33 \%\end{array}$ \\
\hline Você conhece práticas de sustentabilidade ambiental? & $\begin{array}{c}24 \\
80 \%\end{array}$ & $\begin{array}{c}1 \\
3 \%\end{array}$ & $\begin{array}{c}5 \\
17 \%\end{array}$ \\
\hline $\begin{array}{l}\text { Você tem conhecimento a respeito da Comissão } \\
\text { Socioambiental no TJ/TO? }\end{array}$ & $\begin{array}{c}20 \\
63 \%\end{array}$ & $\begin{array}{c}8 \\
25 \%\end{array}$ & $\begin{array}{c}4 \\
13 \%\end{array}$ \\
\hline $\begin{array}{l}\text { Você conhece as competências e ações desenvolvidas pela } \\
\text { Comissão Socioambiental TJ/TO }\end{array}$ & $\begin{array}{c}7 \\
23 \%\end{array}$ & $\begin{array}{c}8 \\
27 \%\end{array}$ & $\begin{array}{c}15 \\
50 \%\end{array}$ \\
\hline $\begin{array}{l}\text { Você conhece o Programa Agenda Ambiental na } \\
\text { Administração Pública }-\mathrm{A} 3 \mathrm{P} ?\end{array}$ & $\begin{array}{c}5 \\
17 \%\end{array}$ & $\begin{array}{c}14 \\
48 \%\end{array}$ & $\begin{array}{c}10 \\
34 \%\end{array}$ \\
\hline Você conhece o Plano de Logística Sustentável do TJ/TO? & $\begin{array}{c}7 \\
24 \% \\
\end{array}$ & $\begin{array}{c}9 \\
31 \% \\
\end{array}$ & $\begin{array}{c}13 \\
45 \%\end{array}$ \\
\hline $\begin{array}{l}\text { Você tem conhecimento acerca do "uso sustentável de } \\
\text { recursos naturais e bens públicos" na Administração Pública? }\end{array}$ & $\begin{array}{c}12 \\
39 \% \\
\end{array}$ & $\begin{array}{c}4 \\
13 \% \\
\end{array}$ & $\begin{array}{c}15 \\
48 \% \\
\end{array}$ \\
\hline Você tem conhecimento acerca da gestão adequada de & 4 & 8 & 19 \\
\hline
\end{tabular}




\begin{tabular}{l|c|c|c}
\hline resíduos gerados na Administração Pública? & $13 \%$ & $26 \%$ & $61 \%$ \\
\hline TOTAL & $99(41 \%)$ & $52(21 \%)$ & $91(38 \%)$ \\
\hline
\end{tabular}

Elaborado pela autora com base nos dados da pesquisa

Destaque-se que o índice de conhecimento quanto às competências e ações da Comissão Socioambiental, Programa A3P, Plano de Logística Sustentável e gestão adequada dos resíduos gerados na Administração, conforme os dados apontados na Tabela 2, são poucos conhecidos, o que corresponde uma limitação para a implementação da gestão sustentável no Tribunal, pois os temas acima descritos são a base para a efetivação da implementação da gestão socioambiental, o que denota a falta de uma sensibilização e conhecimento por parte dos servidores sobre do assunto.

Buscando-se aferir a noção dos servidores a respeito das normas que regem a implantação das práticas socioambientais no Poder Judiciário e Tribunal de Justiça do Estado, constatou-se que de alguma forma que todas as normas apontadas na questão 3 do questionário, constante do Apêndice $\mathrm{B}$, são conhecidas pelos servidores, conforme índices demonstrado no gráfico 1 :

Gráfico 1 - Normativos que Orientam Implantação Práticas Ambientais

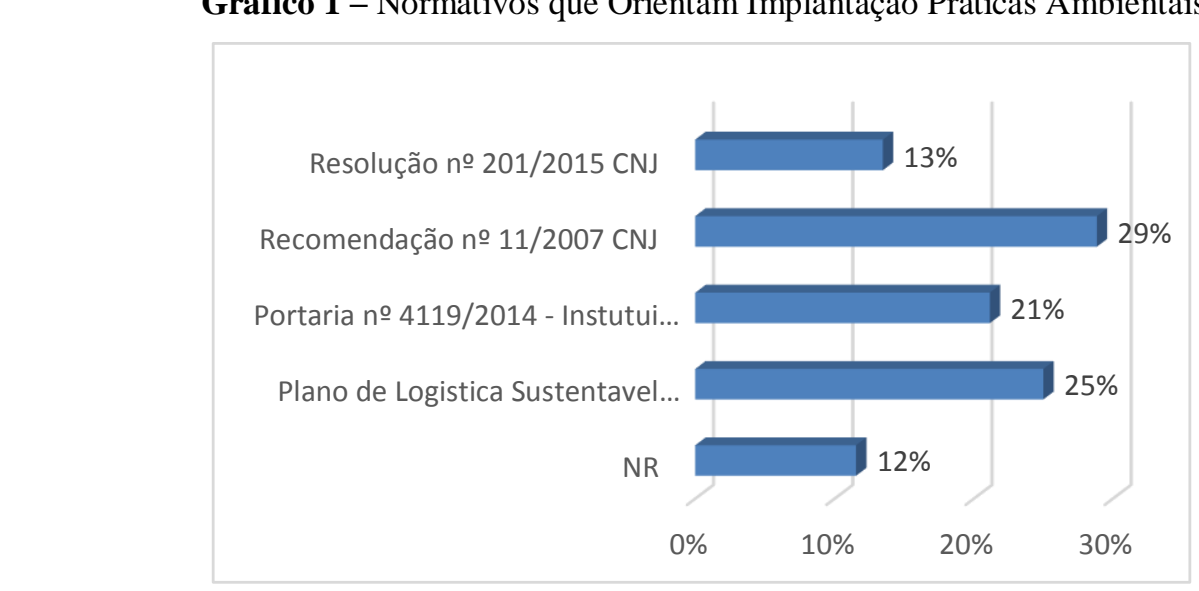

Fonte: Elaborado pela autora a partir dos dados obtidos na pesquisa

Em análise dos índices apontados no gráfico 3, pode-se perceber que a Recomendação $\mathrm{n}^{\circ}$. 11/2007 do CNJ, é pouco conhecida pelos servidores (13\%) e que $12 \%$ dos servidores não assinalaram nenhuma das alternativas, demonstrando não conhecerem nenhuma das normas. Não conhecer a Recomendação $n^{\circ}$. 11/2007 não pode ser considerada como uma limitação para implementação da gestão sustentável no TJTO, haja vista que, trata-se de uma recomendação aos Tribunais que devem adotar medidas necessárias para ao desenvolvimento de práticas em seu âmbito, sendo que tais medidas 
chegarão aos servidores por atos próprios do Tribunal. Contudo, pode ser considerado como limitador o fato de uma parcela dos servidores não conhecerem nenhuma legislação à respeito da temática.

$\mathrm{O}$ que pode trazer uma preocupação e ser considerado como um limitador é o fato de $25 \%$ dos servidores afirmarem que conhecem o PLS do TJTO, mas se contrapormos à questão anterior (questão 2, do Questionário A, Apêndice B) a maioria dos servidores afirmaram que não conheciam o PLS voltado para o órgão, mas na questão 3 afirmam possuir conhecimento, o que denota que sabem da sua existência, mas não possuem ciência do conteúdo do PLS/TJTO propriamente dito.

O primeiro passo para a implementação de uma gestão sustentável em qualquer ambiente de trabalho e ou Administração Pública é o conhecimento da temática levado àqueles que deverão executar as ações, programas e metas estabelecidas, pois só pode ser efetivo e inserido na rotina dos trabalhos aquilo que é conhecido e perceptível.

A pesquisa nos revela que a falta de conhecimento dos servidores sobre a temática e legislação a respeito do tema, representa uma limitação que pode ocasionar o comprometimento da institucionalização da gestão sustentável no Tribunal de Justiça do Tocantins, devendo o órgão rever o método de conscientização a respeito da temática através de capacitação dos servidores, matérias divulgadas no site do órgão, uso da ferramenta como Zap Justiça (ferramenta utilizada pelo Tribunal para divulgação de notícias por meio de vídeos curtos de aproximadamente 3 minutos) e divulgação de informações pelo Sistema Eletrônico de Informações - SEI, disparados aos servidores.

4.3.2. GT 2 - A comissão do núcleo de gestão socioambiental e a sua relação com a instituição

Visando identificar a relação da comissão socioambiental com a Instituição pesquisada, foi abordado questionamento a respeito do tema, tanto no questionário $\mathrm{A}$ (Apêndice B) aplicado aos membros da própria comissão ambiental, quanto no questionário B (Apêndice C), aplicado aos servidores.

Neste mister, para melhor compreensão subdividiremos a análise dos dados obtidos primeiramente sob a ótica da comissão ambiental e depois dos servidores, para ao final apresentarmos o diagnóstico. 
Insta rememorar que a instituição da comissão socioambiental e comissão gestora do PLS é de caráter obrigatório aos Tribunais por imposição do CNJ, conforme já analisado no item 2.4 desta dissertação, logo que, a imposição foi devidamente observada pelo Tribunal de Justiça do Tocantins, ao instituir normas para cumprimento das recomendações insertas, criando por meio da Resolução nº 22 de 2015 o Núcleo de Gestão Socioambiental e por meio da Portaria no . 3.943/2015 a Comissão Gestora do Plano de Logística Sustentável.

$\mathrm{Na}$ visão da comissão há comprometimento da Instituição com as questões ambiental e implantação das práticas ambientais como um todo, porém, o nível da institucionalização da gestão sustentável numa escala entre "inicial, médio e avançado" encontra-se no nível entre inicial (50\%) a médio (38\%), visto que somente $13 \%$ entendem que o nível da institucionalização da gestão sustentável estaria em estágio avançado.

Questionado quanto ao comprometimento dos departamentos no que concerne a incorporação das práticas socioambientais, numa escala de "sempre, na maioria das vezes, raramente e nunca" para a comissão ambiental, raramente (63\%) ocorre o comprometimento dos departamentos, pois para $75 \%$ dos membros da comissão existe muita resistência, dificuldade ou negação para incorporação das práticas e mudanças de hábitos por parte do corpo funcional e demais colaboradores.

Para a maioria dos membros da comissão ambiental (63\%) não há previsão e/ou disponibilização orçamentária destinada ao desenvolvimento de ações e práticas socioambientais no âmbito do TJ/TO.

Questionado sobre a existência de algum canal de acesso à população/sociedade no qual sejam divulgadas as informações relacionadas às práticas socioambientais, bem como, para reclamações, sugestões ou críticas, afirmaram que o canal existe, podendo as manifestações ocorrerem por meio de e-mail da comissão, ouvidoria e ou corregedoria.

Visando identificar quais ações são necessárias para que ocorra efetivamente a institucionalização da gestão sustentável no Tribunal, foi questionado em pergunta aberta à comissão, quais ações seriam necessárias, tendo os mesmos respondido pela necessidade de se "promover educação ambiental", que houvesse "comprometimento dos servidores", “da alta administração/presidência com a temática" e "promoção de palestras e cursos".

De acordo com 50\% dos membros da comissão ambiental, apenas alguns departamentos tem conhecimento a respeito das ações desenvolvidas por eles e $75 \%$ afirmam que suas ações só são reconhecidas em razão do caráter obrigatório. Afirmam 
ainda (75\%), que para a Administração Superior do Tribunal de Justiça do Tocantins as práticas socioambientais possuem caráter obrigatório, sendo questionado se "sempre, na maioria das vezes, raramente ou nunca" envidam esforços no sentido de estimular as atividades da comissão e a efetivação das práticas ambientais, foi reconhecido que na maioria das vezes $(75 \%)$ o estímulo ocorre por parte do órgão.

Questionado à comissão ambiental o que colaboraria para o desempenho e funcionamento das suas ações, para a maioria dos membros "o funcionamento está adequado aos objetivos propostos" que "está funcionando a contento"; que "as atividades estão sendo realizadas conforme foi convocada"; que "as competências da comissão são restritas de modo que não é autorizada implementar ações, mas apenas apontar soluções possíveis". Mas, foi sugerido por 1 membro que "houvesse disposição de tempo integral a atividade, a fim de que tivessem mais dedicação à matéria" o por outro que seria necessário dotar a comissão gestora do PLS de "caráter permanente e com membros exclusivos para desempenhar o trabalho".

A comissão ao ser invocada a dar opinião a respeito de quais ações deveriam ser implementadas por eles para que houvesse efetividade quanto as práticas realizadas, responderam de forma unânime, que a comissão não desempenha o papel de implementar ações, mas apenas sugere as diretorias o que deve ser realizado; que o papel da comissão é apenas monitorar e planejar, a execução é por conta das Diretorias; que não possui o caráter de implementar ações, mas apenas sugeri-las as Diretorias; que a comissão não pode implementar ações, uma vez que não tem poder de gestão para tal; que as competências da comissão são restritas de modo que não é autorizada a implementar ações, mas apenas apontar soluções possíveis; que a comissão é responsável por elaborar, revisar e propor ações contidas no PLS; e não está autorizada a implementar ações.

O mesmo questionamento apresentado à comissão socioambiental foi realizado aos servidores, para que estes dispusessem a respeito de quais ações deveriam ser implementadas pela comissão para favorecer a efetividade da questão socioambiental no Tribunal, tendo os mesmos de forma sintética, apontado a necessidade de:

a) sensibilização para envolver os servidores sobre a temática;

b) adoção de logística reversa, uso telefone "spak", de lâmpadas sustentáveis, uso de lixeiras para coleta seletiva, papel reciclado, redução de papel, copos plásticos e garrafas;

c) dar publicidade às ações por meio de campanhas; 
d) acompanhamento das ações desenvolvidas;

As sugestões apresentadas refletem os anseios dos servidores quanto à necessidade de divulgação e adoção de medidas que permitem o engajamento por parte destes nas atividades socioambiental. Sendo que os limitadores apresentados refletem a necessidade de uma divulgação, capacitação e comunicação institucional sobre a temática.

\subsubsection{GT 3 - A questão socioambiental e a institucionalização no TJTO}

Buscou-se ainda identificar junto à comissão ambiental e aos servidores como ocorreu a institucionalização da gestão sustentável, investigando se foi realizado diagnóstico para identificação dos prováveis impactos ambientais decorrentes de suas atividades, se é realizado levantamento estatístico das práticas socioambientais e se estes são disponibilizados pela Comissão do Núcleo de Gestão Socioambiental.

A comissão ambiental ao ser questionada sobre as etapas despendidas para que ocorresse a implantação da gestão sustentável no Tribunal, foi unânime ao afirmar que realizaram:

a) Diagnóstico socioambiental;

b) Planejamento, elaboração e implementação de indicadores e metas;

c) Sensibilização de servidores e colaboradores quanto às práticas socioambientais;

d) Capacitação de servidores e colaboradores;

e) Monitoramento das ações implementadas;

f) Avaliação das práticas efetivadas;

g) Revisão de ações e práticas;

h) Prestação de contas à sociedade (relatórios com resultados obtidos).

Afirma ainda a comissão ambiental, de forma unânime, que quando da institucionalização das práticas ambientais os itens acima elencados foram abordados de forma individualizada e por departamento sendo que a sensibilização dos servidores e a prestação de contas ocorram por meio de uma abordagem geral.

Contudo, ao comparar as respostas da comissão ambiental com a dos servidores é possível verificar que ações desenvolvidas pela comissão ambiental não foi perceptível por todos os servidores, haja vista que, 55\% afirmaram que não foi realizado diagnóstico para a identificação dos prováveis impactos ambientais decorrentes de suas atividades, sendo que 
$54 \%$ afirmaram ter conhecimento quanto a realização de levantamento estatístico quanto às práticas socioambientais realizadas, enquanto que $50 \%$ afirmam ter havido disponibilização da mensuração e ou levantamento dos dados.

As respostas obtidas para o presente grupo temático com os servidores, corroboram as limitações detectadas quanto ao conhecimento dos mesmos a respeito das práticas exercidas pela comissão ambiental para a institucionalização da questão socioambiental no TJTO.

Salienta-se que a pesquisa foi aplicada com os diretores e servidores que exercem chefias nas divisões ligadas às diretorias do Tribunal, ou seja, com servidores responsáveis por seus setores. O índice de desconhecimento quanto às ações preliminares para a institucionalização das questões socioambientais na forma apresentada, pode ser considerada uma fragilidade, que poderá ter ligação direta com as práticas a serem implementadas, visto que o primeiro passo para as ações é o planejamento, cujas atividades não são de conhecimento daqueles que irão desenvolver as práticas a serem implementadas.

Contudo, a fragilidade detectada não limita o processo ao insucesso, haja vista que, ações posteriores com comprometimento da Instituição, ações do Núcleo de Gestão Socioambiental e da Comissão Gestora do Plano de Logística Sustentável e os próprios resultados estabelecidos no Plano de Logística Sustentável, podem demonstrar a efetividade quanto às práticas sustentáveis desenvolvidas no órgão.

\subsubsection{GT 4 - Sensibilização e capacitação socioambiental no TJTO}

Questionou-se à comissão ambiental e aos servidores a forma pela qual a sensibilização e capacitação socioambiental é disseminada no âmbito do Tribunal, para possibilitar a averiguação dos reflexos das ações sustentáveis implementadas no TJTO.

A comissão ambiental ao ser questionada quanto ao modo como ocorre a sensibilização e capacitação socioambiental, dentre as opções indicadas na questão 17 do Questionário B, apresentada no Apêndice C, manifestou que a sensibilização ocorre por meio de: cursos e treinamentos (100\%), palestras (100\%), folders e/ou cartazes $(75 \%)$, email institucional (75\%) e fóruns ou debates (38\%), sendo sugerido ainda vídeos institucionais como método eficaz para à sensibilização. 
A comissão ambiental foi unânime ao afirmar que colaboram com o acesso às informações, esclarecimentos e sensibilização dos servidores tanto com as questões práticas, quanto as questões que envolvem as normativas socioambientais, porém quando questionados se as informações disponibilizadas pela comissão são suficientes e eficazes para a incorporação das práticas $63 \%$ dos servidores entendem que sim enquanto que $38 \%$ entendem que precisam melhorar.

Perquirido aos servidores como se obtém conhecimento quanto às práticas e normativas a despeito da sustentabilidade, $31 \%$ informaram que o conhecimento vem por meio de informativos ou orientações em e-mail institucional, $28 \%$ apontaram que toma ciência por meio de publicações no diário da justiça, 19\% dos servidores informaram que o conhecimento advém de cursos e treinamentos, e outros por meio do Sistema Eletrônico de Informações - SEI (processo administrativo digital) com 16\%, sendo que apenas $6 \%$ informaram que as informações são conhecidas por meio da comissão socioambiental instituída, conforme pode-se verificar nos os resultados da Tabela 3:

Tabela 3 - Resultado dos Questionários - Meio de Divulgação de Práticas e Normativos Socioambientais

\begin{tabular}{l|c}
\hline Meio de divulgação de práticas e normativos socioambientais & $\begin{array}{l}\text { Percentual de conhecimento dos } \\
\text { entrevistados (\%) }\end{array}$ \\
\hline 1 Informativos ou orientações em e-mail institucional & $31 \%$ \\
\hline 2 Cursos e Treinamentos & $19 \%$ \\
\hline 3 Publicação no Diário da Justiça & $28 \%$ \\
\hline 4. Comissão Socioambiental (página ou blog) & $6 \%$ \\
\hline 5 Processo Administrativo Digital & $16 \%$ \\
\hline
\end{tabular}

Elaborado pela autora com base nos dados da pesquisa

Os servidores ainda apontaram que o conhecimento sobre a temática é adquirido e levado até eles por meio de reuniões, assuntos divulgados nos sites, portal da transparência, visitas da Diretoria de Infraestrutura que desenvolveu um trabalho de conscientização em todos os departamentos, projetos desenvolvidos e conversas informais com servidores e membros da comissão ambiental.

Ademais, quando perguntado se a comissão socioambiental contribui na sensibilização e capacitação da temática com informações e esclarecimentos, numa escala entre "sempre, às vezes e nunca", 33\% responderam às vezes, 27\% nunca, 27\% sempre, sendo que $13 \%$ não responderam. Deste modo, para a maioria dos servidores a comissão contribui com o trabalho de sensibilização, contudo, ao contrapor com a questão acima, 
onde foi apontado os meios que esta divulgação ocorre, apenas $6 \%$ elevaram créditos à comissão.

Sendo que quando questionado o meio mais utilizado para a consecução da sensibilização e capacitação no âmbito institucional, foi apontado dentre os métodos indicados (cursos e treinamentos, folders e/ou cartazes, orientações por e-mail institucional, fóruns ou debates), os folders e ou cartazes como o modo mais utilizado $33 \%$, seguido de cursos e treinamentos $17 \%$.

Ademais, questionados se as informações disponibilizadas pela comissão socioambiental são suficientes e eficazes para a incorporação das práticas socioambientais para a maioria dos servidores $68 \%$, as práticas utilizadas precisam melhorar para que ocorra a incorporação das referidas ações.

Em complementação à pergunta acima e para finalização do bloco de perguntas, questionados se existe sensibilização ambiental orientada no Tribunal ao servidores, colaboradores e prestadores de serviços a resposta obtida foi de que existe parcialmente $(53 \%)$.

Diante das declarações colhidas, foi possível constatar que o conhecimento e sensibilização sobre a temática é levado aos servidores do TJ de forma esparsa, sendo os mecanismos utilizados de modo aleatório, o que denota que não há uma divulgação maciça, concentrada sobre o tema, transparecendo que esta ocorre de forma vaga, dispersa e gradativa entre os servidores, o que significa uma fragilidade constatada na institucionalização da gestão sustentável no órgão.

Ainda tiveram $39 \%$ dos servidores que não apontaram qualquer instrumento a respeito de como ocorre a capacitação e sensibilização, o que pode ser interpretado como desconhecimento, desinteresse ou déficit quanto às ações realizadas, deixando ainda mais em evidência a limitação acima apontada.

Assim, diante das proeminências constatadas, é necessário que o Tribunal desenvolva um plano de capacitação, que possibilite a comunicação, conscientização, disseminação das práticas que favoreçam o processo de institucionalização da gestão sustentável. 


\subsubsection{GT 5 - Práticas socioambientais}

Por fim, buscou-se conhecer ainda, as práticas socioambientais conhecidas e implementadas no Tribunal, como estão sendo incorporadas, as principais dificuldades, as potencialidades, seus aspectos e características, sob à ótica individual dos membros da comissão e dos servidores do TJTO.

Questionado aos servidores se são desenvolvidas ações ou práticas socioambientais no âmbito do TJ/TO, 78\% reconheceram que ações voltadas para sustentabilidade são praticadas e de forma permanente, conforme índice apontado no Gráfico 2:

Gráfico 2 - Eficácia disponibilização das informações comissão socioambiental

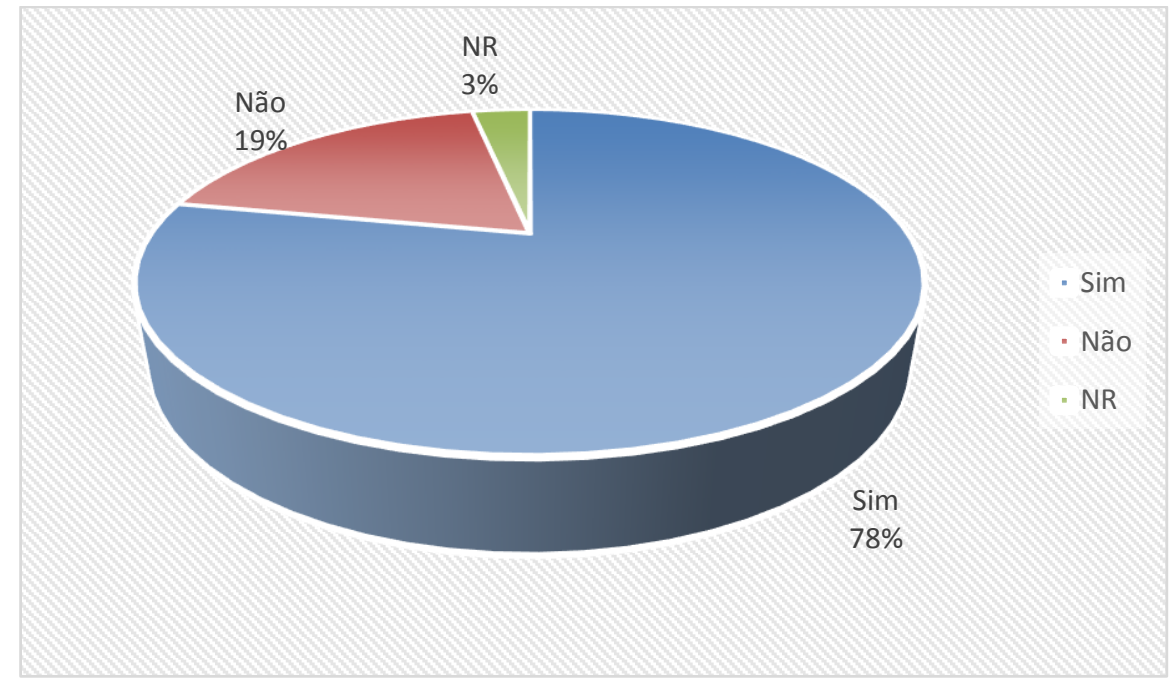

Fonte: Elaborado pela autora com base nos dados da pesquisa

Vislumbra-se que $19 \%$ dos servidores não reconhecem que práticas e ou ações socioambientais são exercidas no órgão, o que denota que não é claro a todo o corpo administrativo que algumas medidas adotadas na Instituição estão relacionadas às práticas ambientais.

Tentado verificar o grau de envolvimento dos servidores quanto às práticas a serem exercidas, foi perguntado se estas ocorrem de forma voluntária em razão da consciência ambiental dos mesmos, ou de forma obrigatória em razão do cumprimento de imposição de normas, para a maioria dos servidores (44\%), as práticas ocorrem respaldadas nas duas razões citadas. 
Mas, questionado se porventura as referidas ações possuíssem caráter voluntário ainda assim continuariam sendo desenvolvidas, para 66\% dos servidores as ações continuariam sendo incrementadas por todos os atores envolvidos na instituição.

Os membros da comissão ambiental comungam da mesma percepção ao afirmarem que as ações ou práticas socioambientais no TJ/TO ocorrem em decorrência da consciência de cada servidor aliado à obrigatoriedade de cumprimento das normas estabelecidas, cujo engajamento para eles se dá $100 \%$ pelos servidores efetivos e requisitados, $50 \%$ pelos terceirizados colaboradores e ainda com a participação da administração superior e estagiários.

Questionado também aos servidores quais os atores efetivamente envolvidos no desempenho das práticas ambientais, foi respondido que o engajamento ocorre tanto por servidores efetivos, quanto por servidores requisitados, estagiários e terceirizados, na proporção apresentada no resultado exposto no gráfico 3:

Gráfico 3 - Percentual de Adesão dos Agentes às Práticas Ambientais nas TJTO

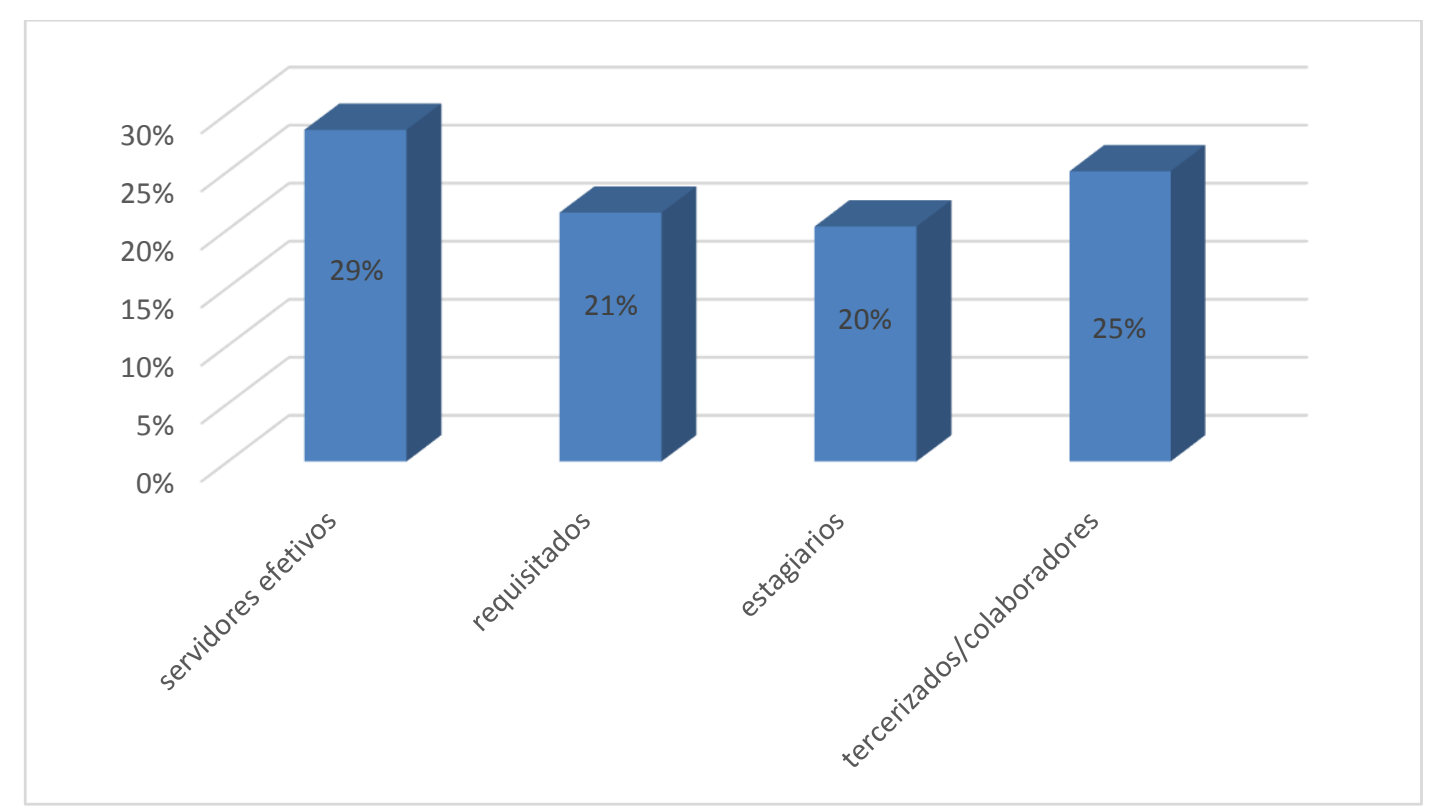

Fonte: Elaborado pelo autor com base nos dados da pesquisa

Como é possível observar todo o corpo técnico do Tribunal é envolvido para consecução das práticas socioambientais, o que contribui para assunção do compromisso com as ações desenvolvidas, podendo ser detectada neste ponto uma potencialidade para a gestão socioambiental ser ampliada e otimizada para atingimento de todos àqueles que desempenham atividades em função do órgão. 
Buscando entender um pouco das dificuldades enfrentadas para a implementação das práticas socioambientais no Tribunal, foi apontado um rol de fatores com possíveis complicadores do processo, do qual restou constatado como sendo empecilho os assinalados no Gráfico 4:

Gráfico 4 - Dificuldades para Implantação de Práticas Socioambientais no TJTO

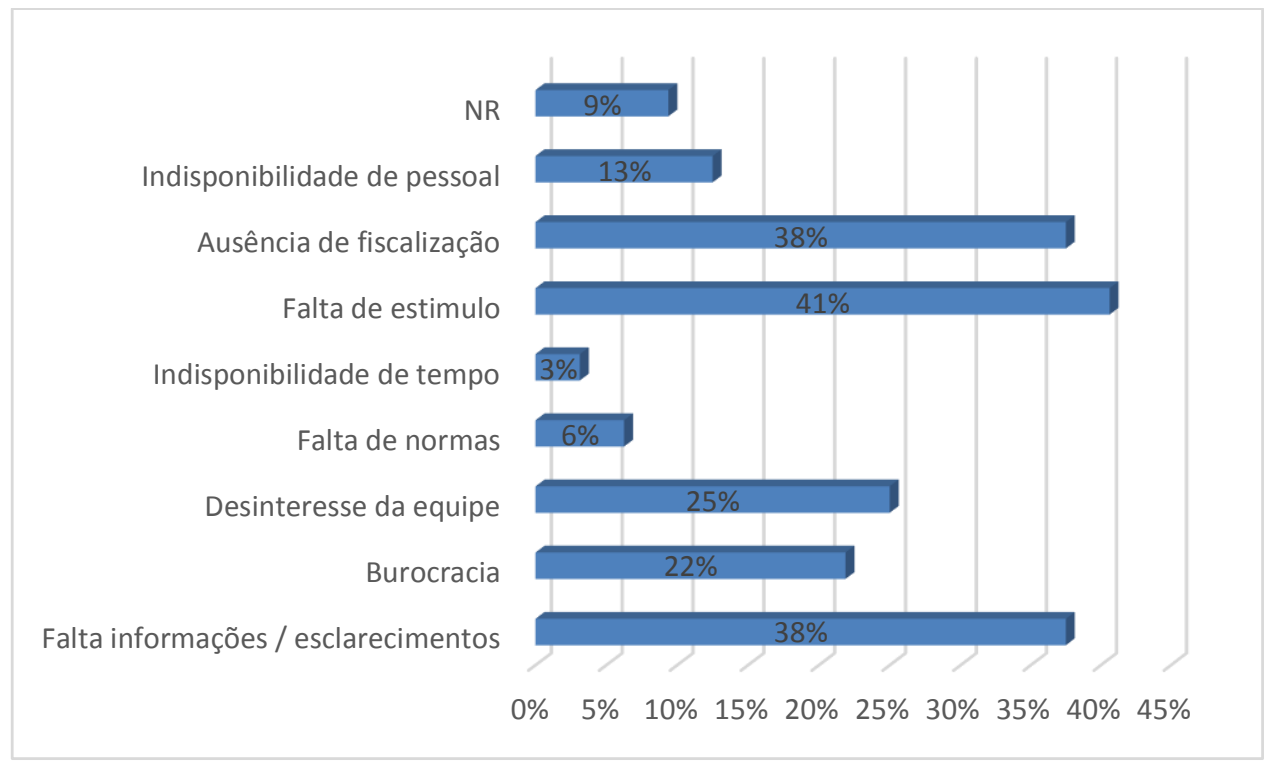

Fonte: Elaborado pelo autor com base nos dados da pesquisa

De acordo com os servidores o maior empecilho estaria na falta de estímulo, apoio ou motivação (41\%), seguido da falta de informações e ou esclarecimentos (38\%) e na ausência de fiscalização efetiva (38\%).

Para a comissão ambiental as maiores dificuldades para a implantação das práticas sustentáveis no TJ/TO em ordem decrescente de assinalização foram: a) indisponibilidade de pessoal (100\%), insuficiência normas (88\%), ausência de fiscalização e burocracia (75\%), dificuldade de informação (50\%), falta de estímulo, apoio ou motivação (38\%), falta de informação e ou esclarecimentos (13\%), falta de tempo (13\%).

Salienta-se que a ordem apontada como fatores determinantes para as dificuldades de implantação das práticas socioambientais é diferente para os servidores e para a comissão ambiental, haja vista que, os servidores apontaram como principal causa falta de estímulo, apoio ou motivação, enquanto que a comissão ambiental aponta falta de informações e esclarecimentos, burocracia e ausência de comprometimento do corpo funcional. 
Apesar da discrepância, tal como foi apresentado, este não pode ser visto como uma fragilidade mas como grande potencial de desenvolvimento, tendo em vista que a comunicação não foi apontada como um entrave para a implantação das ações no Tribunal.

Deste modo, deve-se desenvolver ações que motivem os servidores à realização das atividades sustentáveis, pois a ausência de comprometimento do corpo funcional conforme os dados coletados reside na falta de estímulo, apoio ou motivação, tal qual afirmado pelos servidores, o que pode ser revisto com capacitação, informativos, esclarecimentos sobre o assunto por meio de cursos, palestras, apresentação de manuais.

Buscando conferir ênfase em relação às atividades que representam maiores dificuldades para serem implementadas no Tribunal, foi questionado à comissão ambiental, quais seriam as ações que teriam dificuldades de serem implantas em seu âmbito, sendo apontado "a coleta de água da chuva, devido à falta de previsão no projeto arquitetônico", "coleta de todos os resíduos, por inexistir coleta seletiva na cidade" e energia solar, devido à falta de previsão orçamentária."

Procurou-se buscar ainda junto à comissão ambiental, quais seriam as estratégias importantes para a efetividade das práticas ambientais, das opções apresentadas no item 23, do Questionário B, constante do Apêndice C, todas as opções foram assinaladas, com ênfase no comprometimento de servidores e colaboradores (100\%) e fiscalização e auditoria das práticas exigidas $(75 \%)$.

Gráfico 5 - Ações Instrumentos Estratégias Práticas Socioambientais

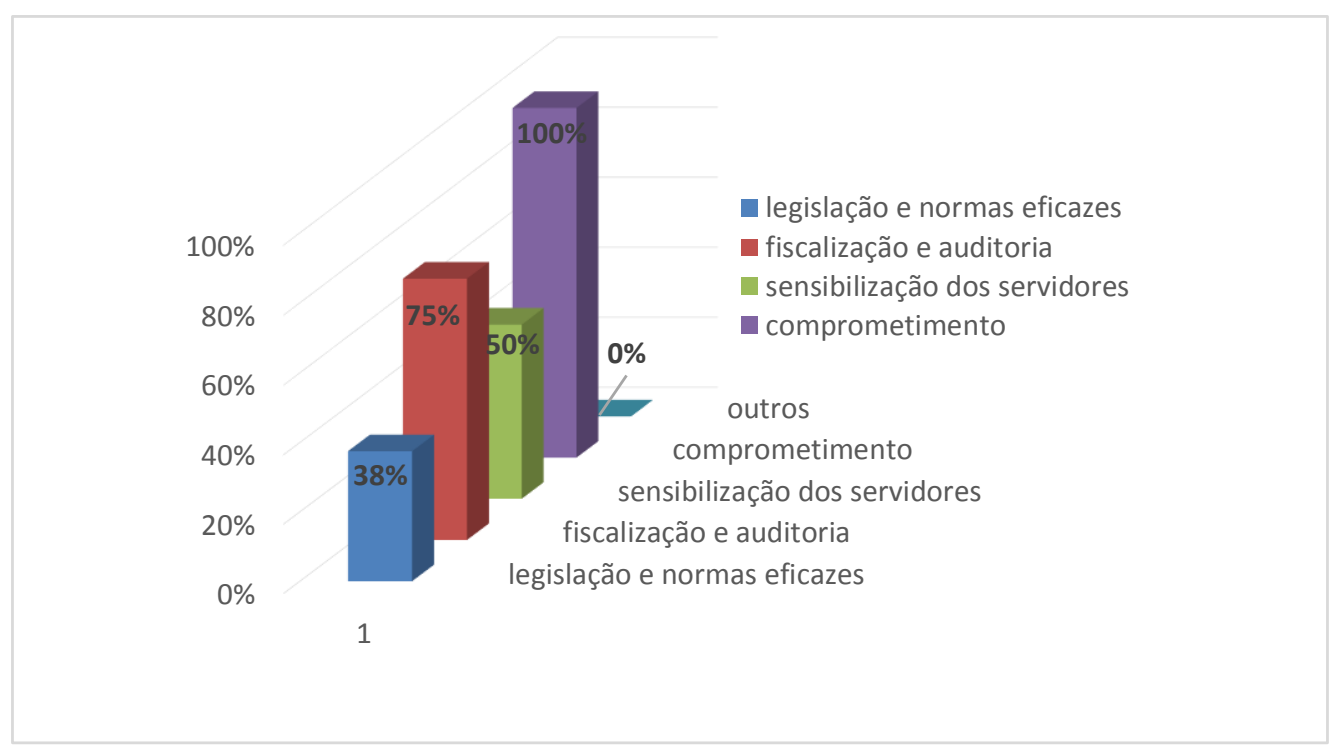

Fonte: Elaborado pelo autor com base nos dados da pesquisa 
Entendem, ainda os membros da comissão ambiental por unanimidade, que as ações e as práticas socioambientais desenvolvidas no âmbito do Tribunal são capazes de minimizar os impactos ambientais negativos, sendo especificado por dois dos membros que as práticas desenvolvidas "contribuem para a utilização racional dos recursos" e ainda "promove a conscientização do corpo funcional sobre a utilização adequada dos recursos disponíveis".

Perguntado aos servidores quais as ações, instrumentos ou estratégias que são importantes para a efetividade das práticas socioambientais no Tribunal de Justiça, a maioria (78\%) respondeu que é a sensibilização do corpo funcional, seguido de $50 \%$ que apontaram fiscalização e auditoria das práticas exigidas, sendo acompanhada de $28 \%$ que veem a legislação e normas eficazes como fatores essenciais para efetivação das práticas mencionadas. Sendo apontado pelos servidores ainda: "a necessidade de se realizar campanhas", "gincanas temática", "modificar a cultura das pessoas", "explorar as datas comemorativas sobre o assunto".

Para 56\% dos servidores as práticas socioambientais implementadas no âmbito do TJ/TO são capazes de minimizar os impactos ambientais negativos e podem ainda, impactar positivamente para além do âmbito institucional com reflexos sociais. E os membros da comissão ambiental foram unânimes em afirmar que derivam da institucionalização das práticas socioambientais "economicidade", "sustentabilidade de recursos naturais", "redução do impacto ambiental”, "eficiência da gestão", "transparência", "moralidade", "sensibilização dos colaboradores" e "qualidade de vida".

Pretendeu-se ainda, enfatizar a temática questionando aos servidores e à comissão ambiental, quais ações na prática estão sendo disseminadas, o que se fez pautada nos eixos temáticos: 1 . Uso racional dos recursos naturais e bens públicos e; 2 . Gestão adequada dos resíduos sólidos, com base nas ações apontadas como adequadas no Programa da A3P, Resolução 201/2015 do CNJ e PLS do próprio Tribunal.

Assim optou-se por investigar algumas ações abalizadas nos indicadores: consumo de energia elétrica, consumo de água, consumo de papel e consumo de copos plásticos no que se refere o uso racional dos recursos naturais e bens públicos, coleta seletiva e gestão de resíduos perigosos no que se refere à gestão adequada dos resíduos sólidos. 
Neste mister, por meio da Tabela 4, é possível verificar o resultado de como a comissão ambiental e os servidores estão visualizando às práticas ligadas ao consumo de energia elétrica no âmbito do órgão:

Tabela 4 - Uso Racional de Recursos Naturais e Bens Públicos - Consumo Energia Elétrica

\begin{tabular}{|c|c|c|c|c|c|c|c|c|}
\hline \multicolumn{9}{|c|}{ PRÁTICAS - USO RACIONAL DE RECURSOS NATURAIS E BENS PÚBLICOS } \\
\hline \multirow[t]{3}{*}{ Especificação } & \multicolumn{4}{|c|}{ Comissão } & \multicolumn{4}{|c|}{ Servidores } \\
\hline & \multicolumn{2}{|c|}{ Conhecida } & \multicolumn{2}{|c|}{ Implementada } & \multicolumn{2}{|c|}{ Conhecida } & \multicolumn{2}{|c|}{ Implementada } \\
\hline & Sim & Não & $\operatorname{Sim}$ & Não & Sim & Não & Sim & Não \\
\hline $\begin{array}{l}\text { Elaboração e aplicação de plano } \\
\text { para redução do consumo e uso } \\
\text { consciente de energia elétrica }\end{array}$ & $\begin{array}{c}8 \\
100 \%\end{array}$ & 0 & $\begin{array}{l}8 \\
100 \%\end{array}$ & 0 & ----- & ----- & ----- & ----- \\
\hline $\begin{array}{l}\text { Monitoramento da energia } \\
\text { consumida }\end{array}$ & $\begin{array}{c}8 \\
100 \%\end{array}$ & 0 & $\begin{array}{l}8 \\
100 \%\end{array}$ & 0 & $\begin{array}{c}21 \\
66 \% \\
\end{array}$ & $\begin{array}{l}11 \\
34 \%\end{array}$ & $\begin{array}{l}18 \\
78 \%\end{array}$ & $\begin{array}{l}5 \\
22 \%\end{array}$ \\
\hline $\begin{array}{l}\text { Promoção da sensibilização de } \\
\text { servidores e colaboradores } \\
\text { quanto ao uso racional de } \\
\text { energia elétrica }\end{array}$ & $\begin{array}{c}8 \\
100 \%\end{array}$ & 0 & $\begin{array}{l}8 \\
100 \%\end{array}$ & 0 & $\begin{array}{c}23 \\
85 \%\end{array}$ & $\begin{array}{l}4 \\
15 \%\end{array}$ & $\begin{array}{l}19 \\
76 \%\end{array}$ & $\begin{array}{l}6 \\
24 \%\end{array}$ \\
\hline 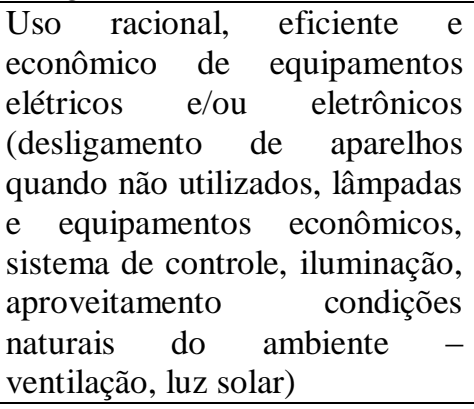 & $\begin{array}{c}8 \\
100 \%\end{array}$ & 0 & $\begin{array}{l}8 \\
100 \%\end{array}$ & 0 & $\begin{array}{c}22 \\
76 \%\end{array}$ & $\begin{array}{l}7 \\
24 \%\end{array}$ & $\begin{array}{l}23 \\
82 \%\end{array}$ & $\begin{array}{l}5 \\
18 \%\end{array}$ \\
\hline $\begin{array}{l}\text { Utilização de energia solar ou } \\
\text { outra forma de energia limpa }\end{array}$ & $\begin{array}{c}8 \\
100 \%\end{array}$ & 0 & 0 & $\begin{array}{l}8 \\
100 \%\end{array}$ & $\begin{array}{c}6 \\
20 \%\end{array}$ & $\begin{array}{l}24 \\
80 \%\end{array}$ & $\begin{array}{ll}3 \\
14 \%\end{array}$ & $\begin{array}{l}19 \\
86 \%\end{array}$ \\
\hline
\end{tabular}

Fonte: Elaborado pela autora a partir dos dados da pesquisa

Os dados na Tabela 4, revelam que para a comissão ambiental todas as práticas listadas para o eixo de consumo de energia elétrica são conhecidas e quase todas implementadas, com a exceção da implementação da utilização de energia solar ou outra forma de energia limpa (100\%) que é conhecida (100\%), porém não implementada (100\%). Contudo, a visão dos servidores é diferente da apresentada pela comissão, haja vista que, para eles nem todas as ações são conhecidas, muito menos são implementadas. Convergindo, portanto, no item relacionado à utilização de energia solar ou outra forma de energia limpa, que para $80 \%$ dos servidores não são conhecidas e $86 \%$ afirmaram não ser implementada, assim como mencionado pela comissão, não é implementada. 
A mesma sistemática foi adotada para a verificação do consumo de água, cujo resultado é apresentado na Tabela 5:

Tabela 5 - Uso Racional de Recursos Naturais e Bens Públicos - Consumo Água

\begin{tabular}{|c|c|c|c|c|c|c|c|c|}
\hline \multicolumn{9}{|c|}{ PRÁTICAS - USO RACIONAL DE RECURSOS NATURAIS E BENS PÚBLICOS } \\
\hline \multirow[t]{3}{*}{ Especificação } & \multicolumn{4}{|c|}{ Comissão } & \multicolumn{4}{|c|}{ Servidores } \\
\hline & \multicolumn{2}{|c|}{ Conhecida } & \multicolumn{2}{|c|}{ Implementada } & \multicolumn{2}{|c|}{ Conhecida } & \multicolumn{2}{|c|}{ Implementada } \\
\hline & Sim & Não & Sim & Não & Sim & Não & Sim & Não \\
\hline $\begin{array}{l}\text { Elaboração e aplicação de plano } \\
\text { para redução do consumo e uso } \\
\text { consciente de água }\end{array}$ & $\begin{array}{c}8 \\
100 \%\end{array}$ & 0 & $\begin{array}{l}8 \\
100 \%\end{array}$ & 0 & ---- & ---- & ---- & ---- \\
\hline $\begin{array}{l}\text { Monitoramento de consumo de } \\
\text { água }\end{array}$ & $\begin{array}{c}8 \\
100 \%\end{array}$ & 0 & $\begin{array}{l}8 \\
100 \%\end{array}$ & 0 & $\begin{array}{l}18 \\
69 \%\end{array}$ & $\begin{array}{l}8 \\
31 \%\end{array}$ & $\begin{array}{l}13 \\
68 \%\end{array}$ & $\begin{array}{l}6 \\
32 \%\end{array}$ \\
\hline $\begin{array}{l}\text { Promoção de sensibilização de } \\
\text { servidores e colaboradores para } \\
\text { o uso racional da água }\end{array}$ & $\begin{array}{c}8 \\
100 \%\end{array}$ & 0 & $\begin{array}{l}8 \\
100 \%\end{array}$ & 0 & $\begin{array}{c}17 \\
68 \%\end{array}$ & $\begin{array}{l}8 \\
32 \%\end{array}$ & $\begin{array}{l}9 \\
45 \%\end{array}$ & $\begin{array}{l}11 \\
55 \%\end{array}$ \\
\hline $\begin{array}{lrr}\text { Uso racional, eficiente } & \text { e } \\
\text { econômico da água (torneiras de } \\
\text { pressão, sensores para } \\
\text { acionamento } & \text { automático; } \\
\text { inspeções das } & \text { instalações } \\
\text { hidráulicas para detectar } \\
\text { vazamentos e } \\
\text { dos recursos) }\end{array}$ & $\begin{array}{c}8 \\
100 \%\end{array}$ & 0 & $\begin{array}{l}8 \\
100 \%\end{array}$ & 0 & $\begin{array}{c}16 \\
67 \%\end{array}$ & $\begin{array}{l}8 \\
33 \%\end{array}$ & $\begin{array}{l}13 \\
59 \%\end{array}$ & $\begin{array}{l}9 \\
41 \%\end{array}$ \\
\hline $\begin{array}{l}\text { Implantação de sistemas de } \\
\text { captação e aproveitamento de } \\
\text { água de chuva com utilização de } \\
\text { água não potável em sistemas } \\
\text { sanitários, lavagens e irrigações } \\
\text { externas }\end{array}$ & $\begin{array}{c}8 \\
100 \%\end{array}$ & 0 & $\begin{array}{l}1 \\
100 \%\end{array}$ & 7 & $\begin{array}{c}6 \\
27 \%\end{array}$ & $\begin{array}{l}16 \\
73 \%\end{array}$ & $\begin{array}{l}0 \\
0 \%\end{array}$ & $\begin{array}{l}19 \\
100 \%\end{array}$ \\
\hline
\end{tabular}

Fonte: Elaborado pela autora a partir dos dados da pesquisa

Assim como ocorreu com as práticas relacionadas ao consumo de energia, ao se falar em consumo de água, vislumbrou-se que para a comissão, $100 \%$ das ações são conhecidas e $90 \%$ foram implementadas, haja vista que, não há implantação de sistemas de captação e aproveitamento de água de chuva com utilização de água não potável em sistemas sanitários, lavagens e irrigações externas. $73 \%$ servidores afirmam não conhecer as práticas discriminadas e $100 \%$ que as mesmas tenham sido implementadas, concordando com a comissão no aspecto da não implantação de sistemas de captação e aproveitamento de água de chuva com utilização de água não potável em sistemas sanitários, lavagens e irrigações externas.

Ao se questionar sobre as práticas relacionadas a respeito do indicador consumo de papel, o resultado é verificável conforme exposto na Tabela 6: 
Tabela 6 - Uso Racional de Recursos Naturais e Bens Públicos - Consumo de Papel

\begin{tabular}{|c|c|c|c|c|c|c|c|c|}
\hline \multicolumn{9}{|c|}{ PRÁTICAS - USO RACIONAL DE RECURSOS NATURAIS E BENS PÚBLICOS } \\
\hline \multirow[t]{3}{*}{ Especificação } & \multicolumn{4}{|c|}{ Comissão } & \multicolumn{4}{|c|}{ Servidores } \\
\hline & \multicolumn{2}{|c|}{ Conhecida } & \multicolumn{2}{|c|}{ Implementada } & \multicolumn{2}{|c|}{ Conhecida } & \multicolumn{2}{|c|}{ Implementada } \\
\hline & Sim & Não & Sim & Não & Sim & Não & Sim & Não \\
\hline $\begin{array}{l}\text { Monitoramento de consumo de } \\
\text { papel usado para impressão e } \\
\text { cópias }\end{array}$ & $\begin{array}{c}8 \\
100 \%\end{array}$ & 0 & $\begin{array}{l}8 \\
100 \%\end{array}$ & 0 & $\begin{array}{c}22 \\
85 \%\end{array}$ & $\begin{array}{l}4 \\
15 \%\end{array}$ & $\begin{array}{l}20 \\
95 \%\end{array}$ & $\begin{array}{l}1 \\
5 \%\end{array}$ \\
\hline $\begin{array}{l}\text { Priorização da utilização papel } \\
\text { reciclado e não clorado }\end{array}$ & $\begin{array}{c}8 \\
100 \%\end{array}$ & 0 & $\begin{array}{l}8 \\
100 \%\end{array}$ & 0 & $\begin{array}{c}6 \\
26 \%\end{array}$ & $\begin{array}{l}17 \\
74 \%\end{array}$ & $\begin{array}{l}2 \\
10 \%\end{array}$ & $\begin{array}{l}18 \\
90 \%\end{array}$ \\
\hline $\begin{array}{l}\text { Otimização de impressões e uso } \\
\text { de papel (impressão frente e } \\
\text { verso ou múltiplas páginas por } \\
\text { folha; manutenção de } \\
\text { impressoras; adoção do modelo } \\
\text { de "ilhas de impressão"; } \\
\text { utilização de "fonte ecológica" } \\
\text { em documentos oficiais) }\end{array}$ & $\begin{array}{c}8 \\
100 \%\end{array}$ & 0 & $\begin{array}{l}8 \\
100 \%\end{array}$ & 0 & $\begin{array}{c}20 \\
77 \%\end{array}$ & $\begin{array}{l}6 \\
23 \%\end{array}$ & $\begin{array}{l}17 \\
71 \%\end{array}$ & $\begin{array}{l}7 \\
29 \%\end{array}$ \\
\hline $\begin{array}{l}\text { Conscientização de servidores e } \\
\text { colaboradores para a real } \\
\text { necessidade de impressão e uso } \\
\text { adequado de papel }\end{array}$ & $\begin{array}{c}8 \\
100 \%\end{array}$ & 0 & $\begin{array}{l}8 \\
100 \%\end{array}$ & 0 & ---- & ---- & ---- & ---- \\
\hline $\begin{array}{l}\text { Utilização de } \\
\text { informatizados, } \\
\text { eletrônicos digitais e de internet } \\
\text { suprindo a necessidade de } \\
\text { impressão e utilização de papel }\end{array}$ & $\begin{array}{c}8 \\
100 \%\end{array}$ & 0 & $\begin{array}{l}8 \\
100 \%\end{array}$ & 0 & $\begin{array}{c}25 \\
100 \%\end{array}$ & 0 & $\begin{array}{l}23 \\
96 \%\end{array}$ & $\begin{array}{l}1 \\
4 \%\end{array}$ \\
\hline
\end{tabular}

Fonte: Elaborado pela autora a partir dos dados da pesquisa

De acordo com os dados obtidos, para a comissão ambiental o Tribunal atingiu $100 \%$ tanto na disseminação para tornar conhecida a prática quanto na implementação das mesmas no que se refere ao consumo de papel. Fato este não perceptível a todos os servidores que responderam os questionários, visto que $74 \%$ demonstraram que não há priorização para utilização de papel reciclado e clorado, concordando tão somente que a utilização de sistemas informatizados (96\%) contribuiu para redução de papel no Tribunal.

Salienta-se neste tocante, que hoje os processos judicias e administrativos do Tribunal são 100\% digital, servindo de modelo para diversos Tribunais em todo o país (site TJTO, 2017).

Por fim, para averiguação das práticas arroladas ao uso racional dos recursos naturais e bens públicos, foi questionado ainda, a respeito das práticas relacionadas ao consumo de copos plásticos, cujo resultado pode ser representado na Tabela 7: 
Tabela 7 - Uso Racional de Recursos Naturais e Bens Públicos - Consumo Copos Plásticos

\begin{tabular}{|c|c|c|c|c|c|c|c|c|}
\hline \multicolumn{9}{|c|}{ PRÁTICAS - USO RACIONAL DE RECURSOS NATURAIS E BENS PÚBLICOS } \\
\hline \multirow[t]{3}{*}{ Especificação } & \multicolumn{4}{|c|}{ Comissão } & \multicolumn{4}{|c|}{ Servidores } \\
\hline & \multicolumn{2}{|c|}{ Conhecida } & \multicolumn{2}{|c|}{ Implementada } & \multicolumn{2}{|c|}{ Conhecida } & \multicolumn{2}{|c|}{ Implementada } \\
\hline & Sim & Não & Sim & Não & Sim & Não & Sim & Não \\
\hline $\begin{array}{l}\text { Promoção da conscientização } \\
\text { para redução do uso de copos } \\
\text { descartáveis e substituição pelo } \\
\text { uso de impressão e utilização de } \\
\text { papel }\end{array}$ & $\begin{array}{c}8 \\
100 \%\end{array}$ & 0 & $\begin{array}{l}8 \\
100 \%\end{array}$ & 0 & $\begin{array}{c}20 \\
77 \%\end{array}$ & $\begin{array}{l}6 \\
23 \%\end{array}$ & $\begin{array}{l}20 \\
83 \%\end{array}$ & $\begin{array}{l}4 \\
17 \%\end{array}$ \\
\hline $\begin{array}{l}\text { Disponibilização de copos } \\
\text { permanentes para servidores e } \\
\text { colaboradores }\end{array}$ & $\begin{array}{c}8 \\
100 \%\end{array}$ & 0 & $\begin{array}{l}8 \\
100 \%\end{array}$ & 0 & $\begin{array}{c}19 \\
76 \% \\
\end{array}$ & $\begin{array}{l}6 \\
24 \% \\
\end{array}$ & $\begin{array}{l}19 \\
79 \%\end{array}$ & $\begin{array}{l}5 \\
21 \%\end{array}$ \\
\hline $\begin{array}{l}\text { Monitoramento do consumo de } \\
\text { copos plásticos }\end{array}$ & $\begin{array}{c}8 \\
100 \%\end{array}$ & 0 & $\begin{array}{l}8 \\
100 \%\end{array}$ & 0 & $\begin{array}{c}10 \\
40 \%\end{array}$ & $\begin{array}{l}15 \\
60 \%\end{array}$ & $\begin{array}{l}10 \\
53 \%\end{array}$ & $\begin{array}{l}9 \\
47 \%\end{array}$ \\
\hline
\end{tabular}

Fonte: Elaborado pela autora a partir dos dados da pesquisa

Para a comissão as ações para promover a conscientização para redução do uso dos copos descartáveis, a troca por copos permanentes e o monitoramento do consumo de copos, são $100 \%$ conhecidos e integralizados. A maioria dos servidores (83\%) conhecem e reconhecem a implementação da prática de conscientização e da disponibilização de copos permanentes (79\%), sendo que $60 \%$ afirmam não haver monitoramento do consumo de copos.

Neste sentido, com base nos dados extraídos das Tabelas 4, 5, 6 e 7 é possível compararmos as práticas conhecidas e àquelas praticadas correspondentes as ações apontadas para o consumo de energia elétrica, consumo de água, consumo de papel e consumo de copos plásticos, conforme representado nos Gráficos 6 e 7:

Gráfico 6 - Ações Praticadas e Implementadas de Acordo com a Comissão

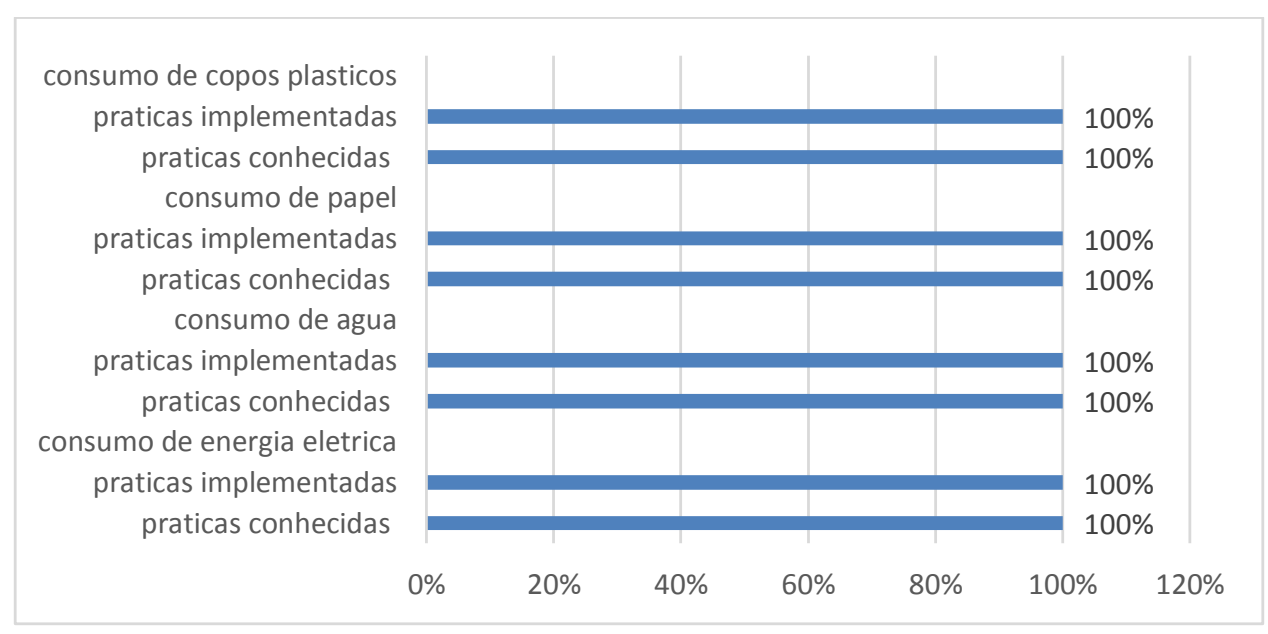

Fonte: Elaborado pela autora a partir dos dados da pesquisa 
Gráfico 7 - Ações Praticadas e Implementadas de acordo com os Servidores

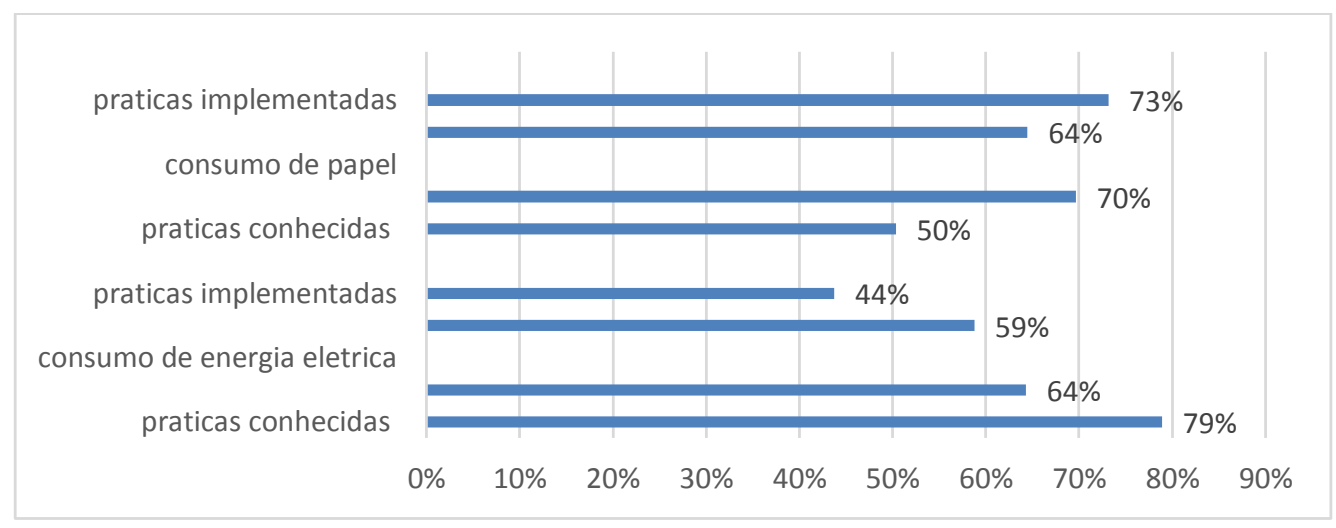

Fonte: Elaborado pela autora a partir dos dados da pesquisa

Assim, é possível extrair que para os membros do Núcleo de Gestão Socioambiental e da Comissão Gestora do PLS/TJTO, possui uma visão diferente dos servidores a respeito das práticas conhecidas e implementadas no âmbito do Tribunal, que pode ser pontuada como uma fragilidade na institucionalização da gestão sustentável, visto que o núcleo principal para a institucionalização socioambiental possui uma percepção destoante daqueles a quem deve se chegar as ações parametrizadas. Neste sentido, é preciso que a comissão tenha conhecimento do feedback de suas ações para revisão de seus atos.

A mesma sistemática de análise e discussão, foi adotada para apuração dos resultados referentes ao eixo "gestão adequada dos resíduos gerados" o que possibilitou atestar quais as práticas conhecidas e quais as implementadas no Tribunal de Justiça, para os indicadores coleta seletiva e gestão de resíduos perigosos.

A Tabela 8 demonstra os resultados a respeito da prática da coleta seletiva sob a ótica da comissão ambiental e dos servidores:

Tabela 8 - Gestão Adequada dos Resíduos Gerados - Coleta Seletiva

\begin{tabular}{l|l|l|l|l}
\hline \multicolumn{2}{c}{ PRÁTICAS - GESTÃO ADEQUADA DE RESÍDUOS GERADOS } \\
\hline \multirow{2}{*}{ Especificação } & \multicolumn{2}{c}{ Comisão } & \multicolumn{2}{c}{ Servidores } \\
\cline { 2 - 4 } & Conhecida & Implementada & Conhecida & Implementada \\
\hline
\end{tabular}




\begin{tabular}{|c|c|c|c|c|c|c|c|c|}
\hline & Sim & Não & Sim & Não & Sim & Não & Sim & Não \\
\hline $\begin{array}{l}\text { Reciclagem (de papel, papelão, } \\
\text { plásticos, cartuchos de toner) }\end{array}$ & $\begin{array}{c}8 \\
100 \% \\
\end{array}$ & 0 & $\begin{array}{l}8 \\
100 \% \\
\end{array}$ & 0 & $\begin{array}{c}9 \\
35 \% \\
\end{array}$ & $\begin{array}{l}17 \\
65 \% \\
\end{array}$ & $\begin{array}{ll}2 \\
11 \% \\
\end{array}$ & $\begin{array}{l}17 \\
89 \% \\
\end{array}$ \\
\hline $\begin{array}{l}\text { Descarte e destinação corretos } \\
\text { de materiais recicláveis e não } \\
\text { recicláveis }\end{array}$ & $\begin{array}{c}8 \\
100 \%\end{array}$ & 0 & $\begin{array}{l}8 \\
100 \%\end{array}$ & 0 & $\begin{array}{c}6 \\
26 \%\end{array}$ & $\begin{array}{l}17 \\
74 \%\end{array}$ & $\begin{array}{l}2 \\
10 \%\end{array}$ & $\begin{array}{l}18 \\
90 \%\end{array}$ \\
\hline $\begin{array}{lcr}\text { Destinação } & \text { de } & \text { material } \\
\text { reciclável às } & \text { cooperativas ou } \\
\text { associações } & \text { de } & \text { catadores } \\
\text { cadastradas } & \text { de } & \text { materiais } \\
\text { recicláveis } & \text { (coleta } & \text { seletiva } \\
\text { solidária) } & & \\
\end{array}$ & $\begin{array}{c}8 \\
100 \%\end{array}$ & 0 & $\begin{array}{l}8 \\
100 \%\end{array}$ & 0 & $\begin{array}{c}10 \\
40 \%\end{array}$ & $\begin{array}{l}15 \\
60 \%\end{array}$ & $\begin{array}{l}6 \\
30 \%\end{array}$ & $\begin{array}{l}14 \\
70 \%\end{array}$ \\
\hline $\begin{array}{l}\text { Separação adequada de } \\
\text { resíduos gerados (papel, } \\
\text { plástico, vidro, metal, comum } \\
\text { ou materiais recicláveis e não } \\
\text { recicláveis) }\end{array}$ & $\begin{array}{c}8 \\
100 \%\end{array}$ & 0 & $\begin{array}{l}8 \\
100 \%\end{array}$ & 0 & $\begin{array}{c}7 \\
26 \%\end{array}$ & $\begin{array}{l}20 \\
74 \%\end{array}$ & $\begin{array}{l}1 \\
5 \%\end{array}$ & $\begin{array}{l}18 \\
95 \%\end{array}$ \\
\hline $\begin{array}{ll}\text { Conscientização } & \text { e } \\
\text { sensibilização de } & \text { servidores e } \\
\text { colaboradores quanto à } \\
\text { destinação de resíduos e } \\
\text { aplicação da Política dos 5R's } \\
\text { (repensar, recusar, reduzir, } \\
\text { reutilizar e reciclar) }\end{array}$ & $\begin{array}{c}8 \\
100 \%\end{array}$ & 0 & $\begin{array}{l}8 \\
100 \%\end{array}$ & 0 & $\begin{array}{c}7 \\
35 \%\end{array}$ & $\begin{array}{l}13 \\
65 \%\end{array}$ & $\begin{array}{l}7 \\
37 \%\end{array}$ & $\begin{array}{l}12 \\
63 \%\end{array}$ \\
\hline
\end{tabular}

Fonte: Elaborado pela autora a partir dos dados da pesquisa

A comissão em unanimidade entendem que todos os temas abordados a respeito da coleta seletiva estão sendo conhecidos e implementados na integralidade. Fato que não condiz com a percepção dos servidores, visto que em todos os indicadores abordados na tabela 8 não são conhecidos e ou implementos no Tribunal.

O mesmo método de abordagem foi exercido para averiguação de como está sendo conhecida e implementada as ações envolvendo gestão dos resíduos perigosos para a comissão socioambiental e servidores, conforme demonstrativo apresentado na Tabela 9:

Tabela 9 - Gestão Adequada dos Resíduos Gerados - Gestão dos Resíduos Perigosos

\begin{tabular}{|c|c|c|c|c|c|c|c|c|}
\hline \multicolumn{9}{|c|}{ PRÁTICAS - GESTÃO ADEQUADA DE RESÍDUOS GERADOS } \\
\hline \multirow[t]{3}{*}{ Especificação } & \multicolumn{4}{|c|}{ Comissão } & \multicolumn{4}{|c|}{ Servidores } \\
\hline & \multicolumn{2}{|c|}{ Conhecida } & \multicolumn{2}{|c|}{ Implementada } & \multicolumn{2}{|c|}{ Conhecida } & \multicolumn{2}{|c|}{$\begin{array}{l}\text { Implementad } \\
\text { a }\end{array}$} \\
\hline & Sim & Não & Sim & Não & Sim & Não & Sim & Não \\
\hline $\begin{array}{l}\text { Descarte adequado de resíduos } \\
\text { perigosos } \\
\text { fluorescentes, pilhas, baterias) }\end{array}$ & $\begin{array}{c}8 \\
100 \%\end{array}$ & 0 & $\begin{array}{l}8 \\
100 \%\end{array}$ & 0 & $\begin{array}{c}12 \\
50 \%\end{array}$ & $\begin{array}{l}12 \\
50 \%\end{array}$ & $\begin{array}{l}10 \\
45 \%\end{array}$ & $\begin{array}{l}12 \\
55 \%\end{array}$ \\
\hline $\begin{array}{l}\text { Utilização de logística reversa } \\
\text { de resíduos perigosos } \\
\text { (lâmpadas, pilhas, baterias, } \\
\text { cartuchos e toners não } \\
\text { recicláveis) }\end{array}$ & $\begin{array}{c}8 \\
100 \%\end{array}$ & 0 & $\begin{array}{l}8 \\
100 \%\end{array}$ & 0 & $\begin{array}{c}12 \\
48 \%\end{array}$ & $\begin{array}{l}13 \\
52 \%\end{array}$ & $\begin{array}{l}9 \\
43 \%\end{array}$ & $\begin{array}{l}12 \\
57 \%\end{array}$ \\
\hline
\end{tabular}




\begin{tabular}{|c|c|c|c|c|c|c|c|c|}
\hline $\begin{array}{l}\text { Elaboração de plano de gestão } \\
\text { de resíduos }\end{array}$ & $\begin{array}{c}8 \\
100 \%\end{array}$ & 0 & $\begin{array}{l}7 \\
90 \%\end{array}$ & $\begin{array}{l}1 \\
10 \%\end{array}$ & $\begin{array}{c}6 \\
25 \%\end{array}$ & $\begin{array}{l}18 \\
75 \%\end{array}$ & $\begin{array}{l}4 \\
22 \%\end{array}$ & $\begin{array}{l}14 \\
78 \%\end{array}$ \\
\hline $\begin{array}{l}\text { Destinação adequada de lixo } \\
\text { eletrônico } \\
\text { telefones, aparelhos) }\end{array}$ & $\begin{array}{c}8 \\
100 \%\end{array}$ & 0 & $\begin{array}{l}8 \\
100 \%\end{array}$ & 0 & $\begin{array}{c}8 \\
35 \%\end{array}$ & $\begin{array}{l}15 \\
65 \%\end{array}$ & $\begin{array}{l}5 \\
29 \%\end{array}$ & $\begin{array}{l}12 \\
71 \%\end{array}$ \\
\hline
\end{tabular}

Fonte: Elaborado pela autora a partir dos dados da pesquisa

Veja que no resultado apresentando na tabela 26, para a comissão ambiental todas as práticas são conhecidas e adotas, tendo apenas um membro da comissão divergido do posicionamento ao abordar que não há a implementação da elaboração de plano de gestão de resíduos. Contudo, de acordo com a percepção apresentada pelos servidores na tabela 26, as ações não são conhecidas e nem tem conhecimento se as mesmas são implementadas.

Assim como abordado no eixo temático uso racional de recursos naturais e bens públicos, também é possível comparar as práticas conhecidas e implementadas sob a percepção da comissão ambiental e dos servidores para o eixo geração de resíduos sólidos, conforme Gráficos 8 e 9:

Gráfico 8 - Ações Praticadas e Implementadas de Acordo com a Comissão

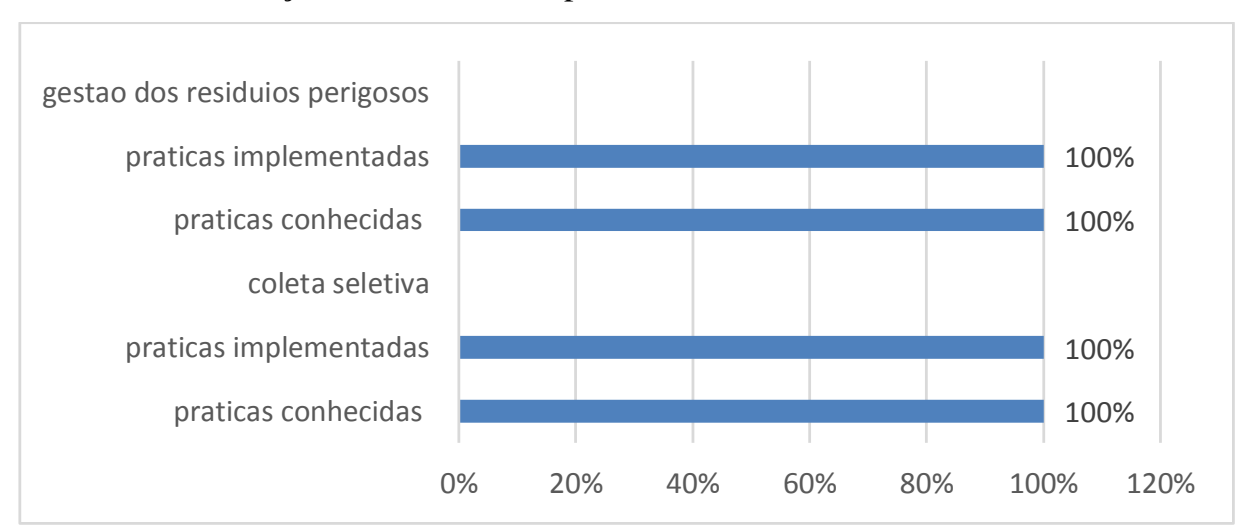

Fonte: Elaborado pela autora a partir dos dados da pesquisa

Gráfico 9 - Ações Praticadas e Implementadas de Acordo com a Comissão 


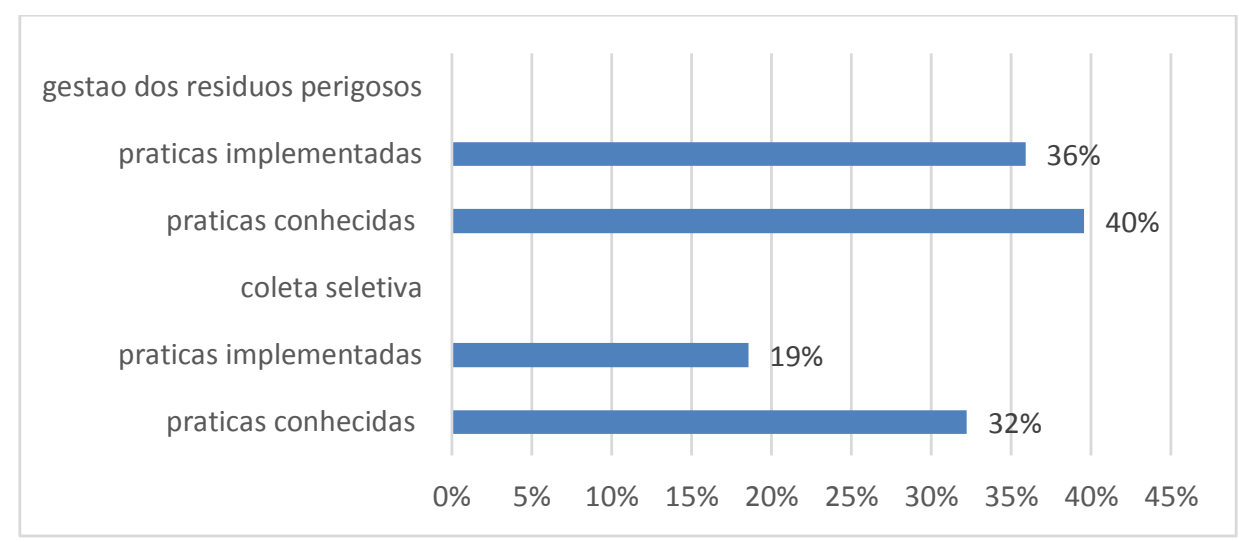

Fonte: Elaborado pela autora a partir dos dados da pesquisa

Cabe também apontar aqui que a comissão ambiental possui uma visão diferente dos servidores a respeito das práticas conhecidas e implementadas no âmbito do Tribunal que envolvem o eixo gestão adequado dos resíduos sólidos, procedendo-se a mesma análise realizado para o eixo uso racional de recursos naturais e bens púbicos, no tocante a detecção de uma fragilidade na institucionalização da gestão sustentável, sendo necessário adoção de medidas de revisão dos atos da comissão ambiental.

Os resultados revelam que é necessário planejamento, sensibilização e capacitação dos servidores, para se alcançar a maximização da efetividade de institucionalização da gestão sustentável no Tribunal de Justiça do Tocantins.

Para finalizar, buscou-se extrair dos servidores quais seriam os pontos positivos que a implantação da gestão sustentável trouxe ao Tribunal, tendo os mesmos manifestado na forma que segue (texto extraído da questão 23 do Questionário A, constante do Apêndice B):

“a) Novo pensamento por parte da equipe, noção maior sobre a preservação do meio ambiente;

b) Um primeiro passo que auxiliará nos passos seguintes;

c) Ampliação da conscientização sobre a responsabilidade ambiental que ajuda a melhorar os indicadores socioambientais;

d) O principal ponto positivo foi lançar a semente da mudança de cultura e fazer com que todas as pessoas que trabalham no Poder Judiciário entendam que práticas socioambientais é responsabilidade de todos, e não apenas dos gestores;

e) Minimizar os impactos ambientais;

f) Melhorias no desperdício de água, energia elétrica e consumo de materiais e produtos recicláveis; 
g) Redução de consumo e descarte correto;

h) As ações voluntárias de servidores e a mensuração de consumo de água, telefone, energia e combustível;

j) Economizando principalmente custeio dos recursos;

1) Melhor conscientização dos servidores, redução dos gastos e de recursos do TJTO;

m) Logística reversa, informática, qualidade de vida, semana da saúde, corrida do judiciário, judiciário na medida;

p) Melhoria de qualidade de vida, economia de recursos públicos, responsabilidade social;

q) Adoção de política de economia de energia elétrica, copo de material reciclável, economia de papel, destinação de lixo tais como: baterias velhas, etc, para o descarte correto;

r) A implantação é fundamental à sustentabilidade do empreendimento atuando de forma responsável e estratégica sobre programa educação ambiental, gestão do patrimônio, qualidade de sistema de ar e outros;

s) Redução do número de impressão com a implantação do software de gestão e contabilização de impressões, redução do consumo de copos descartáveis, uso controlado de energia elétrica e água."

Tendo dentre as respostas, manifestações que apontam o descontentamento com a implantação da gestão sustentável no Tribunal, cuja respostas foram as seguintes:
a) "Nenhum
b) Falta de continuidade
c) Quando for implantado na prática poderei responder"

Com base nas discussões apresentadas, é possível perceber que a implementação das práticas socioambientais no Tribunal ainda é apresentada de forma embrionária, que demanda um engajamento maior de todos os envolvidos. Inegável que o pouco que já foi realizado trouxe reflexos positivos nos âmbito interno do Tribunal, contudo, pelo diagnóstico realizado necessita ainda de uma maior divulgação das ações para o reconhecimento das práticas por parte dos servidores e uma maior conscientização por parte destes quanto à importância das práticas ambientais.

À luz de toda discussão realizada até o momento, abordaremos na subseção seguinte, uma análise geral de todo o processo até então conduzido, realizando um 
triangulação entre os dados alcançados com a pesquisa documental, com as informações extraídas no PLS/TJTO e seus Relatórios, com o dados obtidos a partir da aplicação dos questionários que buscou a visão da comissão ambiental e dos servidores sobre a temática.

\subsection{Discussão do Processo de Institucionalização da Gestão Socioambiental no TJTO}

A presente subseção tem como objetivo analisar as potencialidades e ou deficiências do processo de institucionalização da gestão socioambiental do TJTO sobre os mais relevantes aspectos identificados ao longo da pesquisa, considerando os dados obtidos com a análise documental, relatórios do PLS/TJTO e questionários aplicados à comissão ambiental e aos servidores.

Tomando por base as principais orientações instituídas pelo CNJ, teceremos de forma geral como ocorre o processo de institucionalização da gestão ambiental no TJTO, o modo pelo qual normatizou a temática, a efetivação das práticas e os resultados até então obtidos.

Desde 2007, por meio da Recomendação $n^{\circ}$. 11 que o CNJ indica adoção de políticas públicas "que possibilitem a formação e recuperação de um ambiente ecologicamente equilibrado, além da conscientização dos próprios servidores e jurisdicionados sobre a necessidade de efetiva proteção ao meio ambiente" (CNJ, 2012, p. 7 e 8). O que demandaria dos Tribunais a criação de comissões ambientais designadas precipuamente para o referido fim (CNJ, 2007), o que reforça que o assunto deve ser visto e tratado de forma específica por cada Tribunal.

Contudo, o Tribunal de Justiça do Estado do Tocantins, de acordo com os registros referentes às práticas ambientais adotadas em seu âmbito, tomou iniciativas neste sentido somente a partir de 2014 com a edição da Portaria $n^{\circ} .4119$ que instituiu no órgão previsões de ações estratégicas (2015-2020) para a implantação do programa A3P, cujo objetivo é a adoção de ações sustentáveis que despertem nos servidores a conscientização da necessidade de se preservar o meio ambiente, a partir da redução do combate ao desperdício no ambiente de trabalho.

Sendo que a primeira comissão ambiental no TJTO foi instalada em 2015, quando foi instituído o Núcleo de Gestão Socioambiental, já sendo fundada como uma unidade vinculada a Diretoria Geral do órgão, com caráter permanente. 
A instituição do núcleo de gestão socioambiental no TJTO, só ocorreu após a edição da Resolução nº. 201 do CNJ, que exige dos Tribunais a criação de unidades e ou núcleos socioambientais com o fim precípuo de estimular no âmbito do Tribunal "a reflexão e a mudança quanto aos padrões de compra, consumo e gestão documental dos órgãos do Poder Judiciário, bem como do corpo funcional e força de trabalho auxiliar de cada instituição" (CNJ, 2015, Art. 5).

A partir da instituição do núcleo de gestão socioambiental no TJTO, que as práticas ambientais foram desenvolvidas no Tribunal de forma efusiva, haja vista que, logo em seguida foi constituída a Comissão Gestora do Plano de Logísticas Sustentável (2015), dando start à elaboração do PLS (2016) que trouxe ações de implantação, monitoramento e avaliação da redução dos gastos dos recursos naturais no ambiente de trabalho.

Foi possível verificar que além do caráter permanente conferido ao Núcleo de Gestão Socioambiental, a sua composição é genuinamente formada por servidores efetivos, duas características que podem ser consideradas como potencialidade ao processo de institucionalização da gestação sustentável, considerando a necessidade da continuidade na prestação e execução das práticas socioambientais.

Com base nos questionários aplicados foi possível levantar que a comissão ambiental (63\%) vislumbra por parte da Instituição um comprometimento com as questões ambientais o que pode ser considerada uma potencialidade para o processo, visto que demonstra um comprometimento com a institucionalização de todo procedimento, tanto é, que logo após a imposição do $\mathrm{CNJ}$, o órgão editou normas que possibilitam a implementação da institucionalização da gestão sustentável.

No que se refere ainda à instituição da comissão socioambiental no TJTO, foi possível detectar fragilidade, quando $27 \%$ dos servidores afirmam não conhecerem as competências e 57\% conhecem parcialmente as ações desenvolvidas pela comissão o que caracteriza um limitador para a implantação da gestão sustentável. O que foi corroborado pela própria comissão ambiental, haja vista que $50 \%$ dos seus membros reconhecem que nem todos departamentos do Tribunal conhecem as ações desenvolvidas por eles.

As comissões ambientais, são comissões de suma importância para que a gestão sustentável ocorra de forma efetiva, cuja visibilidade e reconhecimento devem alcançar o grau máximo perante os servidores do Tribunal para o atingimento dos objetivos pretendidos. Deste modo é necessário realizar sensibilização e capacitação para que todos tomem conhecimento da razão pela qual foi constituída e quais ações são desenvolvidas. 
A sensibilização e a conscientização do corpo funcional do Tribunal é uma das recomendações do CNJ, o que se deu inicialmente por meio da Recomendação no ${ }^{\circ}$ 11/2007, passando a ser uma ação obrigatória com o advento da Resolução nº. 201/2015. Deste modo, o Tribunal de Justiça do Tocantins inseriu no seu PLS como eixo temático a sensibilização dos servidores, tendo estipulado como meta para o ano de 2016 a elaboração do Plano de Capacitação e para o ano de 2017 o Plano de Educação, e de acordo com os relatórios do PLS referidas metas foram devidamente cumpridas.

Muito embora noticiam a existência de planos para capacitação e educação à respeito da temática, para $38 \%$ dos membros da comissão ambiental as ações para sensibilização e capacitação dos servidores precisam melhorar, sendo que $33 \%$ dos servidores afirmam que às vezes as ações da comissão contribuem para a sensibilização da temática, $27 \%$ entendem que sempre contribuem, $27 \%$ entendem que nunca contribuem e $13 \%$ não responderam. O que denota que para $77 \%$ dos servidores as práticas precisam melhorar para que ocorra a incorporação das referidas ações.

Corroboram os índices acima apontados, o fato de que $52 \%$ dos servidores afirmaram não conhecer os temas ligados a "sustentabilidade e gestão social", práticas de sustentabilidade ambiental”, “A3P”, "PLS”, "conhecimento do uso sustentável de recursos naturais e bens públicos na Administração" e "gestão adequada de resíduos gerados".

A forma como a sensibilização está acontecendo no Tribunal demonstra uma fragilidade para a institucionalização da gestão sustentável no órgão, o que denota a necessidade do Tribunal colocar em prática o plano de capacitação e educação já elaborados, possibilitando a comunicação, conscientização, disseminação das práticas que favoreçam o processo, ou rever os métodos de conscientização o que pode ser feito por meio de divulgação de matérias com periodicidade no site do órgão, usar a ferramenta Zap Justiça e lançar informações no SEI.

Além da criação da unidade ou núcleo de gestão socioambiental no âmbito dos Tribunais o CNJ, por meio da Resolução nº 201/2015 ainda impôs que estes instituíssem o Plano de Logística Sustentável.

É por meio do PLS que é possível definir os objetivos, responsabilidades, ações, metas, prazos, monitoramento e a avaliação dos resultados, ou seja, é o instrumento que permite estabelecer e acompanhar as práticas de sustentabilidade com o fito de melhorar a eficiência dos gastos dos recursos naturais despendidos por meio das atividades executadas no órgão (CNJ, 2015, art. 10). 
Tendo em mente a importância da ferramenta, o TJTO instituiu o Plano de Logística Sustentável do Poder Judiciário do Tocantins em setembro de 2015, por meio da Portaria $n^{\circ}$. 3.943, o que representa uma potencialidade no processo de institucionalização da gestão socioambiental em seu âmbito, pois o mesmo é um instrumento vinculado ao Planejamento Estratégico do órgão, dotado de fases que permitem o desenvolvimento de uma política pública efetiva.

Para a constituição do PLS TJTO foi levado em consideração 9 etapas: constituição da comissão, realização de diagnóstico de forma intersetorial, elaboração de planos de ações, alinhamento estratégico, implementação do plano que fica à cargo dos gestores das unidades, monitoramento e avaliação pela própria comissão, revisão do plano pelo núcleo de gestão socioambiental e delimitação dos eixos temáticos.

O fato do TJTO ter seguido todas as etapas para a implementação da ferramenta ambiental pode ser considerada uma potencialidade do processo, haja vista que seguiu os passos recomendados para adoção do instrumento ambiental. Contudo, analisada as etapas de forma isolada é possível detectar potencialidades e déficits na sua implantação.

No que tange a fase de diagnóstico, a comissão ambiental informa que para implantação do PLS foi realizado diagnóstico de forma individualizada por departamento o que permite aferir uma potencialidade.

Contudo, quando questionado aos servidores a respeito da realização de diagnóstico, levantamento estatístico e disponibilização de dados, 55\% afirmaram que não foi realizado diagnóstico para a identificação dos prováveis impactos ambientais decorrentes de suas atividades, 54\% informam a realização de levantamento de dados e $50 \%$ que teria havido disponibilização da mensuração e ou levantamento dos dados, o que caracteriza fragilidade no processo de institucionalização da gestão socioambiental, visto que os servidores (diretores e chefes de divisões), não possuíam total esclarecimento quanto às práticas exercidas pela comissão.

Foi possível ainda detectar fragilidade no que se refere a implementação do plano que fica à cargo dos gestores, visto que para $63 \%$ dos membros da comissão ambiental raramente há comprometimento dos departamentos no que concerne as incorporações das práticas socioambientais, o que restou evidenciado nos resultados apresentados à respeito do PLS para os anos de 2016 e 2017, visto que houve Diretoria que deixou de apresentar informações que possibilitem a comissão realizar o monitoramento e a avaliação dos eixos, como ocorrido para a gestão de resíduos no ano de 2017. 
O Tribunal de Justiça do Tocantins cumpriu com as exigências do CNJ (art. 16 da Resolução $n^{\circ}$. 201) ao englobar em seu PLS todos os eixos temáticos requisitado na norma editada: gestão de materiais de consumo (papel, água engarrafada, copos descartáveis), Gestão de consumo (água e esgoto, energia elétrica, serviço telefonia e transmissão de dados), gestão de resíduos, serviços de limpeza, vigilância, consumo de combustível, gestão de frotas de veículos, layout, educação socioambiental, impressão de documentos e equipamentos instalados e gestão da qualidade de vida no trabalho, constituindo uma potencialidade.

Antes do rol das práticas socioambientais acima estabelecidas, as ações desenvolvidas no Tribunal ocorriam de forma esparsa sem a metodologia que permitisse aferir o seu monitoramento e possível avaliação.

Salienta-se que as escolhas dos eixos temáticos condensam em ações relacionadas ao "uso racional de recursos naturais e bens públicos" que são ações voltadas para redução ou mitigação dos impactos ambientais nas atividades administrativas, combate ao desperdício e consumo consciente e à "gestão adequada de resíduos gerados", destinação correta provenientes dos resíduos das atividades administrativas.

A comissão gestora do Plano de Logística Sustentável em cumprimento as normas estabelecidas pelo CNJ e pela própria Portaria que a instituiu, que impõe o dever de dar publicidade dos resultados obtidos para as ações planejadas, desde a implantação do PLS concede a devida publicidade aos relatórios concernentes às práticas socioambientais desenvolvidas nos anos de 2016 e 2017, o que configura uma potencialidade ao processo de institucionalização, visto que permite realizar uma avaliação e após o aperfeiçoamento das práticas socioambientais.

Além da avaliação e do monitoramento, a divulgação dos relatórios permite ainda, o acompanhamento e controle social da política pública desenvolvida pelo Poder Judiciário, possibilitando ampliação do acesso à informação a todas as comarcas do Estado e demais órgãos, o que serve de esteio para disseminação das boas práticas ambientais, podendo servir de parâmetros, além de ser a forma mais transparente de prestação de contas aos jurisdicionados quanto à contribuição do judiciário à sustentabilidade.

Aferiu-se por meio dos questionários que existe canal de comunicação estabelecido com a população para reclamações, críticas e ou sugestões o que pode ocorrer por meio de envio de mensagens para o e-mail do núcleo de gestão socioambiental, ouvidoria e ou controladoria do órgão, o que parece ser insuficiente, visto que tais métodos 
não são divulgados e a ouvidoria e controladoria não seria um canal direto de comunicação com a comissão ambiental.

Embora, exista a comunicação por meio dos canais descritos acima, o Tribunal poderia potencializar a comunicação com a população e prestar contas de suas ações se operacionalizasse uma página eletrônica vinculada ao site do TJTO, voltada especificamente para a temática, onde poderiam divulgar as ações, as normatizações, documentos de implantação da comissão ambiental, manuais, além dos relatórios das atividades socioambientais. Servindo também como um canal para sensibilização e educação dos servidores e da população em geral.

Dentre as práticas socioambientais realizadas é possível destacar a redução de papel, copos descartáveis, águas engarrafadas que superou ou atingiu as metas impostas para os anos de 2016 e 2017, o que pode ser considerado como uma ação dotada de potencialidade, podendo ser copiada por outros órgãos, face a incrementação da adoção do uso de processos digitais e controle de impressões por meio de ilhas o que possibilitou a diminuição de papel, fornecimento de copos de fibra de coco aos servidores diminuindo o uso copos descartáveis e adoção de bebedouros nos corredores do prédio diminuindo o consumo de águas engarrafadas.

A sensibilização e a conscientização do corpo funcional do Tribunal é uma das recomendações do CNJ, o que se deu inicialmente por meio da Recomendação nº 11/2007, passando a ser uma ação obrigatória com o advento da Resolução ${ }^{\circ}$. 201/2015. Deste modo, o Tribunal de Justiça do Tocantins inseriu no seu PLS como eixo temático a sensibilização dos servidores, tendo estipulado como meta para o ano de 2016 a elaboração do Plano de Capacitação e para o ano de 2017 o Plano de Educação, cujas metas foram devidamente cumpridas.

Muito embora o PLS do TJTO noticia a existência de planos para capacitação e educação à respeito da temática, para 38\% dos membros da comissão ambiental as ações para sensibilização e capacitação dos servidores precisam melhorar, sendo que $33 \%$ dos servidores afirmam que às vezes as ações da comissão contribuem para a sensibilização da temática, e para $68 \%$ dos servidores as práticas precisam melhorar para que ocorra a incorporação das referidas ações.

Corrobora os índices acima apontado o fato de 52\% dos temas ligados a "sustentabilidade e gestão social", práticas de sustentabilidade ambiental", “A3P", "PLS", "conhecimento do uso sustentável de recursos naturais e bens públicos na Administração" 
e "gestão adequada de resíduos gerados" não serem conhecidos pelos servidores. Os resultados indicam que as normas do CNJ e TJTO que instituem a gestão sustentável são de conhecimento de poucos servidores, visto que $25 \%$ não assinalaram nenhuma alternativa e ou declararam pouco conhecimento.

A forma como a sensibilização está acontecendo no Tribunal demonstra uma fragilidade para a institucionalização da gestão sustentável no órgão, o que denota a necessidade do Tribunal colocar em prática o plano de capacitação e educação elaborados para tal, possibilitando a comunicação, conscientização, disseminação das práticas que favoreçam o processo, ou rever os métodos de conscientização por meio de métodos simples, como: matérias divulgadas no site do órgão, uso de ferramenta como Zap Justiça, informações lançadas no SEI.

As ações voltadas para a gestão dos serviços de limpeza, consumo de combustível e de frota de veículos não conseguiram cumprir as metas estabelecidas para os anos de 2016 e 2017, apontando uma fragilidade no que diz respeitos a essas temáticas, devendo as metas serem revistas para andar em consonância com a proposta de diminuição dos gastos e consumo, conforme demandado no PLS.

Por meio dos questionários aplicados aos servidores foi possível identificar que $79 \%$ das práticas relacionadas ao consumo de energia elétrica são conhecidas e 64\% implementadas, que 59\% das práticas relacionadas a consumo de água são conhecidas e 44\% implementadas, que $50 \%$ das práticas relacionadas com consumo de papel são conhecidas e $70 \%$ implementadas e que $64 \%$ das práticas afetas a consumo de copos plásticos são conhecidas e $73 \%$ implementadas.

Deste modo é possível afirmar ainda que faltam aos servidores um conhecimento maior quanto a implementação das práticas socioambientais relacionados ao uso dos recursos naturais, o que denota a necessidade de potencializar a educação e sensibilização dos servidores.

No que se refere às práticas relacionadas à gestão de resíduos gerados com base nos dados obtidos com os questionários que apontam que para os servidores $32 \%$ das práticas concernentes à coleta seletiva são conhecidas e 19\% implementadas e que $40 \%$ das práticas de gestão de resíduos perigosos são conhecidos e $36 \%$ implementados, que comparado com o Relatório do PLS para o ano de 2016 ainda não foi implantada a coleta seletiva, cuja previsão é até 2020 e que a Diretoria responsável não forneceu dados para o ano de 2017. 
Outra fragilidade detectada com base nos dados esculpidos nos Relatórios, foi o fato de que Diretorias responsáveis pela implementação das ações e monitoramento das ações deixaram de fornecer dados que pudessem auxiliar na avaliação dos resultados, possibilitando o aperfeiçoamento das ações, impossibilitando assim, aferir os graus de execução das ações.

Deve o Tribunal adotar medidas internas para execução das práticas relacionadas ao eixo temático geração de resíduos sólidos para alcançar os objetivos propostos, o que pode ser realizado por meio de edição de Instrução Normativa e Termo de Habilitação para a adequada coleta de resíduos descartáveis, celebração de contratos com catadores de materiais recicláveis e sensibilização e capacitação de servidores.

Restou detectado com base nos dados obtidos por meio da aplicação dos questionários que falta sensibilização e conhecimento por parte do corpo funcional sobre os assuntos relacionados à gestão socioambiental, ações, programas e metas estabelecidas (item 4.3.2), devendo o Tribunal rever o método de conscientização que vem utilizando, promover capacitação aos servidores, divulgar matérias no site do órgão, utilizar-se das ferramentas disponíveis, como o Zap Justiça e o SEI, para prestar informações quanto aos assuntos necessários à implantação da gestão sustentável.

Para o fortalecimento da relação da comissão ambiental com a Instituição é necessário engajamento maior por partes dos agentes envolvidos, Administração, servidores e comissão, o que poderá ocorrer por meio de divulgação, capacitação e comunicação institucional sobre a temática, devendo haver uma maior comunicação entre os mesmos.

Ficou consignado ainda (dados obtidos no item 4.3.3) que o conhecimento por parte dos servidores de como se operacionaliza a institucionalização da gestão socioambiental no Tribunal não atinge a todos, o que denota a necessidade de revisão dos métodos utilizados pela comissão ambiental devendo buscar meios para maior divulgação e planejamentos de suas ações.

No que se refere à sensibilização e capacitação socioambiental, temática crucial para boa execução e continuidade das ações ambientais na rotina das atividades do Tribunal, constatou-se (com base nos dados obtidos no item 4.3.4) que a sensibilização deve ocorrer de forma mais intensa e maciça, o que pode ser realizado por meio de confecção de manuais, parceria intensa com a ESMAT para disponibilização de cursos, palestras, presenciais e ou à distância, estabelecendo no calendário de suas atividades a 
semana do meio ambiente, tendo vista que, a capacitação e sensibilização deve ocorrer de forma contínua.

Por fim, tem-se ainda, que as ações relacionadas às práticas socioambientais que estão sendo incorporadas no Tribunal (item 4.3.5), precisam de um olhar especial por parte da comissão, visto que nem todas as práticas estão sendo conhecidas pelos servidores, muito menos chegam ao seu conhecimento que estão sendo implementadas, para o aumento deste índice é necessário uma revisão dos atos da comissão para que as práticas passem a ser efetivamente conhecidas e implementadas.

Assim, por meio da Quadro 18 é possível retratar as principais potencialidades e deficiências identificadas na análise da gestão sustentável no Tribunal de Justiça do Tocantins.

Quadro 18 - Potencialidades e Deficiências na Gestão Sustentável TJTO

\begin{tabular}{|c|c|}
\hline POTENCIALIDADES & 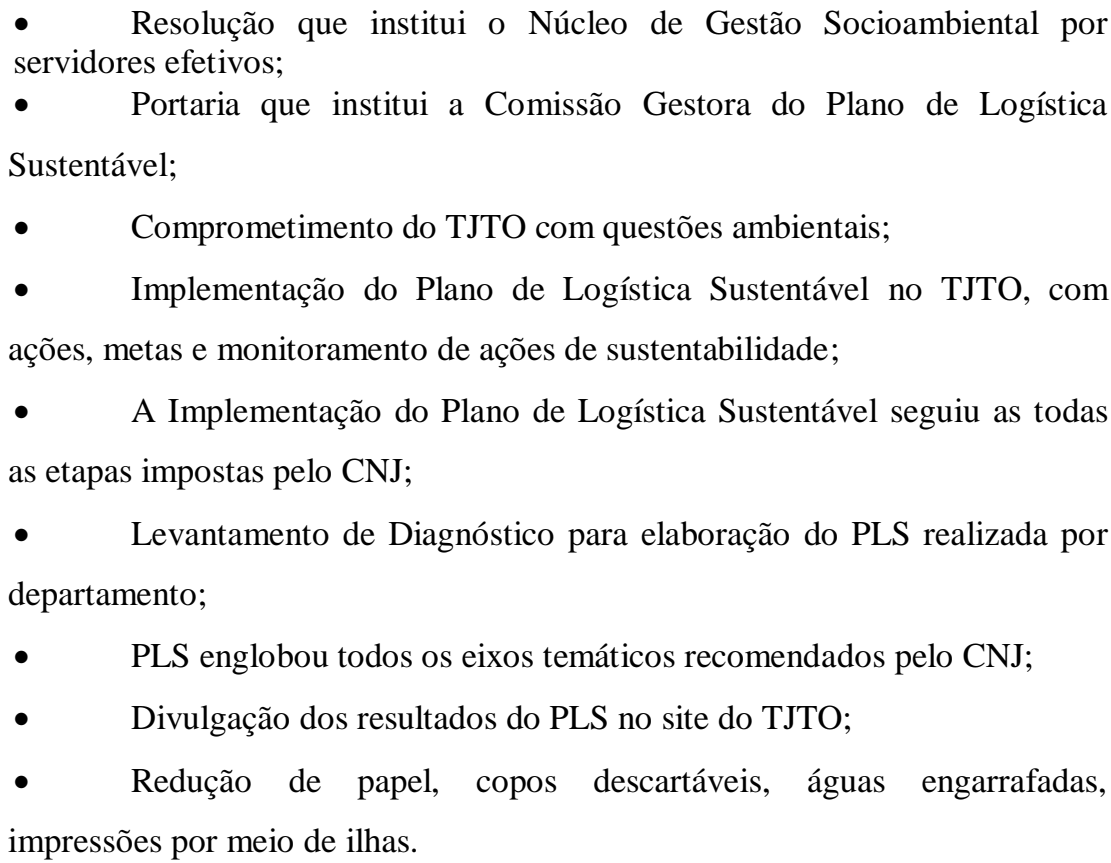 \\
\hline LIMITAÇÕES / & $\begin{array}{l}\text { - Servidores não conhecem competências da Comissão Ambiental; } \\
\text { - } \quad \text { Servidores não possuem esclarecimentos quanto às práticas exercidas } \\
\text { pela comissão; } \\
\text { - } \quad \text { Falta de comprometimento dos gestores para implantar planos de ação } \\
\text { do PLS; } \\
\text { - } \quad \text { Falta comunicação com a população; } \\
\text { - } \quad \text { Forma como a sensibilização e capacitação está acontecendo no TJTO } \\
\text { não está alcançando todos os servidores; } \\
\text { - } \quad \text { Ações voltadas para serviço de limpeza, consumo de combustível e } \\
\text { frota de veículos, não atingiu as metas impostas; } \\
\text { - } \quad \text { Falta conhecimento quanto à implementação das práticas } \\
\text { socioambientais relacionadas ao uso dos recursos naturais; } \\
\text { - } \quad \text { Não fornecimento de dados que auxiliem no monitoramento das ações }\end{array}$ \\
\hline
\end{tabular}


Elaborado pela Autora

pela Diretoria responsável.

Neste sentido, a seção a seguir propõe sugestões acerca de ações que podem ser desenvolvidas para potencializar a implementação da gestão socioambiental do TJTO.

\subsection{Propostas de Melhorias para a Gestão Socioambiental no Tribunal de Justiça do Tocantins}

Por fim, pretende com esta subseção apresentar ações que possam contribuir para a gestão socioambiental do Tribunal de Justiça do Tocantins, o que será feito a partir do diagnóstico obtido com as análises do rol de documentos de instituição da sustentabilidade, diretrizes do planejamento estratégico, PLS e seus relatórios, bem como questionários aplicados aos servidores do órgão.

As sugestões que seguem abaixo foram construídas a partir das deficiências/limitações/fragilidades detectadas durante a análise da institucionalização da gestão socioambiental no TJTO:

- Instituir o calendário socioambiental no Tribunal de Justiça do Estado do Tocantins, concedendo a devida publicidade aos servidores;

A instituição de um calendário das ações ligadas principalmente ao eixo temático capacitação e sensibilização e qualidade de vida no trabalho contribuirá com o monitoramento das metas estabelecidas para as práticas socioambientais.

- $\quad$ Promover em parceria com a Escola Superior de Magistratura ESMAT cursos e ou palestras ao longo do ano.

Importante que as palestras e ou cursos sejam periódicos e contínuos ocorrendo pelo menos de 2 em 2 meses, para ser abordado assuntos relacionados a cada eixo temático de forma individualizada ou agrupado por afinidade, as normas que envolvem a sustentabilidade, ações e programas ligados à temática.

- Desenvolver em parceria com a ESMAT Manual da Institucionalização da Gestão Socioambiental para exposição aos servidores e jurisdicionados.

O manual é uma maneira de trazer conhecimento aos servidores e jurisdicionados com informações a respeito das normas ligadas à sustentabilidade, 
instituição e papel do Núcleo de Gestão Socioambiental do TJTO e Comissão Gestora do PLS, abordar sobre A3P, PLS e seus resultados, dando publicidade por meio de disponibilização no site do TJTO, enviando por e-mail aos servidores e se possível realizar a impressão gráfica.

- $\quad$ Promover junto com a Diretoria da Comunicação Social, vídeos curtos com informações sobre a temática.

Os vídeos podem ser disponibilizados no site do TJTO, estabelecendo um canal com a sociedade e enviados aos servidores.

- Criar por meio da Diretoria de Informática e Tecnologia página própria do Núcleo de Gestão Socioambiental ou link próprio no site do TJTO;

Uma página exclusiva para o Núcleo de Gestão Socioambiental na rede permitirá condensar informações, dar publicidade dos atos, veicular os vídeos, expor o manual, dentre outras possibilidades.

- Instituir por meio de Resolução, a Semana Integrada do Meio Ambiente, a ser promovida pelo Núcleo de Gestão Socioambiental em parceria com a Escola Superior da Magistratura, com o objetivo de promover sensibilização/conscientização dos servidores e jurisdicionados a respeito de assuntos ligados à sustentabilidade, por meio de ações como: stand na sede do Tribunal de Justiça chamando a atenção de todos para a temática com entrega de material que tragam esclarecimento/notícias sobre o assunto, palestras/cursos, notícias/vídeos temáticos enviadas por e-mail, ferramenta SEI e Zap Justiça. O objetivo deve ser o envolvimento de todo o Tribunal nas ações desenvolvidas, chamando a atenção para a temática.

Sugere-se que a intensificação das ações em uma semana do ano, coincida com a semana da publicação dos relatórios do PLS possibilitando divulgar e dar ênfase aos resultados obtidos, o que permitirá o processo contínuo referente à sensibilização.

- Desenvolver campanhas que auxiliam na diminuição dos gastos com energia elétrica, água, combustível, copo descartáveis.

Orientações adequadas que promovam a reafirmação de políticas de mudanças de hábitos relacionadas às ações para redução do consumo, através de banners, avisos, para o uso correto do bem natural do material utilizado.

- $\quad$ Editar Instrução Normativa que regulamente o descarte de resíduos recicláveis e orgânicos no âmbito do TJTO; 
Estabelecer as normas procedimentais para a separação e descarte dos resíduos e a forma da sua coleta. Como parâmetro indicamos a IN n ${ }^{\circ}$. 11/2018 do TRE/PR.

- Celebrar Termo de Cooperação Técnica com entidades que realizam o reaproveitamento de materiais recicláveis;

As parceiras com os catadores de materiais recicláveis possibilita a destinação correta dos resíduos gerados, visando à diminuição da produção residual.

- Instituir por meio de Resolução a Política Institucional da Sustentabilidade do TJTO, visando o desenvolvimento sustentável da Instituição;

Com a instituição da resolução a política de sustentabilidade passa a ser de observância obrigatória por todos os servidores, visto que será instituída a aplicação do normativo aos diversos processos de trabalho, projetos e planos de ação do Tribunal. Recomendamos como parâmetro a Resolução nº 807/2018 do TRE/PR. 


\section{CONSIDERAÇÕES FINAIS}

O mau uso dos recursos naturais despertou na sociedade internacional preocupação que demandou diversas mobilizações e ações visando conscientização, comprometimento e mudanças de hábitos da sociedade civil e poder público com o objetivo de minimizar os impactos causados à natureza.

Imbuído quanto aos compromissos assumidos, da responsabilidade social e do seu papel preponderante quanto aos assuntos relacionados ao desenvolvimento sustentável, o Estado desenvolveu políticas públicas que possibilitassem a preservação do meio ambiente, por meio de normas e disseminação de programas que devem ser observado por todos.

O Poder Judiciário investido das características e poderes inerentes à Administração Pública não se furtando das obrigações impostas pelo Estado, implementou mecanismos e ferramentas a serem seguidos por todos os Tribunais do país para o efetivo cumprimento das exigências voltadas para as atividades sustentáveis no Poder Judiciário.

Deste modo, pretendeu-se com esta pesquisa analisar o processo de institucionalização da gestão socioambiental no Tribunal de Justiça do Tocantins, para isso buscou-se caracterizar os instrumentos da gestão socioambiental do órgão, identificar a percepção dos servidores sobre a institucionalização da gestão socioambiental e detectar as potencialidades e deficiências do processo, o que se fez por meio de pesquisa bibliográfica, em busca de reflexões conceituais concernentes à sustentabilidade, análise documental dos instrumentos normativos editados sobre o tema e aplicação de questionários à comissão ambiental e servidores que exercem cargos de diretores e chefes de divisão das Diretorias do Tribunal.

Com base nos dados colhidos por meio da análise bibliográfica, documental e questionários, foi possível realizar análise das informações coletadas proporcionando as discussões e os resultados em face das características identificadas na sistematização do processo de institucionalização da gestão socioambiental no TJTO, o que resultou em sugestões de melhorias para o fortalecimento do processo.

Verificou-se que as normas impostas para o cumprimento de políticas públicas voltadas para a sustentabilidade possui um viés essencial para adoção das práticas socioambientais. O Tribunal de Justiça do Tocantins, logo após a edição da Resolução $n^{\circ}$. 201/2015 do CNJ editou normas para a instituição do núcleo de gestão socioambiental 
(Resolução $n^{\circ}$. 22/2015) e comissão para implantação e gestão do Plano de Logísticas Sustentável (Portaria nº 3943/2015), composta por servidores efetivos, contemplando a necessidade de instrumentos regulatórios para o processo de institucionalização da gestão socioambiental.

A implantação do Plano de Logística Sustentável no TJTO é instrumento fundamental para adoção de práticas socioambientais, visto que se apresenta como um instrumento de comando e controle, onde se é elaborado indicadores e estratégias no qual se estabelecem metas a serem cumpridas para minimização dos impactos ambientais, cujos resultados são apresentados anualmente por meio de relatórios divulgados no sítio do Tribunal.

A instituição das comissões socioambientais e implantação do PLS são instrumentos essenciais para a operacionalização e efetivação do processo de institucionalização da gestão socioambiental no TJTO, portanto, uma potencialidade no processo, visto que demonstra o comprometimento do órgão com a instituição das práticas socioambientais em suas atividades.

Contudo, verificou-se a necessidade de dar uma maior visibilidade às atribuições, competências e ações desenvolvidas pelas comissões socioambiental do órgão, visto que ficou registado por meio dos questionários insuficiência de conhecimento pelos servidores quanto ao seu papel, o que demanda uma mobilização no sentido de conferir uma maior divulgação por meio de sensibilização e capacitação dos servidores.

Ademais, sensibilização e capacitação são principais instrumentos para que a condução do processo de institucionalização da gestão sustentável no TJTO seja efetiva, visto que com base na análise dos dados dos questionários, verificou-se LIMITAÇÕES no tocante aos temas "conhecimento da temática e legislação socioambiental", "sensibilização e capacitação ambiental" e "práticas socioambientais".

O conhecimento dos servidores referente ao tema e as normas é essencial para a efetivação das práticas socioambientais, neste sentido, averiguou-se que falta ao órgão o uso das ferramentas adequadas para que as informações cheguem aos servidores, visto que as mesmas devem ocorrer de forma mais efusiva oportunizando acessibilidade a todos os envolvidos.

Neste mister, a sensibilização e capacitação é um limitador ao processo de institucionalização, o que demanda iniciativas de ações voltadas para este fim, o que entendemos que podem ser minimizadas por meio de ferramentas já utilizadas pelo 
Tribunal e parcerias com a Escola Superior de Magistratura, Diretoria Tecnologia e Informação e de Assessoria de Comunicação, para realização de cursos, palestras, confecção de manuais, edição de vídeos, informativos disparados aos servidores, criação de página eletrônica própria, permitindo uma polarização da conscientização sobre os hábitos que precisam ser desenvolvidos no órgão, chegando-se até à sociedade cumprindose assim seu papel social perante os jurisdicionados.

No tocante a análise das práticas socioambientais, foi possível detectar a existência de eixos temáticos apontados no PLS do órgão, voltadas para o "uso racional de recursos naturais e bens públicos" e a "gestão adequada de resíduos gerados", contudo, restou detectado a necessidade de conferir maior conhecimento sobre as práticas desenvolvidas para que sua implementação ocorra de forma efusiva, devendo ainda se pensar em edição de normas voltadas para o uso correto dos descartes de bens recicláveis e orgânicos, além da política de sustentabilidade para o fortalecimento do processo.

Por fim, constatou-se ainda, a necessidade da existência de um canal disponível e de acesso aos jurisdicionados que levem informações referentes às práticas socioambientais para reclamação, sugestões e críticas, além do conhecimento a respeito das ações desenvolvidas pelo Tribunal e consequente sensibilização da própria sociedade civil, visto que a intenção de toda esta mobilização é replicar as práticas socioambientais nas atividades da Administração Púbica que possam ser levadas para a vida e cotidiano de cada servidores, disseminando as ações em toda a sociedade.

Diante do exposto, é possível afirmar que o processo de institucionalização da gestão sustentável no TJTO existe e está em andamento, o que demanda mudanças de estratégias e condutas para conferir maior amplitude e efetivação do processo e ou trabalhar nas potencialidades identificadas, possibilitando maior repercussão no âmbito da Administração Pública, contribuindo com a gestão sustentável não apenas do TJTO como também em outros órgãos que poderão pautar-se de suas ações para parametrizar e disseminar a gestão e consciência socioambiental.

Para a realização desta dissertação foram encontradas algumas limitações. Dentre os entraves encontrados, têm a aplicação dos questionários aos diretores e chefes de divisão das diretorias e não a todos os servidores lotados no TJ; a análise das práticas socioambientais restringiu-se a dois eixos temáticos "uso racional de recursos naturais e bens públicos" e "gestão adequada dos resíduos gerados", a pesquisa não se deteve às 
análises da aferição das práticas socioambientais in loco utilizando-se dos dados apresentados nos relatórios do PLS.

Portanto, não se buscou com esta pesquisa esgotar todas as possibilidades acerca das melhorias que possam ser implementadas ao processo de institucionalização da gestão sustentável no TJTO, o que poderão ser desenvolvidas com outras pesquisas que busquem ampliar a gestão sustentável às demais comarcas do Estado, realizando uma abordagem de todo o processo no Tribunal de Justiça do Estado do Tocantins, não apenas na sede do Tribunal.

Assim, a pesquisa aqui proposta, pode ser aprofundada a partir de pesquisas futuras, com ampliação das temáticas abordadas e através de novas discussões que surgirem sobre a temática.

Espera-se, que o trabalho possa contribuir com a Administração Pública como um todo, disseminando a conscientização de seu papel na construção de uma sociedade com pensamentos voltados para o tripé da sustentabilidade: ecologicamente equilibrado, economicamente viável e socialmente justo, conferindo maior qualidade de vida as presentes e futuras gerações de forma que o Desenvolvimento Sustentável se torne realidade para a sociedade. 


\section{REFERÊNCIAS}

BARBIERI, J. C. Gestão ambiental empresarial: conceitos, modelos e instrumentos. $2^{\text {a }}$ edição. São Paulo: Saraiva, 2007.

BARATA, Martha Macedo de Lima, KLIGERMAN, Débora Cynamon, MINAYO, Carlos Gomes. A gestão Ambiental no Setor Público: uma questão de relevância social e econômica. Ciência \& Saúde Coletiva, vol. 12, n. 1, p. 165-170, 2007.

BARDIN, Laurence. Análise de Conteúdo. $1^{\text {a }}$ ed. São Paulo: Edições 70 Brasil, 2011. 280 p.

BARKI, Teresa Villac Pinheiro. Licitações e Contratações Públicas Sustentáveis. $1^{\mathrm{a}}$.ed. Belo Horizonte: Fórum, 2011.298 p.

BELLEN, Hans Michel Van. Indicadores de Sustentabilidade: uma análise comparativa. $2^{\mathrm{a}}$. ed. Rio de Janeiro: Editora FGV, 2006. 253p.

BERTÉ, Rodrigo. Gestão socioambiental no Brasil. 1ª ed. São Paulo: Saraiva, 2009. 299 p.

BEUREN, Ilse Maria. Como elaborar trabalhos monográficos em Contabilidade: teoria e prática. $3^{\mathrm{a}}$. ed. São Paulo: Atlas, 2009. 195 p.

BLIACHERIS, Marcos Weiss. Licitações Sustentáveis: política pública. Revista Direito Administrativo e Constitucional, Curitiba, número 13, volume 51, 2013.

BRASIL. Lei n. 12.187/2009. Institui a Política Nacional sobre Mudanças do Clima PNMC e dá outras providências. DOU de 30/12/2009. Edição extra. Disponível em: <http://www.planalto.gov.br/ccivil_03/_Ato2007-2010/2009/Lei/L12187.htm>. Acesso em: $1^{\circ}$ dez. 2017.

Lei n. 12.305/2010. Institui a Política Nacional de Resíduos Sólidos; altera a Lei no 9.605, de 12 de fevereiro de 1998; e dá outras providências. DOU de 03/08/2010. Disponível em: <http://www.planalto.gov.br/ccivil_03/_Ato2007

2010/2010/Lei/L12305.htm>. Acesso em: 25 nov. 2017.

Lei n. 6.938/1981. Dispõe sobre a Política Nacional do Meio Ambiente, seus fins e mecanismos de formulação e aplicação, e dá outras providências. DOU de 02/09/1981. Disponível em: <http://www.planalto.gov.br/ccivil_03/Leis/L6938.htm>. Acesso em: 28 nov. 2017.

Lei n. 9.795/1999. Dispõe sobre a educação ambiental, institui a Política Nacional de Educação Ambiental e dá outras providências. DOU de 28/04/1999. Disponível em: <http://www.planalto.gov.br/ccivil_03/Leis/L9795.htm>. Acesso em: 08 nov. 2017.

.Decreto $\mathbf{n}^{\mathbf{0}}$ 7.746, de 05 de junho de 2012. Regulamenta o art. $3^{\circ}$ da Lei no 8.666, de 21 de junho de 1993, para estabelecer critérios, práticas e diretrizes para a promoção do desenvolvimento nacional sustentável nas contratações realizadas pela administração 
pública federal, e institui a Comissão Interministerial de Sustentabilidade na Administração Pública - CISAP. Disponível em:<http://www.planalto.gov.br/ccivil_03/_ato2011-2014/2012/decreto/d7746.htm>. Acesso em: 04 jan. 2018.

Instrução Normativa $\mathbf{n}^{0}$ 10, de 12 de novembro de 2012. Secretária de Logística e Tecnologia da Informação do Ministério do Planejamento, Orçamento e Gestão. Estabelece regras para elaboração dos Planos de Gestão de Logística Sustentável de que trata o art. 16, do Decreto n ${ }^{\circ}$ 7.746, de 5 de junho de 2012, e dá outras providências. Disponível em:<http://www.lex.com.br/legis_23960118_INSTRUCAO_NORMATIVA_N_10_DE_1 2_>. Acesso em: 03 jan. 2018.

. Ministério do Meio Ambiente (MMA). A3P - Agenda Ambiental na Administração Pública. $5^{\text {a }}$ ed. Brasília, DF, 2009. Disponível em: $<$ http://www.ministeriodomeioambiente.gov.br/images/arquivo/80063/cartilha\%20complet a\% 20A3P_.pdf> Acesso em: 04 jan. 2018.

Ministério do Meio Ambiente. Histórico Institucional. Disponível em:

<http://www.mma.gov.br/o-ministerio/historico-institucional> acesso em: 04 jan. 2018.

Ministério do Meio Ambiente. Agenda 21. Disponível:

<http://www.mma.gov.br/responsabilidadesocioambiental/agenda-21> Acesso em: 19 dez. 2017.

Ministério Meio Ambiente. Plano de Implementação da Cúpula Mundial sobre Desenvolvimento Sustentável. Disponível em:

<http://www.mma.gov.br/port/sdi/ea/documentos/convs/plano_joanesburgo.pdf > Acesso em 12 de janeiro de 2018.

BRITO, Priscila Costa Ferreira. Aspecto da Gestão Pública Ambiental na Justiça Eleitoral. 2012.121 p. Dissertação Mestrado em Direito, Relações Internacionais e Desenvolvimento pela PUC/GO, Goiânia, 2012.

BURSZTYN, M. A difícil sustentabilidade: política energética e conflitos ambientais. Rio de Janeiro: Garamond, 2006.

BUCCI, Maria Paula Dallari. Políticas Públicas, reflexões sobre o conceito jurídico. São Paulo: Saraiva, 2006, 310 p.

\section{CONSELHO NACIONAL DE JUSTIÇA. $1^{\circ}$ Balanço Socioambiental do Poder Judiciário.}

Disponívelem<http://www.cnj.jus.br/files/conteudo/arquivo/2017/10/c8731235bf90f4ed2a 10162e6c14436b.pdf>. Acesso em 08 jan. 2018.

Recomendação n. 27, de 16 de dezembro de 2009. Recomenda aos Tribunais que adotem medidas para remoção de barreiras físicas, arquitetônicas, de comunicação e atitudinais de modo a promover o amplo e irrestrito acesso de pessoas com deficiência às 
suas dependências. Disponível em: <http://www.cnj.jus.br/atosnormativos?documento=873>. Acesso em 08 jan. 2018.

Relatório do Programa de Gestão Socioambiental do CNJ 2010. Traça o panorama da sustentabilidade nos Tribunais brasileiros. Disponível em: <http://www.cnj.jus.br/programas-e-acoes/pj-gestao-socioambiental/relatorios>. Acesso em 08 jan. 2018.

Resolução n. 114, de 20 de abril de 2010. Dispõe sobre o planejamento, execução e monitoramento de obras do Poder Judiciário.

Disponívelem: <http://www.cnj.jus.br/images/stories/docs_cnj/resolucao/rescnj_114.pdf >. Acesso em 09 jan. 2018.

Resolução n. 198, de $1^{\circ}$ de julho de 2014. Dispõe sobre o planejamento e a Gestão Estratégica no âmbito do Poder Judiciário. Disponível em: <http://www.cnj.jus.br/busca-atos-adm?documento=2733>. Acesso em 09 jan. 2018.

Resolução n. 201, de 3 de março de 2015. Dispõe sobre a criação e competências das unidades ou núcleos socioambientais nos órgãos e conselhos do Poder Judiciário e implantação do respectivo Plano de Logística Sustentável (PLS-PJ). Disponível em: <http://www.cnj.jus.br/busca-atos-adm?documento=2795>. Acesso em 10 jan. 2018.

Recomendação n. 11, de 22 de maio de 2007. Recomenda aos Tribunais que adotem políticas públicas visando à formação e recuperação de um ambiente ecologicamente equilibrado. Disponível em: 〈http://www.cnj.jus.br/atosnormativos?documento=867>. Acesso em 08 jan. 2018.

DPJ - Departamento de Pesquisas Judiciárias. Gestão Socioambiental. Disponível em: <http://www.cnj.jus.br/programas-e-acoes/pj-gestao-socioambiental>. Acesso em: 10 jan. 2018.

Indicadores Socioambientais do Poder Judiciário, 2012. Traça o panorama da sustentabilidade nos Tribunais brasileiros. Disponível em: http://www.cnj.jus.br/images/pesquisas-judiciarias/GestaoSocioambiental/Relatorios/impresso_rio20.pdf. Acesso em 10 jan. 2018.

CERQUEIRA FILHO, G. A questão social no Brasil: crítica do discurso político. Rio de Janeiro: Civilização Brasileira, 2004.

CHIZZOTTI, Antônio. Pesquisa Qualitativa em Ciências Humanas e Sociais. $6^{\mathrm{a}}$ ed. Petrópolis: Vozes, 2014, 144 p.

CZAPSKI, Silvia. A implantação da educação ambiental no Brasil. Coordenação de Educação Ambiental da Educação e do Desporto. Brasília: 1998. Disponível em <http://www.dominiopublico.gov.br/pesquisa/PesquisaObraForm.jsp>. Acesso em 02 nov. 2017. 
DAGNINO, Renato. Metodologia de Análise de Políticas Públicos. $1^{\text {a }}$ ed. Gestão Estratégica da Inovação: metodologia para análise e implementação. Taubaté. Cabral Universitária, 2002. 232 p.

DIAS, Genebaldo Freire. Educação Ambiental Princípios e Práticas. 9a ed. São Paulo. Editora Gaia, 2008. 398 p.

DYE, Thomas D. Mapeamento dos modelos de análise de políticas públicas. In: HEIDERMAN, Francisco G; SALIM, José Francisco. Políticas Públicas e Desenvolvimento: Bases Epistemológicas e Modelos de Análise. Brasília: Editora UnB, 2009.

FLORIANO, Eduardo Pagel. Políticas de gestão ambiental. $3^{\text {a }}$ ed. Santa Maria: UFSMDCF. 2007. 111p.

GIL, Antônio Carlos. Métodos e técnicas de pesquisa social. $4^{\mathrm{a}}$ ed. São Paulo: Atlas. 2017. $424 \mathrm{p}$.

GOODE, Willian; HATT, Paul. Métodos em pesquisa social. $6^{a}$ ed. São Paulo: Atlas, 2008. $216 \mathrm{p}$.

GODY, Arilda, Schimidt. A pesquisa qualitativa e sua utilização em administração de empresas. Revista de Administração de Empresas, v.3, n.2, p. 7-10, 1995.

GUIMARÃES, Roberto Pereira; FONTOURA, Yuna Sousa dos Reis da. Muito Ruído e Poucas Vozes: Os Discursos na Rio+20 e a Governança Global para o Desenvolvimento Sustentável. Ideias Unicamp, v. 3, n. 2, p. 7-10, 2012.

GIASSON, Felipe; APPUGLIESE, Gabriela Alem; BETIOL Luciana; Dinato Ricardo. Compras sustentáveis pela inovação e por uma economia verde inclusiva. São Paulo: ICLEI, 2015, 58 p. Disponível em <http://bibliotecadigital.fgv.br>.Acesso em 17 de jan. 2018.

GIORDAN, Murillo; BARKI, Teresa Villac Pinheiro. Licitações e contratações públicas sustentáveis. $1^{a}$ ed. Belo Horizonte: Fórum, 2011. 298 p.

HEIDERMAN, Francisco G; SALIM, José Francisco. Políticas Públicas e

Desenvolvimento: Bases Epistemológicas e Modelos de Análise. Brasília: Editora UnB, 2009.

JARDIM, Arnaldo; YOSHIDA, Consuelo; MACHADO FILHO, José Valverde. Política nacional, gestão e gerenciamento de resíduos sólidos. $1^{\mathrm{a}}$ ed. São Paulo: Manole, 2012. $23 \mathrm{p}$.

JARDIM, Leila Maria de Souza. Gestão Ambiental no Poder Judiciário do Estado do Tocantins: Análise do Tribunal de Justiça, com Foco na Educação Ambiental Proposta de Educação Ambiental. Dissertação Mestrado em Direitos Humanos, Esmat/UFT, Palmas/TO, 2016. 
JURAS, I. A. G. M. Debate sobre a nova lei floresta: análise dos textos aprovados na câmara e no senado. In: Comitê Brasil em Defesa das Florestas e do Desenvolvimento Sustentável (org). Código Florestal e a ciência: o que nossos legisladores ainda precisam saber. Comitê Brasil: Brasília, 2012.

KAPLAN, Robert; NORTON, David. Kaplan e Norton na Prática. $1^{\text {a }}$ ed. Rio de Janeiro: Elsevier. 2004. 126 p. Tradução de Afonso Celso de Cunha Serra.

KLEIN, Naomi. Tudo pode mudar: Capitalismo vs Clima. $1^{a}$ Edição. Lisboa: Editora Presença. 2016. 697 p. Tradução Ana Cristina Pais.

LAGO, André Aranha Corrêa do. Estocolmo, Rio, Joanesburgo: O Brasil e as três conferências ambientais das nações unidas. $1^{\mathrm{a}}$ ed. Brasília: Instituto Rio Branco/ Fundação Alexandre de Gusmão, 2006. 276 p.

LAYRARGUES, Philippe P. Educação Ambiental Crítica: nomes e endereçamentos da educação. $1^{\mathrm{a}}$ ed. Brasília: MMA, 2004. 160 p.

LEFF, Henrique. A complexidade ambiental. São Paulo: Cortez, 2012.

LENZA, Pedro. Direito Constitucional Esquematizado. São Paulo: Editora Saraiva, 2010 .

LINHARES, Elaine de Assis Guerra. Manual Pesquisa Qualitativa. $1^{\text {a }}$ ed. Belo Horizonte: Anima Educação EAD. 2014. 52 p.

LÜDKE, Menga. ANDRÉ, Marli. Pesquisa em educação: abordagens qualitativas. $1^{\text {a }}$ ed. São Paulo: EPU, 1986. 22 p.

MACEDO, Laura Valente; FREITAS, Paula Gabriela de Oliveira. Construindo cidades verdes: Manual de políticas públicas para construções sustentáveis. $1^{a}$ ed. São Paulo: ICLEI-Brasil, 2011. 80 p.

MANZINI, Eduardo José. Entrevista Semi-estruturada: Análise de Objetivos e de Roteiros. In: Seminário Internacional sobre Pesquisa e Estudos Qualitativos, 2, 2004, Bauru. A pesquisa Qualitativa em debate. Bauru USC, 2004, 10p. Disponível em: <http://www.sepq.org.br/ilsipeq/anais/pdf/gt3/04.pdf>. Acesso em 12 fev. 2018.

MARCATTO, Celso. Educação Ambiental: Conceitos e Princípios. $1^{\text {a }}$ ed. Belo Horizonte: FEAM - Fundação Estadual do Meio Ambiente, 2002. 64 p.

MARCONI, Marina de Andrade; LAKATOS, Eva Maria. Fundamentos de Metodologia Científica. 6 ${ }^{a}$ ed. São Paulo: Atlas, 1999.

MEIRELLES, Hely Lopes. Direito administrativo brasileiro. $28^{\text {a }}$ ed. São Paulo: Malheiros, 2003. Atualizada por Eurico Andrade Azevedo; Délcio Balestero Aleixo; José Emmanuel Burle Filho, 968 p. 
MENEGUZZI, Rosa Maria. Conceito de licitação sustentável. Belo Horizonte: Fórum, 2011.

MEYER, Murilo Machado. Gestão ambiental no setor mineral: Um estudo de caso. 2000. 175 f. Dissertação (Mestrado em Engenharia da Produção) -Programa de Pósgraduação em Engenharia da Produção, Universidade Federal de Santa Catarina, Florianópolis, SC 2000.

MINAYO, Maria Cecília de Souza. O desafio do conhecimento. $11^{\text {a }}$ ed. São Paulo: Hucitec, 2008. 408 p.

MONOSOWSKI, Elizabeth. Políticas Ambientais e Desenvolvimento no Brasil. Cadernos Fundap. São

Paulo, v 9, n 16, p. 15-24, jun. 1989.

MOURA, Adriana Maria Magalhães de. O Uso do Poder de Compra para a Melhoria do Meio Ambiente: o Papel da Rotulagem Ambiental. Sustentabilidade ambiental no Brasil: biodiversidade, economia e bem-estar humano / Instituto de Pesquisa Econômica Aplicada. Brasília, n 7, p. 1-11, jan - jun. 2013.

NASCIMENTO, Luis Felipe. Gestão Ambiental e Sustentabilidade. $1^{\text {a }}$ ed. Florianópolis: Departamento de Ciências da Administração/UFSC. CAPES: UAB, 2012.42 p.

NEBLLA, Tom. Integração entre o meio ambiente e o desenvolvimento: 1972-2002. PROGRAMA DAS NAÇÕES UNIDAS PARA O MEIO AMBIENTE - PNUMA. Perspectivas do Meio Ambiente Mundial GEO-3. Brasília, 2004, p. 1-28.

NETO, Zaleski. No limiar da quarta revolução industrial: iniciativas para sustentabilidade por empresas líderes do setor automotivo rumo à nova economia. Revista de Administração FACES, v. 12, n. 3, p. 82-95, 2013.

NICOLAIDES, Angelo. The implementation of environmental management towards sustainable universities and education for sustainable development as an ethical imperative. International Journal of Sustainability in Higher Education, vol. 7, $\mathrm{n}^{\circ}$ 4, p. $414-424,2006$. Texto traduzido

ODA, Marcel. Logística Sustentável: contribuição a processos de gestão. Interfacehs: Revista de Gestão Integrada em Saúde do Trabalho e Meio Ambiente, v. 4, n. 1, p. 126, 2009.

ORGANIZAÇÃO DAS NAÇÕES UNIDAS. Declaração de Joanesburgo sobre desenvolvimento sustentável. 2002. Disponível em:<http/www.onu.org.br/rio20/documentos/>. Acesso em: 25 nov. 2017.

PECCATIELLO, Ana Flávia Oliveira. Políticas públicas ambientais no Brasil: da administração dos recursos naturais (1930) à criação do Sistema Nacional de Unidades de Conservação. Desenvolvimento e Meio Ambiente, Curitiba, n. 24, p. 71-82, jul - dez. 2011. 
PEROVANO, Dalton Gean. Manual de Metodologia Científica. $1^{\text {a }}$ ed. São Paulo: Jurua Editora, 2014.230 p.

PHILIPPI JR., Arlindo; BRUNA, Gilda Collet; ROMERO, Marcelo de Andrade. Curso de gestão ambiental. $2^{\mathrm{a}}$ ed. Barueri: Manole, 2013. 2013 p.

RABELO, Laudemira Silva. Indicadores de Sustentabilidade: a possibilidade do Desenvolvimento Sustentável. 170 f. Dissertação (Mestrado em Desenvolvimento e Meio Ambiente) Prodema, UFC. Fortaleza, CE, 2008.

REINISCH, Christianne Coelho de Souza. A questão ambiental dentro das indústrias de Santa Catarina: Uma abordagem para o segmento industrial têxtil. 1996. $224 \mathrm{f}$. Dissertação (Mestrado em Engenharia de Produções e Sistemas) - Universidade Federal de Santa Catarina, Florianópolis, 1996.

RICHARDSON, Roberto Jarry. Pesquisa social: métodos e técnicas. $3^{\mathrm{a}}$ ed. São Paulo: Atlas, 2012. 168 p.

RUA, Maria das Graças. Políticas Públicas. $1^{a}$ ed. Florianópolis: UFSC CAPES, 2009. $163 \mathrm{p}$.

SACHS, Ignacy. Estratégias de transição para o século XXI. In: Para pensar o desenvolvimento sustentável. São Paulo, Brasiliense: 2008.

SECCHI, Leonardo. Políticas públicas: conceitos, esquemas de análise, casos práticos. $2^{\mathrm{a}}$ edição. São Paulo: Cengage Learning, 2010. 133 p.

SEIFFERT, Mari Elizabete. Gestão ambiental: instrumentos, esferas de ação e educação ambiental. $3^{a}$ Ed. São Paulo: Atlas, 2014. 328 p.

SILVA, Carlos Henrique R Tomé. Rio+20: Avaliação Preliminar de Resultados e Perspectivas da Conferência das Nações Unidas sobre Desenvolvimento Sustentável. Senado Federal. Consultoria Legislativa. Brasília: 2012. Boletim Legislativo, no 1.

SOUZA, Celina. Políticas públicas: uma revisão da literatura. Sociologias, Porto Alegre, ano 8, n' 16 , p. 20-45, 2006.

Tribunal de Justiça do Estado do Tocantins. Institui Plano de Logística Sustentável do Poder Judiciário do Tocantins. Disponível em: <http://wwa.tjto.jus.br/diario/diariopublicado/2492.pdf>. Acesso em 26 jan. de 2018.

THEODORSON, George; THEODORSON, Aquilles. A modern dictionary of sociology $.2^{\text {a }}$ ed. London: Methuen, 1970. 496 p.

TINOCO, João Eduardo Prudêncio; KRAEMER, Maria Elizabeth Pereira. Contabilidade e Gestão Ambiental. $3^{\text {a }}$ ed. São Paulo: Atlas, 2011. 296 p. 
VAMPRÉ, Spencer. Poder Judiciário Estadual e Sustentabilidade: O aprimoramento dos mecanismos de solução de conflitos ambientais no Estado do Tocantins. Dissertação Mestrado em Prestação Jurisdicional e Direitos Humanos, Esmat/UFT, Palmas/TO, 2015. 


\section{APÊNDICES}


APÊNDICE A - Termo de Consentimento Livre Esclarecido

\section{$\underline{\text { Dados de identificacão }}$}

Título do Projeto: Institucionalização da Gestão Sustentável no Tribunal de Justiça do Tocantins

Pesquisador Responsável: Nadia Becmam Lima

Nome do participante:

Data de nascimento:

R.G.:

Você está sendo convidado (a) para participar, como voluntário, do projeto de pesquisa Institucionalização da Gestão Sustentável no Tribunal de Justiça do Tocantins, de responsabilidade da pesquisadora Nadia Becmam Lima, orientada pela Professora Doutora Lia Azevedo Almeida, ligada ao Programa de Mestrado de Gestão de Políticas Públicas da Universidade Federal do Tocantins.

Leia cuidadosamente o que segue e me pergunte sobre qualquer dúvida que você tiver. Após ser esclarecido (a) sobre as informações a seguir, no caso aceite fazer parte do estudo, assine ao final deste documento, que consta em duas vias. Uma via pertence a você e a outra ao pesquisador responsável.

\section{Declaro ter sido esclarecido sobre os seguintes pontos:}

1. O trabalho tem por finalidade analisar o processo de institucionalização da gestão socioambiental na Administração Pública no âmbito do Tribunal de Justiça do Tocantins, para se for o caso, sugerir melhorias a partir de possíveis deficiências identificadas.

2. A pesquisa consistirá em realizar análise documental nos instrumentos normativos editados pelo próprio Tribunal, relatórios disponíveis que incluem os indicadores apresentados no PLS e resultados com as ações desenvolvidas no período compreendido entre 2014 a 2017 e entrevista por meio de aplicação de roteiro já pré-estabelecido.

3. Ao participar desse trabalho estarei contribuindo para o aprimoramento do Plano de Gestão Ambiental do Tribunal de Justiça do Tocantins, vislumbrando a melhoria e ou implantação da gestão socioambiental em outras comarcas do Estado. 
4. A minha participação neste projeto terá a duração necessária para responder a entrevista proposta.

5. Não terei nenhuma despesa ao participar da pesquisa e poderei deixar de participar ou retirar meu consentimento a qualquer momento, sem precisar justificar, e não sofrerei qualquer prejuízo.

6. Fui informado e estou ciente de que não há nenhum valor econômico, a receber ou a pagar, por minha participação, no entanto, caso eu tenha qualquer despesa decorrente da participação na pesquisa, serei ressarcido.

7. Meu nome será mantido em sigilo, assegurando assim a minha privacidade, e se eu desejar terei livre acesso a todas as informações e esclarecimentos adicionais sobre o estudo e suas consequências, enfim, tudo o que eu queira saber antes, durante e depois da minha participação.

8. Fui informado que os dados coletados serão utilizados, única e exclusivamente, para fins desta pesquisa, e que os resultados poderão ser publicados.

9. Qualquer dúvida, pedimos a gentileza de entrar em contato com Nadia Becmam Lima (mestranda), telefone: 981379820, e-mail: nabecklim@yahoo.com.br e Professora Doutora Lia Azevedo Almeida, email: lia_aalmeida@hotmail.com.

$\mathrm{Eu}$,

$\mathrm{RG} \quad \mathrm{n}^{\mathrm{o}}$ declaro ter sido informado e concordo em participar, como voluntário, da pesquisa acima descrita.

Palmas/TO, de de 2018.

Assinatura do participante 
APÊNDICE B - Roteiro Entrevista Semiestruturada baseada no trabalho de REK (2017) que fez análise semelhante no Tribunal Regional Eleitoral do Paraná.

ROTEIRO QUESTIONÁRIO “A” - (SERVIDORES - Diretores e Chefes de Divisões)

\section{INSTITUCIONALIZAÇÃO DA GESTÃO SUSTENTÁVEL NO TRIBUNAL DE JUSTIÇA DO TOCANTINS}

\section{DADOS DE IDENTIFICACÃO E PARTICIPACÃO}

Data da entrevista:

Função:

Formação acadêmica:

\section{I - CONHECIMENTO DA TEMÁTICA E LEGISLAÇ̃̃O AMBIENTAL}

01 - Dentre as opções abaixo, como classificaria o seu nível de consciência socioambiental?
[ ] Péssimo
[ ] Ruim [ ] Bom
[ ] Ótimo [ ] Excelente

02 - Assinale de acordo com seus conhecimentos referentes à questão socioambiental:

\begin{tabular}{|l|l|l|l|}
\hline \multicolumn{1}{|c|}{ QUESTÕES } & SIM & NÃO & $\begin{array}{l}\text { Conheço } \\
\text { Parcialmente }\end{array}$ \\
\hline $\begin{array}{l}\text { Você conhece o tema sustentabilidade e gestão } \\
\text { ambiental? }\end{array}$ & & & \\
\hline Você conhece práticas de sustentabilidade ambiental? & & & \\
\hline $\begin{array}{l}\text { Você tem conhecimento a respeito da Comissão } \\
\text { Socioambiental no TJ/TO? }\end{array}$ & & \\
\hline $\begin{array}{l}\text { Você conhece as competências e ações desenvolvidas } \\
\text { pela Comissão Socioambiental no TJ/TO? }\end{array}$ & & & \\
\hline $\begin{array}{l}\text { Você conhece o Programa Agenda Ambiental na } \\
\text { Administração Pública - A3P? }\end{array}$ & & & \\
\hline $\begin{array}{l}\text { Você conhece o Plano de Logística Sustentável do } \\
\text { TJ/TO? }\end{array}$ & & & \\
\hline $\begin{array}{l}\text { Você tem conhecimento acerca do "uso sustentável de } \\
\text { recursos naturais e bens públicos" na Administração } \\
\text { Pública? }\end{array}$ & & & \\
\hline $\begin{array}{l}\text { Você tem conhecimento acerca da gestão adequada de } \\
\text { resíduos gerados na Administração Pública? }\end{array}$ & & & \\
\hline
\end{tabular}

03 - Dentre os normativos que orientam a implantação de práticas socioambientais no âmbito do Poder Judiciário e, especificamente no TJ/TO, assinale aqueles de seu conhecimento:

[ ] Recomendação $n^{\circ} .11 / 2007$ do CNJ

[ ] Resolução $n^{\circ}$. 201/2015 do CNJ

[ ] Portaria no . 4.119/2014 - Institui a Comissão Permanente Socioambiental do TJ/TO

[ ] Plano de Logística Sustentável do Tribunal de Justiça do Tocantins (PLS - TJ/TO) 


\section{II - A COMISSÃO SOCIOAMBIENTAL E SUA RELAÇ̃̃O COM A INSTITUIC̄̃̃O}

04- Em sua opinião, quais ações devem ser implementadas pela Comissão Socioambiental para a efetividade da questão socioambiental $\mathrm{TJ} / \mathrm{TO}$ ?

\section{III - A QUESTÃO SOCIOAMBIENTAL E A INSTITUCIONALIZAĊ̃̃O NO TJ/TO}

05 - Foi realizado algum diagnóstico para a identificação dos prováveis impactos ambientais decorrentes de suas atividades?

[ ] Sim [ ] Não

06 - Foi realizada a mensuração ou levantamento estatístico das práticas socioambientais porventura realizadas? [ ] Sim [ ] Não

07 - A mensuração ou levantamentos estatísticos de práticas socioambientais são disponibilizados ou reportados pela Comissão Socioambiental do TJ/TO?

[ ] Sim [ ] Não

\section{IV - SENSIBILIZAĊ̃̃O E CAPACITAĊ̃̃O SOCIOAMBIENTAL NO TJ/TO}

08 - Você obtém conhecimentos referentes às práticas e normativos socioambientais no âmbito do TJ/TO por meio de:

[ ] Informativos ou orientações em e-mail institucional

[ ] Cursos e treinamentos

[ ] Publicações no Diário da Justiça

[ ] Comissão Socioambiental (Página ou Blog)

[ ] PAD - Processo Administrativo Digital

[ ] outro (s) Especifique

09 - A comissão socioambiental contribui com a sensibilização dos servidores, possibilitando o acesso a informações, esclarecimentos e normativos ambientais vigentes no âmbito do TJ/TO?

[ ] Sempre [ ] Às vezes [ ] Nunca

10 - Relacione, dentre as opções abaixo, de que modo ocorre a sensibilização e capacitação socioambiental proporcionada pela Comissão Socioambiental.

[ ] cursos e treinamentos

[ ] folders e/ou cartazes

[ ] orientações por email institucional

[ ] fóruns ou debates

[ ] outro(s) Especifique 
11 - A seu ver, as ações e informações disponibilizadas pela comissão socioambiental são suficientes e eficazes para a incorporação de práticas socioambientais?

[ ] Sim [ ] Não [ ] Precisam melhorar.

12 - Há a sensibilização ambiental orientada a colaboradores e/ou prestadores de serviço?

[ ] Sim [ ] Não [ ] Parcialmente

\section{V-PRÁTICAS SOCIOAMBIENTAIS}

13 - São desenvolvidas ações ou práticas socioambientais no TJ/TO?

[ ] Sim [ ] Não

14 - Com que frequência é realizada atividades ou práticas ambientais no TJ/TO?

[ ] Permanentemente [ ] Esporadicamente [ ] Nunca [ ] Muitas vezes.

15 - As ações ou práticas socioambientais realizadas neste Tribunal ocorrem:

[ ] Voluntariamente, em razão da consciência ambiental dos servidores

[ ] Obrigatoriamente, em decorrência de normatização

[ ] Pelas duas razões anteriores

[ ] Não ocorrem

16 - Caso as ações ambientais tivessem apenas caráter voluntário, continuariam sendo desenvolvidas neste Tribunal?

[ ] Sim [ ] Não

17 - Relacione abaixo quais são os atores efetivamente envolvidos no desempenho das práticas ambientais no TJ/TO:

[ ] Servidores efetivos

[ ] Requisitados

[ ] Estagiário

[ ] Terceirizados/colaboradores

18 - Considerando o Eixo Temático Uso Racional dos Recursos Naturais e Bens Públicos da A3P, bem como a Resolução 201/2015 do CNJ, identifique abaixo, dentre as práticas de sustentabilidade, a efetividade da ação correlacionada a este Tribunal de Justiça:

\begin{tabular}{|c|c|c|c|c|c|}
\hline \multicolumn{2}{|c|}{$\begin{array}{c}\text { PRÁTICAS - USO RACIONAL DE RECURSOS } \\
\text { NATURAIS E BENS PÚBLICOS }\end{array}$} & \multicolumn{4}{|c|}{$\begin{array}{l}\text { Efetividade da Prática no } \\
\text { TJ/TO }\end{array}$} \\
\hline Indicador & $\begin{array}{l}\text { Especificação } \\
\end{array}$ & \multicolumn{2}{|c|}{ Conhecida } & \multicolumn{2}{|c|}{$\begin{array}{l}\text { Implementa } \\
\text { da }\end{array}$} \\
\hline \multirow{3}{*}{$\begin{array}{c}\text { Consumo de } \\
\text { Energia Elétrica }\end{array}$} & & Sim & Não & Sim & Não \\
\hline & Monitoramento da energia na unidade & & & & \\
\hline & $\begin{array}{l}\text { Promoção da sensibilização de servidores } \\
\text { e colaboradores quanto ao uso racional de }\end{array}$ & & & & \\
\hline
\end{tabular}




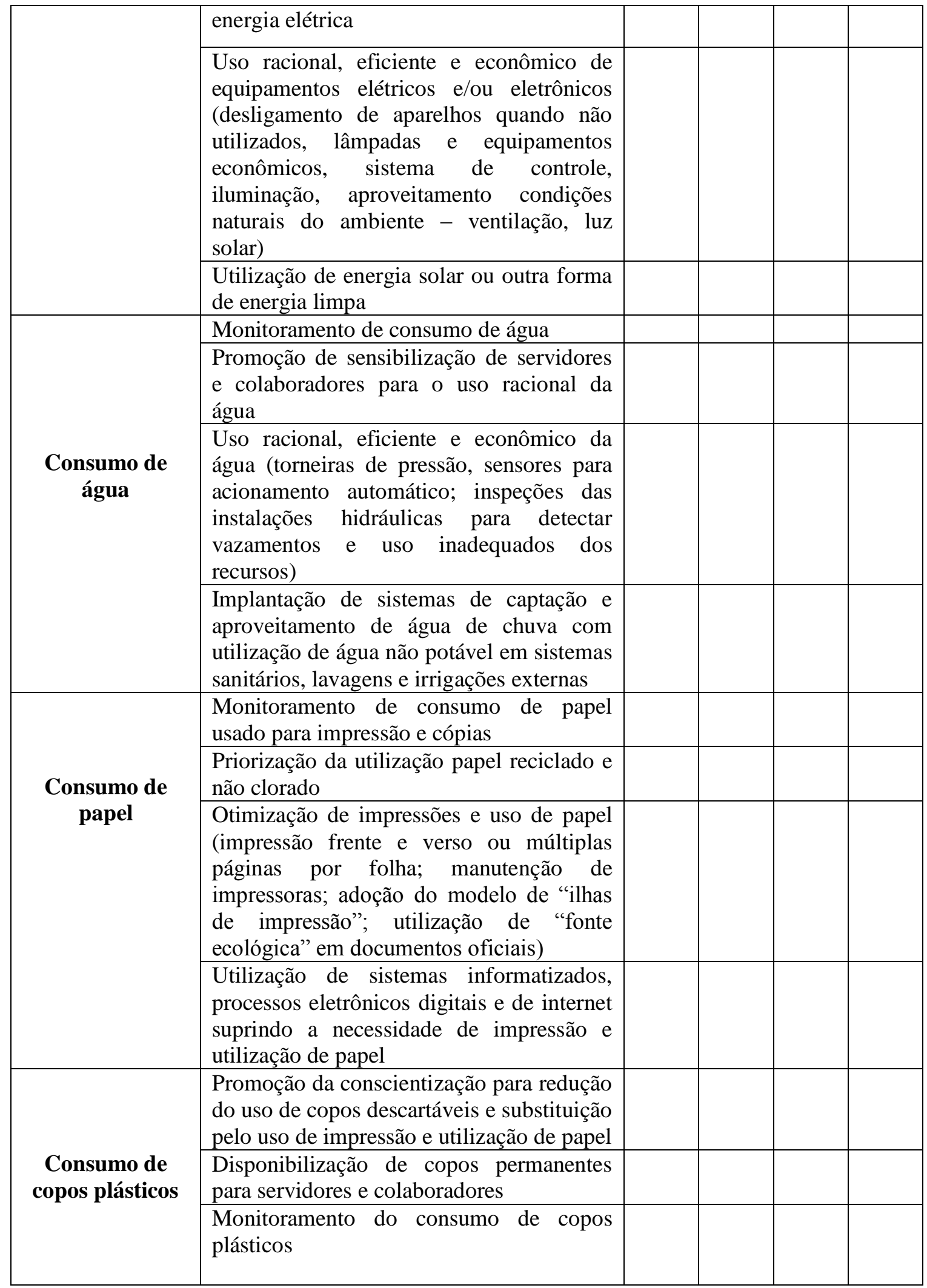

19 - Considerando o Eixo Temático Gestão Adequada dos Resíduos Gerados da A3P, bem como a Resolução 201/2015 do CNJ, identifique abaixo, dentre as práticas de sustentabilidade, a efetividade da ação correlacionada a este Tribunal de Justiça: 


\begin{tabular}{|c|c|c|c|c|c|}
\hline \multicolumn{2}{|r|}{ GERADOS } & \multicolumn{4}{|c|}{ TJ/TO } \\
\hline Indicador & \multirow[t]{2}{*}{ Especificação } & \multicolumn{2}{|c|}{ Conhecida } & \multicolumn{2}{|c|}{$\begin{array}{l}\text { Implementa } \\
\text { da }\end{array}$} \\
\hline \multirow{6}{*}{ Coleta Seletiva } & & Sim & Não & Sim & Não \\
\hline & $\begin{array}{l}\text { Reciclagem (de papel, papelão, plásticos, } \\
\text { cartuchos de toner) }\end{array}$ & & & & \\
\hline & $\begin{array}{l}\text { Descarte e destinação corretos de materiais } \\
\text { recicláveis e não recicláveis }\end{array}$ & & & & \\
\hline & $\begin{array}{l}\text { Destinação de material reciclável às } \\
\text { cooperativas ou associações de catadores } \\
\text { cadastradas de materiais recicláveis (coleta } \\
\text { seletiva solidária) }\end{array}$ & & & & \\
\hline & $\begin{array}{l}\text { Separação adequada de resíduos gerados } \\
\text { (papel, plástico, vidro, metal, comum ou } \\
\text { materiais recicláveis e não recicláveis) }\end{array}$ & & & & \\
\hline & $\begin{array}{l}\text { Conscientização e sensibilização de } \\
\text { servidores e colaboradores quanto à } \\
\text { destinação de resíduos e aplicação da } \\
\text { Política dos 5R's (repensar, recusar, reduzir, } \\
\text { reutilizar e reciclar) }\end{array}$ & & & & \\
\hline \multirow{4}{*}{$\begin{array}{l}\text { Gestão de } \\
\text { Resíduos } \\
\text { perigosos }\end{array}$} & $\begin{array}{l}\text { Descarte adequado de resíduos perigosos } \\
\text { (lâmpadas fluorescentes, pilhas, baterias) }\end{array}$ & & & & \\
\hline & $\begin{array}{l}\text { Utilização de logística reversa de resíduos } \\
\text { perigosos (lâmpadas, pilhas, baterias, } \\
\text { cartuchos e toners não recicláveis) }\end{array}$ & & & & \\
\hline & Elaboração de plano de gestão de resíduos & & & & \\
\hline & $\begin{array}{l}\text { Destinação adequada de lixo eletrônico } \\
\text { (computadores, telefones, aparelhos) }\end{array}$ & & & & \\
\hline
\end{tabular}

20 - Dentre as opções abaixo, assinale quais são as principais dificuldades identificadas neste Tribunal quanto à implantação de práticas socioambientais?
[ ] Falta de informações e/ou esclarecimentos
[ ] Burocracia
[ ] Desinteresse da equipe interna
[ ] Falta de normas ou regulamentos
[ ] Indisponibilidade de tempo
[ ] Falta de estímulo, apoio ou motivação
[ ] Ausência de fiscalização efetiva
[ ] Indisponibilidade de pessoal
[ ] Outra(s). Especifique

21 - Para você, quais as ações, instrumentos ou estratégias são importantes para a efetividade das práticas socioambientais no Tribunal de Justiça?
[ ] Legislação e normas eficazes
[ ] Fiscalização e auditoria das práticas exigidas
[ ] Sensibilização do corpo funcional
[ ] Outras. Especifique: 
22 - A seu ver, as práticas socioambientais implementadas no âmbito do TJ/TO são capazes de minimizar os impactos ambientais negativos?

[ ] Não [ ] Sim.

De que maneira?

23 - No seu ponto de vista, quais os pontos positivos identificados quanto à implantação de práticas socioambientais no $\mathrm{TJ} / \mathrm{TO}$ ?

24 - Para você, as práticas socioambientais desenvolvidas no TJ/TO, podem impactar positivamente para além do âmbito institucional, com reflexos sociais?

[ ] Não [ ] Sim.

De que modo?

25 - Espaço reservado a sugestões, críticas ou comentários. 
APÊNDICE C - Roteiro Entrevista Semiestruturada baseada no trabalho de REK (2017) que fez análise semelhante no Tribunal Regional Eleitoral do Paraná.

QUESTIONÁRIO “B” - (COMISSÃO SOCIOAMBIENTAL - Membros Núcleo Gestão Socioambiental e Comissão Gestora do Plano de Logística Sustentável)

\section{INSTITUCIONALIZAÇÃO DA GESTÃO SUSTENTÁVEL NO TRIBUNAL DE JUSTIÇA DO TOCANTINS}

\section{DADOS DE IDENTIFICAÇ̃̃O E PARTICIPAÇÃO}

Data da entrevista:

Função:

Formação acadêmica:

\section{I-A QUESTÃO SOCIOAMBIENTAL E A INSTITUCIONALIZACẼO NO TJ/TO}

01 - Na sua visão, há o comprometimento institucional quanto à questão ambiental e implantação das práticas ambientais no Tribunal como um todo?

[ ] Sim [ ] Não

02 - A seu ver, a institucionalização da gestão socioambiental no TJ/TO, numa escala hipotética de medição, está num nível:

[ ] Inicial [ ] Médio [ ] Avançado

03 - Em sua opinião, há o comprometimento dos departamentos no concernente à incorporação das práticas socioambientais as suas respectivas atividades?

[ ] Sempre [ ] Na maioria das vezes [ ] Raramente [ ] Nunca

04 - Identifica-se no corpo funcional e demais colaboradores, resistência, dificuldade ou negação para a incorporação de práticas socioambientais e mudança de hábitos?

[ ] Muita [ ] Pouca [ ] Nenhuma

05 - Há alguma previsão e/ou disponibilização orçamentária destinada ao desenvolvimento de ações e práticas socioambientais no âmbito do TJ/TO?

[ ] Sim [ ]Não [ ] Precisa melhorar.

06 - Existe algum canal de acesso à população/sociedade, no qual sejam franqueadas informações correlatas às práticas socioambientais implementadas no Tribunal, bem como, para reclamações, sugestões ou críticas? [ ] Sim [ ] Não

07 - De que modo a sociedade pode apresentar sugestões, reclamações, críticas ou obter informações quanto aos aspectos socioambientais no $\mathrm{TJ} / \mathrm{TO}$ ? 
08 - Quais das etapas abaixo foram implementadas quanto à institucionalização da gestão socioambiental no TJ/TO?

[ ] Diagnóstico socioambiental

[ ] Planejamento, elaboração e implementação de indicadores e metas

[ ] Sensibilização de servidores e colaboradores quanto às práticas socioambientais;

[ ] Capacitação de servidores e colaboradores

[ ] Monitoramento das ações implementadas

[ ] Avaliação das práticas efetivadas

[ ] Revisão de ações e práticas

[ ] Prestação de contas à sociedade (relatórios com resultados obtidos)

09 - Por ocasião da institucionalização das práticas ambientais no TJ/TO, identifique no quadro abaixo como se dá a abordagem e implantação de cada uma das seguintes fases:

\begin{tabular}{|l|l|l|}
\hline \multicolumn{1}{|c|}{ FASES E AÇÕES } & $\begin{array}{c}\text { Abordagem } \\
\text { Individualizada por } \\
\text { Departamento }\end{array}$ & Abordagem geral TJ \\
\hline Diagnóstico Socioambiental & & \\
\hline $\begin{array}{l}\text { Elaboração de metas e indicadores de } \\
\text { sustentabilidade ambiental }\end{array}$ & & \\
\hline Sensibilização de servidores & & \\
\hline Monitoramento de ações & & \\
\hline Avaliação das práticas efetivadas & & \\
\hline Revisão de ações e práticas & & \\
\hline Prestação de Contas & & \\
\hline
\end{tabular}

10 - Para você, quais as ações são necessárias para que a institucionalização da gestão socioambiental no TJ/TO seja efetiva?

\section{II - A COMISSÃO SOCIOAMBIENTAL E SUA RELACÃO COM A} INSTITUIĈ̃̃

11 - Na sua percepção, as ações desenvolvidas pela Comissão Socioambiental são conhecidas por todos os departamentos do Tribunal?

[ ] Sim [ ]Não [ ] Pela maioria [ ] Apenas por alguns

12 - De acordo com sua visão, os servidores do TJ/TO reconhecem a Comissão Socioambiental, bem como, as práticas socioambientais como de caráter:

[ ] Facultativo [ ] Voluntário [ ] Obrigatório 
13 - A administração superior do Tribunal reconhece a Comissão Socioambiental, bem como, as práticas socioambientais como de caráter:

[ ] Facultativo [ ] Voluntário [ ] Obrigatório

14 - A administração superior envida ações no sentido de estimular as atividades da Comissão Socioambiental e a efetivação das práticas ambientais no âmbito do TJ/TO?

[ ] Sempre [ ] Na maioria das vezes [ ] Raramente [ ] Nunca

15 - Para você, quais aspectos colaborariam para a otimização do desempenho e funcionamento da Comissão Socioambiental?

16 - Em sua opinião, quais ações devem ser implementadas pela Comissão Socioambiental para a efetividade da questão ambiental no TJ/TO?

\section{III - SENSIBILIZACÃO E CAPACITACÃO SOCIOAMBIENTAL NO TJ/TO}

17 - Relacione, dentre as opções abaixo, de que modo ocorre a sensibilização e capacitação socioambiental realizada pela Comissão Socioambiental.

[ ] cursos e treinamentos

[ ] folders e/ou cartazes

[ ] e-mail institucional

[ ] fóruns ou debates

[ ] palestras

[ ] outro(s). Especifique:

18 - Em sua opinião, qual a forma mais efetiva de sensibilização socioambiental?

[ ] cursos e treinamentos

[ ] folders e/ou cartazes

[ ] e-mail institucional

[ ] fóruns ou debates

[ ] palestras

[ ] outro(s). Especifique: 
19 - A comissão socioambiental colabora com o acesso às informações, esclarecimentos, sensibilização de servidores do TJ/TO, quanto a práticas e normativos socioambientais vigentes?

[ ] Sempre [ ] Às vezes [ ] Nunca

20 - A seu ver, as ações e informações disponibilizadas pela comissão socioambiental são suficientes e eficazes para a incorporação de práticas socioambientais no TJ/TO?

[ ] Sim [ ] Não. [ ] Precisam melhorar.

\section{IV - PRÁTICAS SOCIOAMBIENTAIS}

21 - Em sua opinião, as ações ou práticas socioambientais no TJ/TO ocorrem:

[ ] Voluntariamente, em razão da consciência ambiental dos servidores

[ ] Obrigatoriamente, em decorrência de normatização

[ ] Pelas duas razões anteriores

[ ] Não ocorrem

22 - Relacione, dentre os atores abaixo, quais os efetivamente envolvidos no desempenho e institucionalização das práticas socioambientais no Tribunal:

[ ] Administração Superior
[ ] Servidores efetivos
[ ] Requisitados
[ ] Estagiários
[ ] Terceirizados/colaboradores

23 - Para você, quais as ações, instrumentos ou estratégias são importantes para a efetividade das práticas ambientais no Tribunal?

[ ] Legislação e normas eficazes

[ ] Fiscalização e auditoria das práticas exigidas

[ ] Sensibilização do corpo funcional

[ ] Comprometimento de servidores e colaboradores

[ ] Outras. Especifique:

24 - A seu ver, as ações e práticas socioambientais implementadas no âmbito do TJ/TO são capazes de minimizar os impactos ambientais negativos?

[ ] Não [ ] Sim.

De que maneira?

25 - Dentre as opções abaixo, assinale quais são as principais dificuldades identificadas para a implantação de práticas socioambientais no TJ/TO: 
[ ] Falta de informações e/ou esclarecimentos

[ ] Burocracia

[ ] Ausência de comprometimento e interesse do corpo funcional

[ ] Ausência de comprometimento e interesse de colaboradores

[ ] Insuficiência/ausência de normas ou regulamentos

[ ] Falta de tempo

[ ] Falta de estímulo, apoio ou motivação

[ ] Ausência de fiscalização efetiva

[ ] Indisponibilidade de pessoal

[ ] Dificuldade de comunicação

[ ] Outra (s). Especifique:

26 - Considerando o Eixo Temático Uso Racional dos Recursos Naturais e Bens Públicos da A3P, bem como a Resolução 201/2015 do CNJ, identifique abaixo, dentre as práticas de sustentabilidade, a efetividade da ação correlacionada ao TJ/TO:

\begin{tabular}{|c|c|c|c|c|c|}
\hline \multicolumn{2}{|c|}{$\begin{array}{c}\text { PRÁTICAS - USO RACIONAL DE RECURSOS } \\
\text { NATURAIS E BENS PÚBLICOS }\end{array}$} & \multicolumn{4}{|c|}{$\begin{array}{c}\text { Efetividade da Prática no } \\
\text { TJ/TO }\end{array}$} \\
\hline Indicador & $\begin{array}{l}\text { Especificação } \\
\end{array}$ & Cor & ecida & $\begin{array}{l}\text { Impl } \\
\text { da }\end{array}$ & ienta \\
\hline \multirow{6}{*}{$\begin{array}{l}\text { Consumo de } \\
\text { Energia Elétrica }\end{array}$} & & Sim & Não & Sim & Não \\
\hline & $\begin{array}{l}\text { Elaboração e aplicação de plano para } \\
\text { redução do consumo e uso consciente de } \\
\text { energia elétrica }\end{array}$ & & & & \\
\hline & Monitoramento da energia consumida & & & & \\
\hline & $\begin{array}{l}\text { Promoção da sensibilização de servidores } \\
\text { e colaboradores quanto ao uso racional } \\
\text { de energia elétrica }\end{array}$ & & & & \\
\hline & $\begin{array}{l}\text { Uso racional, eficiente e econômico de } \\
\text { equipamentos elétricos e/ou eletrônicos } \\
\text { (desligamento de aparelhos quando não } \\
\text { utilizados, lâmpadas e equipamentos } \\
\text { econômicos, sistema de controle, } \\
\text { iluminação, aproveitamento condições } \\
\text { naturais do ambiente - ventilação, luz } \\
\text { solar) }\end{array}$ & & & & \\
\hline & $\begin{array}{l}\text { Utilização de energia solar ou outra } \\
\text { forma de energia limpa }\end{array}$ & & & & \\
\hline \multirow{4}{*}{$\begin{array}{l}\text { Consumo de } \\
\text { água }\end{array}$} & $\begin{array}{l}\text { Elaboração e aplicação de plano para } \\
\text { redução do consumo e uso consciente de } \\
\text { água }\end{array}$ & & & & \\
\hline & Monitoramento de consumo de água & & & & \\
\hline & $\begin{array}{l}\text { Promoção de sensibilização de servidores } \\
\text { e colaboradores para o uso racional da } \\
\text { água }\end{array}$ & & & & \\
\hline & $\begin{array}{l}\text { Uso racional, eficiente e econômico da } \\
\text { água (torneiras de pressão, sensores para }\end{array}$ & & & & \\
\hline
\end{tabular}




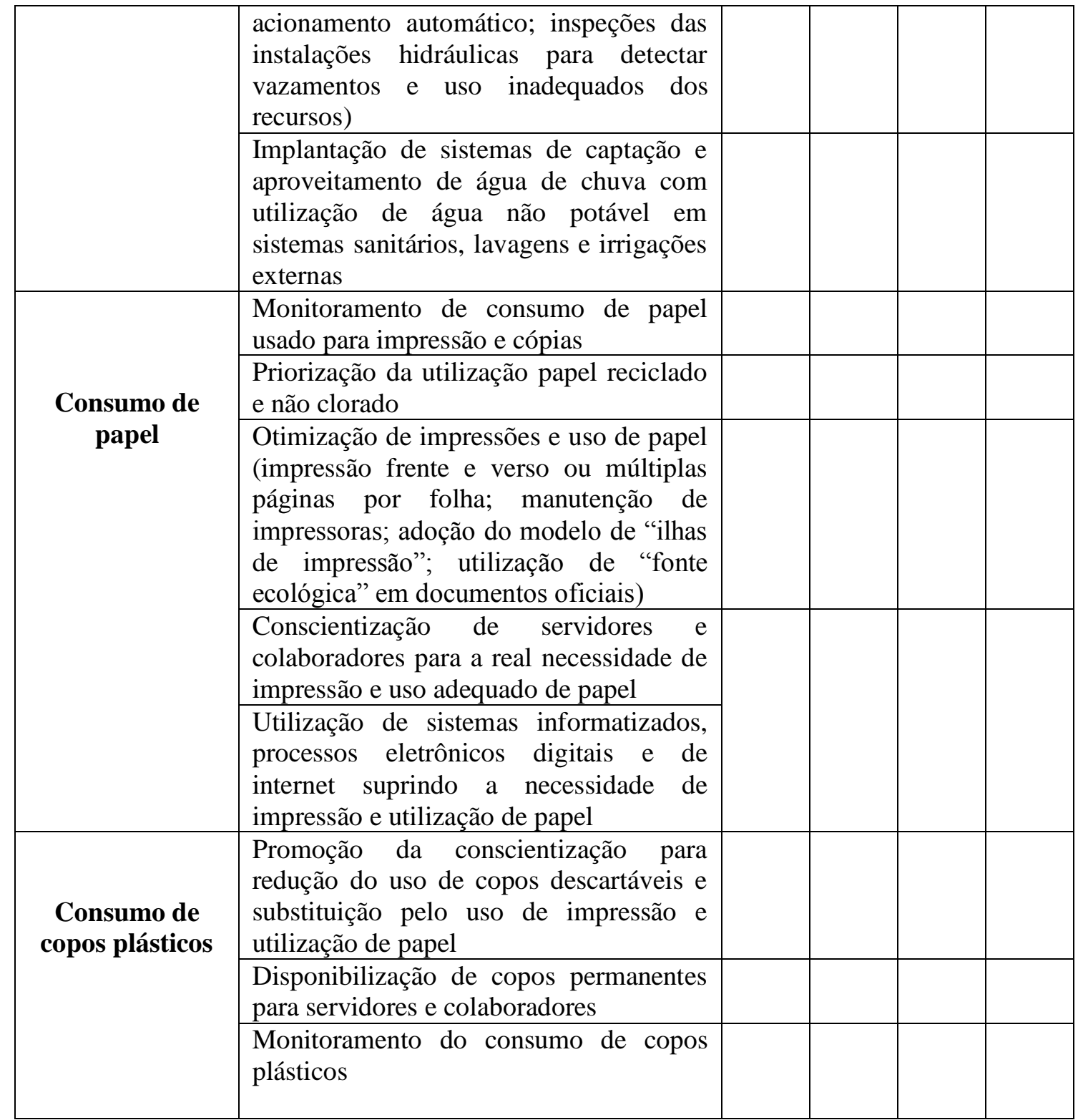

27 - Considerando o Eixo Temático Gestão Adequada dos Resíduos Gerados da A3P, bem como a Resolução 201/2015 do CNJ, identifique abaixo, dentre as práticas de sustentabilidade, a efetividade da ação correlacionada ao TJ/TO:

\begin{tabular}{|c|c|c|c|c|c|}
\hline \multicolumn{2}{|c|}{$\begin{array}{l}\text { PRÁTICAS - GESTÃO ADEQUADA DOS RESÍDUOS } \\
\text { GERADOS }\end{array}$} & \multicolumn{4}{|c|}{$\begin{array}{c}\text { Efetividade da Prática no } \\
\text { TJ/TO }\end{array}$} \\
\hline Indicador & Especificação & Con & cida & Impl & ntada \\
\hline \multirow{4}{*}{ Coleta Seletiva } & & Sim & Não & Sim & Não \\
\hline & $\begin{array}{l}\text { Reciclagem (de papel, papelão, plásticos, } \\
\text { cartuchos de toner) }\end{array}$ & & & & \\
\hline & $\begin{array}{l}\text { Descarte e destinação corretos } \mathrm{de} \\
\text { materiais recicláveis e não recicláveis }\end{array}$ & & & & \\
\hline & $\begin{array}{l}\text { Destinação de material reciclável às } \\
\text { cooperativas ou associações de catadores } \\
\text { cadastradas de materiais recicláveis } \\
\text { (coleta seletiva solidária) }\end{array}$ & & & & \\
\hline
\end{tabular}




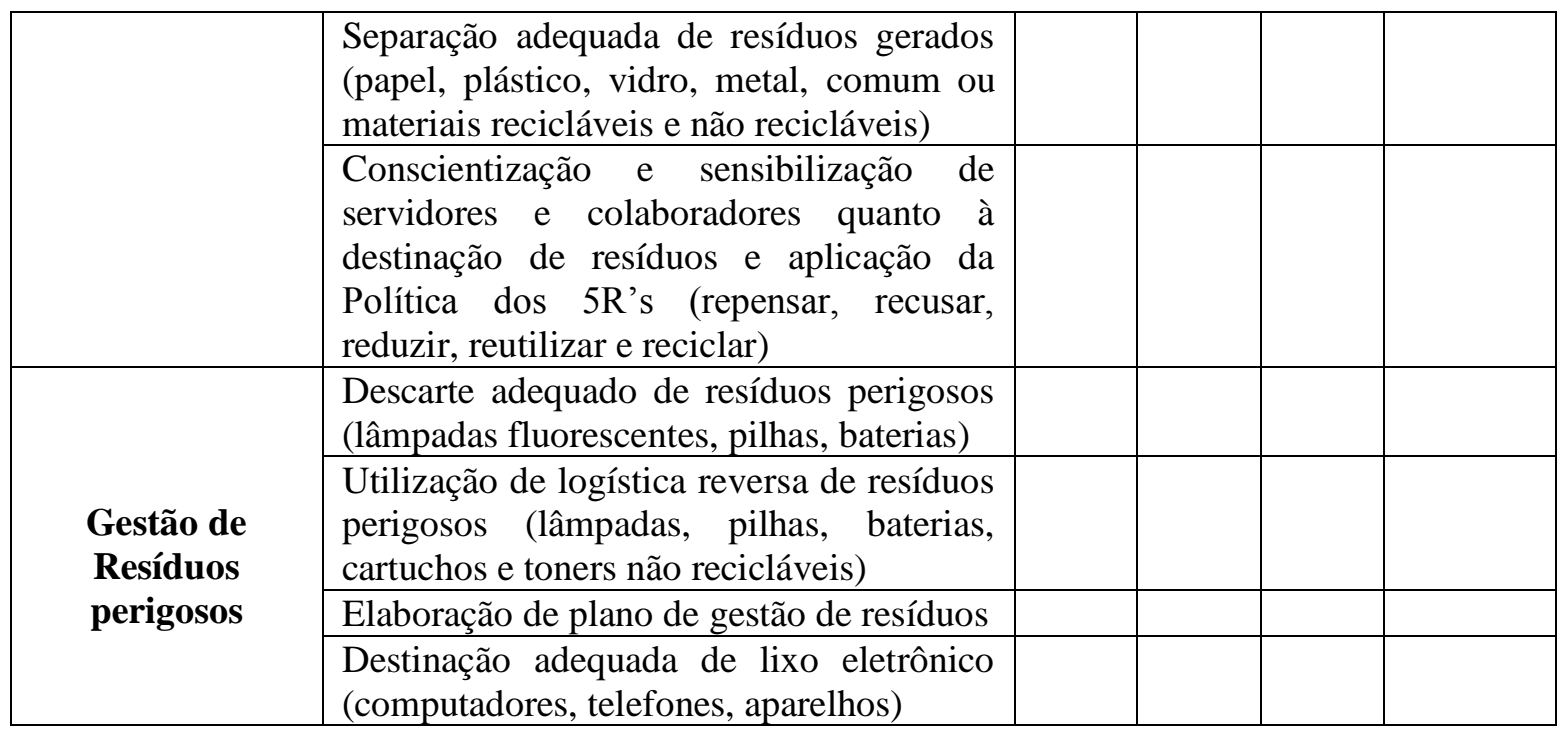

28 - Dentre as práticas relacionadas anteriormente, há alguma específica que represente uma maior dificuldade de implantação? Por quê?

29 - De acordo com a sua visão, assinale os possíveis reflexos derivados da institucionalização das práticas socioambientais?
[ ] Economicidade
[ ] Sustentabilidade de recursos naturais
[ ] Redução do impacto ambiental
[ ] Eficiência da gestão
[ ] Transparência
[ ] Moralidade
[ ] Sensibilização de colaboradores
[ ] Qualidade de vida
[ ] Outros

30 - Espaço reservado a sugestões, críticas ou comentários. 
APÊNDICE D - Proposição de melhorias para a gestão socioambiental do Tribunal de Justiça do Tocantins

A partir das limitações/déficits detectadas durante a análise da institucionalização da gestão socioambiental no Tribunal de Justiça do Tocantins é possível trazer sugestões de ações que podem ser promovidas pela Instituição como forma de contribuição e fortalecimento da gestão socioambiental do órgão, podendo servir de parâmetro para demais órgão da Administração Pública e comarcas do próprio TJTO.

Para a apresentação do rol de práticas socioambientais que seguem abaixo, foi levado em consideração os documentos de instituição da sustentabilidade, diretrizes do planejamento estratégico, PLS e seus relatórios, bem como questionários aplicados aos servidores do órgão e literatura a respeito do tema.

Portanto seguem as sugestões de melhorias para a implementação da gestão sustentável no Tribunal de Justiça do Tocantins:

- Instituir o calendário socioambiental no Tribunal de Justiça do Estado do Tocantins, concedendo a devida publicidade aos servidores;

A instituição de um calendário das ações ligadas principalmente ao eixo temático, capacitação e sensibilização e qualidade de vida no trabalho contribuirá com o monitoramento das metas estabelecidas para as práticas socioambientais.

- $\quad$ Promover em parceria com a Escola Superior de Magistratura ESMAT cursos e ou palestras ao longo do ano.

Importante que as palestras e ou cursos sejam periódicos e contínuos ocorrendo pelo menos de 2 em 2 meses, para ser abordado assuntos relacionados a cada eixo temático de forma individualizada ou agrupado por afinidade, as normas que envolvem a sustentabilidade, ações e programas ligados à temática.

- Desenvolver em parceria com a ESMAT Manual da Institucionalização da Gestão Socioambiental para exposição aos servidores e jurisdicionados.

O manual é uma maneira de trazer conhecimento aos servidores e jurisdicionados com informações a respeito das normas ligadas à sustentabilidade, instituição e papel do Núcleo de Gestão Socioambiental do TJTO e Comissão Gestora do PLS, abordar sobre A3P, PLS e seus resultados, dando publicidade por meio de 
disponibilização no site do TJTO, enviando por e-mail aos servidores e se possível realizar a impressão gráfica.

- $\quad$ Promover junto com a Diretoria da Comunicação Social, vídeos curtos com informações sobre a temática.

Os vídeos podem ser disponibilizados no site do TJTO, estabelecendo um canal com a sociedade e enviados aos servidores.

- Criar por meio da Diretoria de Informática e Tecnologia página própria do Núcleo de Gestão Socioambiental ou link próprio no site do TJTO;

Uma página exclusiva para o Núcleo de Gestão Socioambiental na rede permitirá condensar informações, dar publicidade dos atos, veicular os vídeos, expor o manual, dentre outras possibilidades.

- Instituir por meio de Resolução a Semana Integrada do Meio Ambiente, a ser promovida pelo Núcleo de Gestão Socioambiental em parceria com a Escola Superior da Magistratura, com o objetivo de promover sensibilização/conscientização dos servidores e jurisdicionados a respeito de assuntos ligados à sustentabilidade, por meio de ações como: stand na sede do Tribunal de Justiça chamando a atenção de todos para a temática com entrega de material que tragam esclarecimento/notícias sobre o assunto, palestras/cursos, notícias/vídeos temáticas enviadas por e-mail, ferramenta SEI e Zap Justiça. Cujo objetivo seja envolver todo o Tribunal nas ações desenvolvidas, chamando a atenção para a temática.

Sugere-se que a intensificação das ações em uma semana do ano, coincida com a semana da publicação dos relatórios do PLS possibilitando divulgar e dar ênfase aos resultados obtidos, o que permitirá o processo contínuo referente à sensibilização.

- Desenvolver campanhas que auxiliam na diminuição dos gastos com energia elétrica, água, combustível, copo descartáveis.

Orientações adequadas que promovam a reafirmação de políticas de mudanças de hábitos relacionadas às ações para redução do consumo, através de banners, avisos, para o uso correto do bem natural do material utilizado.

- $\quad$ Editar Instrução Normativa que regulamente o descarte de resíduos recicláveis e orgânicos no âmbito do TJTO;

Estabelecer as normas procedimentais para a separação e descarte dos resíduos e a forma da sua coleta. Como parâmetro indicamos a IN nº. 11/2018 do TRE/PR. 
- $\quad$ Celebrar Termo de Cooperação Técnica com entidades que realizam o reaproveitamento de materiais recicláveis;

As parceiras com os catadores de materiais recicláveis possibilita a destinação correta dos resíduos gerados, visando à diminuição da produção residual.

- Instituir por meio de Resolução a Política Institucional da Sustentabilidade do TJTO, visando o desenvolvimento sustentável da Instituição;

Com a instituição da resolução a política de sustentabilidade passa a ser de observância obrigatória por todos os servidores, visto que será instituída a aplicação do normativo aos diversos processos de trabalho, projetos e planos de ação do Tribunal. Recomendamos como parâmetro a Resolução nº. 807/2018 do TRE/PR. 